THE ROLE OF UNIVERSITIES IN CORPORATE

CONTRACT TRAINING AND DEVELOPMENT

\author{
A Dissertation \\ Presented to \\ The Faculty of the Curry School of Education \\ University of Virginia \\ In Partial Fulfillment \\ of the Requirements for the Degree \\ Doctor of Education
}

by

Donald A. Hasseltine, BA, MA

August 2000 
(C) Copyright by Donald A Hasseltine

All Rights Reserved

August 2000 


\begin{abstract}
The current economic transformation from an industrial- to an information economy requires that workers achieve an increasingly higher level of formal education and pursue on-going, continuous training and development throughout their careers. This in turn has created an ever-increasing demand for workforce development and training services. Local, state, and federal governments and the business community are searching for partners to help address the business sector demand for training services. The business community and government sector are pressuring higher education to play a larger role, especially since universities possess the important catalysts of the information economy, technology development, knowledge and human resource development, and have an infrastructure to provide training services. Seventy-five percent of community colleges were found to be participating in contract training, however, universities have remained equivocal about their involvement in economic development initiatives. This descriptive study was designed to examine what role, if any, universities were playing in providing training and development services to business and industry. To gain the broadest and most comprehensive view, this study analyzed this issue from a university continuing education unit perspective. The purpose of the study was to improve the understanding of what kind, to whom, and how often university continuing education units were providing corporate training services. The barriers and benefits were also included in the study. Seventeen research questions were developed to examine this issue. 195 of 236 doctoralgranting institutions were identified as having centralized continuing education units and were asked to complete a 31-item survey regarding their involvement in corporate training and development. 111 completed and returned the survey, for a participation rate of 56 percent. The findings were presented in tabular and narrative formats. Institutional comparisons of findings were conducted based on type, enrollment size, Carnegie classification, and geographic location. This study found that university continuing education units were viable and active providers of contract training, especially large public universities, located in urban areas. Seventy-five percent of respondents reported supporting a contract training program. This study found that contract training programs provide revenue, enhance internal and external visibility, and improve the university business relationship with the business community.
\end{abstract}


To my wife, Rebecca

For your love, support, patience, and understanding throughout this project. 


\section{ACKNOWLEDGMENTS}

The following recognition of people only touches the surface of the many individuals who contributed in one way or another to the success of this project. To all of you who encouraged, read, and counseled me along the way, I am most grateful for your support. There are several people, however, who deserve special mention here.

I want to thank my dissertation committee of Alton Taylor, Chair, Robert Covert, James Clawson, and Patricia Lampkin for their expert advice, guidance, encouragement, and support. I want to extent a special acknowledgement to Dr. Taylor for supporting me and this project during the early- stages when there was some question whether this project would ever get its legs.

To my graduate school colleagues: Gene Crume, Ben Boggs, Steve Titus, and Bill Haarlow for their friendship, encouragement, and intellectual discourse.

To my mom, Jean, and my late father, Ron, for their love and for instilling in me the will to succeed. This project required all of the perseverance and personal discipline that I could muster. It was the early life lessons that were learned at home that helped me see this project to its conclusion.

To my colleagues at Colby-Sawyer, especially Debra Taylor, Susan Kraeger, and Anne Ponder, for their editing and proofreading skills and for cheering me on.

To Theodore Settle and Jennings Wagoner, for caring about this project and my well-being. They both made unique and significant contributions to the success of this project that I will be forever grateful. 


\section{TABLE OF CONTENTS}

Chapter

Page

1. OVERVIEW OF THE STUDY

Introduction

Statement of the Problem

Purpose of Study

Research Questions

Definition of Terms

Methodology

Expected Outcomes

2. REVIEW OF THE LITERATURE

The Involvement of Higher Education in Economic and Workforce Development

Corporate Training Practices and the Economic Forces Influencing the Demand for Training and Development

Partnerships between Business and Higher Education

Research Studies on Business/Higher Education Training Partnerships

Conclusion

3. METHODOLOGY 57

Introduction

Research Questions

Population and Sample

Instrument Development

Administration of the Instrument

Data Processing and Analysis

Study Limitations

4. PRESENTATION AND ANALYSIS OF DATA 66

Introduction

Demographic Profile

The Research Questions

Summary of Findings to the Research Questions

Profile Comparisons 
5. DISCUSSION AND RECOMMENDATIONS

Introduction

Discussion

Conclusions

Recommendations for Future Research
A. Corporate Contract Training Survey
B. Operational Table
C. Personalized Survey Letter
D. Follow up Survey Letter and Email
E. Participating Institutions and Non-Participating Institutions
F. Letter Inviting Pilot Study Participants
G. Workforce Development Survey Comments

vii. 
Education, Leadership, Foundation and Policy

\author{
Curry School of Education \\ University of Virginia \\ Charlottesville, Virginia
}

\title{
APPROVAL OF DISSERTATION
}

This dissertation proposal, The Role of Universities in Corporate Contract Training and Development, has been approved by the graduate faculty of the Curry School of Education in partial fulfillment of the requirements for the Degree of Doctor of Education.

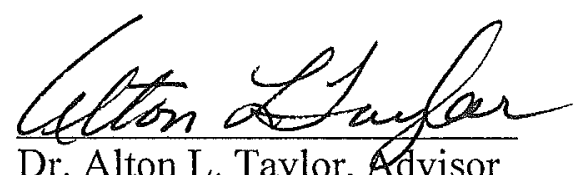

Dr. Alton L. Taylor, Aavisor

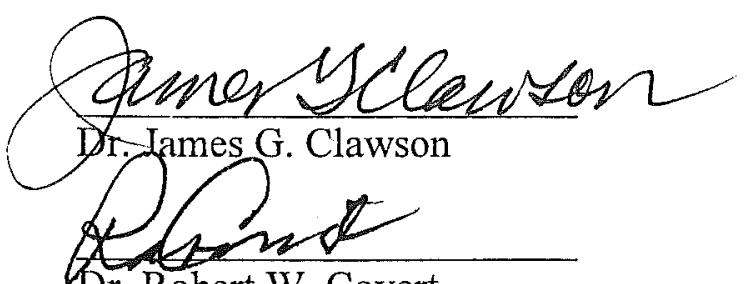

Dr. Robert W. Covert

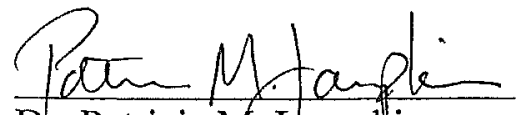

Dr. Patricia M. Lampllin

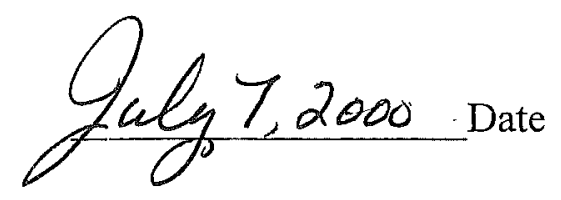




\section{List of Tables}

Table 1: An Analysis of the Survey Participants

Based on Demographics

Table 2: Continuing Education Units Organizational Characteristics.......... 69

Table 3: The Extent to which Corporate Training is Part of the Continuing Education Units' Mission

Table 4: The Extent to which Universities Provide

Financial Support to Continuing Education Units

for Contract Training

Table 5: The Extent to which Continuing Education

Units Staff Their Contract Training Programs

Table 6: The Number of Corporate Training Programs

Contracted Each Year by Continuing Education Units

Table 7: The Geographic Location of Continuing Education

Units' Corporate Training Programs

Table 8: The Estimated Number of Enrollees in

Continuing Education Units' Corporate Contract

Training Programs

Table 9: Revenue for Continuing Education Units'

Corporate Training Programs

Table 10: The Extent to which Continuing Education

Units are Increasing or Decreasing Their Involvement

in Contract Training

Table 11: A Measure of Continuing Education Units'

Satisfaction with Their Contract Training Programs

Table 12: Types of Training Offered by Continuing Education Units

Table 13: Contract Training Programs in Most Demand

from Continuing Education Units

Table 14: The Level of Employee Continuing Education

Contract Training Programs are Serving 
Table 15: The Size of Company Seeking Continuing

Education Units' Contract Training Services

Table 16: The Business Sectors Served by Continuing

Education Units' Contract Training Programs

Table 17: Institutional Benefits Derived from

Continuing Education Contract Training Programs

Table 18: Identified Barriers to Delivering Contract Training

Table 19: Characteristics of Successful Continuing

Education Contract Training Programs to Business and Industry

Table 20: Demographic Comparison Public and

Private University Contract Training Programs

Table 21: Comparison Public and

Private University Contract Training Programs

Table 22: Demographic Comparison of Contract Training Programs

based on Enrollment Size

Table 23: Comparison of Contract Training Programs

based on Enrollment Size

Table 24: Demographic Comparison of Contract Training Programs

based on Carnegie classification

Table 25: Comparison of Contract Training Programs

based on Carnegie classification

Table 26: Demographic Comparison of Contract Training Programs based on Location

Table 27: Comparison of Contract Training Programs based on Location 


\section{CHAPTER ONE}

\section{OVERVIEW OF THE STUDY}

\section{Introduction}

Rapidly changing technology, shifting demographics, and the growing importance of human capital characterize the American economy of the new millennium. These factors require workers to achieve an increasingly higher level of formal education and to pursue on-going, continuous training and development throughout their careers. Federal and state agencies, the business and education communities are working together to find ways to meet the growing demand for both education and training. Gaining a clearer understanding of who provides training services; how much training is needed; what type of training is needed; and what sectors of business need training services provide businesses, state and federal governments with valuable information regarding how to build effective strategies and policies to support the increasing need to train and educate the workforce. This study explored one facet of this very large and complex issue. Specifically, what role are colleges and universities playing in providing training and development services to the business community.

Throughout the last century, higher education has worked closely with state and federal government leaders to provide the appropriate and necessary education and training for the American workforce. Higher education institutions, for example, trained and educated the managers and executives for the shift from an agrarian to an industrial age economy. After World War II, higher education institutions expanded rapidly to educate and train the mass influx of veterans for an industrialized economy. Now, as the 
economy shifts again, from an industrial to an information economy, colleges and universities find themselves challenged to respond to new demands.

The current economic forces, especially the influence of technology, challenge higher education institutions to intensify their mission in the retraining and education of the adult workforce. Boyer and Hechinger (1981) state: "[Higher education] has an inescapable responsibility to transmit knowledge that would be useful, not merely in the classical sense of preparing [young people], but for the practical demands of a changing world" (p. 5). Chmura (1986) remarked:

In today's economy universities encounter pressure to play a more active role in the economic development of the nation's cities, states, and regions. Their knowledge-based resources now constitute an essential element in the new economic infrastructure that the nation needs to compete in a highly competitive, technologically advanced, and rapidly changing global economy (p. vii).

The corporate sector, needing to stay competitive in the information economy, now seeks providers of on-going continuous training in such areas as technology, management, and communications (U. S. Department of Labor, Bureau of Labor Statistics [BLS], 1996, July 10). Curriculum offerings at most colleges and universities include courses in these areas. They also support continuing education units and graduate schools that are capable of delivering these courses to the corporate community. Yet, most institutions have a mixed view of the importance of their role in economic and workforce development. The governing structure of universities, conflicting priorities of faculty and administrators, and inconsistent state government economic policies make building consensus on issues related to economic and workforce development difficult (Fairweather, 1988; Powers, et al., 1988). Further, some higher educators would question whether training and development is a function central to the mission of the university. 
The literature suggests that colleges and universities remain equivocal about how to respond to corporate executives' calls for increased involvement in economic and workforce development (Aslanian, 1988; Davis and Botkin, 1994). The economies at the federal, state, and local levels are relying on these two institutions to develop a competent and productive workforce. The dearth of research in this area limits the understanding of how business and higher education can work together.

\section{Statement of the Problem}

As changing economic, demographic, and workplace factors converge to create an ever-increasing demand for workforce development and training, further research appears necessary to understand the role of each provider, whether business, governmental, private, or educational. Lynch states: "In spite of the importance of this issue, serious gaps exist in our knowledge of such fundamental questions as how much training takes place, who provides it, and who gets it'(Lynch, 1995, p.1). Colleges and universities are positioned uniquely to participate, with state and federal governments and the business community, in preparing the American workforce for the $21^{\text {st }}$ century. Yet, little is known about their role in workforce training and development.

Community colleges' involvement in economic and workforce development has been well documented (Anderson, 1995; Ash, 1989; Ball, 1994; Ballantyne, 1985; Beder, 1984; Collier, 1996; Gerlach, 1992; Gexler, 1994; Gladden, 1988; Henderson, 1986; Lawrence, 1997; Lusk, 1987; Wakefield, 1992; Wigginton, 1996; Wilder, 1988; WolinDeluca, 1991). No one, however, has explored the role of colleges and universities in corporate training and development. To begin addressing this gap, this project focused 
on university continuing education unit's role in providing re-education and training services to the corporate sector. Approaching the research from this perspective yielded the broadest and most comprehensive view of how institutions were participating in this phenomenon. This study also provided important information concerning how universities were responding to the rapidly changing workforce needs of the business community.

\section{Purpose of Study}

The purpose of this descriptive study was to improve the understanding of what kind, to whom, and how often universities continuing education units were providing corporate training services. The barriers and the benefits of offering contract training programs to business and industry were also included in this research.

\section{Research Questions}

Seventeen research questions were developed to examine business/higher education training partnerships:

1. Are corporate workforce development activities an accepted part of the continuing education units' mission?

2. What financial support does the university provide for corporate training programs (i.e., are corporate workforce development programs expected to be self-sufficient)?

3. How many staff members are dedicated to corporate contract training activities?

4. How many corporate contract training programs are offered each year by continuing education units?

5. Are continuing education units' corporate training programs serving local, regional, national, and international interests? 
6. What was the 1998 enrollment in continuing education sponsored corporate contract training?

7. How much revenue do corporate training programs produce?

8. Are continuing education units increasing or decreasing their involvement in contract training?

9. Are continuing education units satisfied with their corporate contract training programs?

10. What types of corporate training programs do continuing education units offer?

11. What type of training does business and industry most commonly request?

12. What level of employee do continuing education units' contract training programs most often serve?

13. What size companies are seeking corporate contract training services?

14. What types of businesses are seeking contract training services from continuing education units?

15. What university benefits are derived from offering contract training programs to business and industry?

16. What problems and barriers limit universities from providing corporate contract training programs?

17. What characteristics facilitate effective corporate contract training programs between business and higher education? 


\section{Definition of Terms}

Business, Business and Industry, Business Sector, Corporate Sector are synonymous terms, meaning a commercial enterprise for making a profit (Collier, 1996).

Carnegie Classifications is a categorization of colleges and universities created by the Carnegie Foundation for the Advancement of Teaching. The classifications are based on programs offered, at what level, and the dollar level of research funding from the federal government. For example: "Research I institutions offer a full range of baccalaureate programs, are committed to graduate education through the doctorate, and give high priority to research. In addition, they receive annually $\$ 40$ million or more in federal support" (Carnegie Foundation for the Advancement of Teaching, 1994, p. xix).

Contract Training is ".. an arrangement in which an organization, whether a business, a government agency, or volunteer association, contracts directly with a college for instruction of its employees, its clients, or its members" (Alsanian, 1988, p. 243).

College and University refer to four-year accredited postsecondary institutions. For the purposes of this study, references to higher education, unless otherwise specified, are to colleges and universities only. The primary focus of this study, however, is on universities. This type of institution offers undergraduate and graduate programs and has a mission that includes teaching, research, and service.

Community Colleges are defined as two-year accredited postsecondary institutions that offer Associate of Arts or Associate of Science degrees (Cohen and Brawer, 1989).

Continuing Education is the formal process by which adults continue to learn new skills, explore academic interests, and continue their professional development. 
Organized and comprehensive programs may include formal/informal discussion groups and meetings, educational programs, credit and non-credit courses, and certificate courses and programs (Cervero and Scanlan, 1985).

Corporate Contract Training Programs are training programs offered by outside vendors to business and industry. This type of training comes in a variety of formats, including credit and non-credit courses, degree programs, workshops, and seminars.

Economic Development is a process of innovation that increases the capacity of individuals and organizations to produce goods and services, thereby creating wealth. Federal, state, and local governments rely on economic development policies to increase productivity, create employment opportunities, increase employee income potential, and improve the employee's quality of life (Chmura, 1986). Such policies usually start with building an effective and productive workforce.

Formal Training is planned training that has a structured format and defined curriculum (BLS, 1996, December 19). Contract training is categorized under this heading.

Human Capital refers to what workers bring to a job besides their physical presence, such as energy, motivation, skills, and knowledge, which can be harnessed over a period of time to the task of producing goods and services (Cross and McCartan, 1984).

Information Economy is described as a shift from products to services, from physical resources to human resources, from investment in machinery to investment in knowledge, from capital intensity to knowledge intensity, and from a domestic economy to a global economy (Cross and McCartan, 1984, p.90). 
Informal Training is learning that is unstructured, unplanned, and easily adapted to situations or individuals (BLS, 1996, December 19).

Role is defined as the workforce development functions continuing education provides to business and industry.

Training and Workforce Development are those activities, informal or formal, designed to improve on-the-job performance or enable a learner to acquire a new skill. These terms are used interchangeably for this study and reference formal training conducted for business and industry unless otherwise stated (Collier, 1996).

\section{Methodology}

The population for this descriptive study was 236 Carnegie classified doctoralgranting universities. These institutions were purposefully selected, because they support continuing education at a higher rate $(90 \%+)$ than the national average $(72 \%)$ (Shoemaker, 1998). Doctoral-granting universities have also built more collaborative relationships with the business community than other types of higher education institutions (Powers, et al., 1988). This research was conducted with the director of continuing education or a pre-identified administrator who handles corporate workforce contracts. A 31-item questionnaire was constructed (see Appendix A) based on the findings in the business/higher education partnership literature, interviews with continuing education leaders, and counsel from four University of Virginia faculty members. The survey was used to gather information to identify what kind, to whom, and how often universities were providing corporate training services and to determine the benefits and barriers of offering contract training programs to business and industry. A pilot study was conducted with five continuing education professionals to achieve a 
high level of face and content validity. The survey was mailed to the director of continuing education or the individual that oversees contract training program. A Microsoft Excel spreadsheet was constructed to manage and process the responses. Frequencies, means, and percentages were used to analyze the data. The findings were presented in tabular and narrative formats. Institutional comparisons of findings were conducted based on type, enrollment size, Carnegie classification, and geographic location.

\section{Expected Outcomes}

The researcher expected to obtain valuable information regarding the contract training programs offered by university continuing education units to the business community. This included discovering how much, what kind, where, and to whom contract training was offered. The benefits, barriers, and success characteristics of contract training partnerships were also identified in this study. Comparisons based on institutional demographic data allowed the researcher to develop profiles of various subsamples that identified different levels of involvement and support for corporate contract training.

This study expected to yield information for policy makers and university administrators to include in developing policies regarding what role colleges and universities should assume in dèlivering corporate training and development programs to business and industry. The business community should gain an understanding that colleges and universities provide a variety of training services to many types of businesses and workers. Lastly, this study expected to provide the research community 
with important insights into the unique role universities plays in meeting corporate training needs.

\section{Preview of Forthcoming Chapters}

The literature pertaining to the role of higher education in economic and workforce development will be summarized in the second chapter. Then, in the third chapter, the study population and samples will be discussed, as well as the construction and administration of the study instrument and the data analysis employed. Data pertaining to each of the research questions and the sub-sample comparisons will be discussed in the fourth chapter. The final chapter will summarize the study, discuss the findings, and provide recommendations for further research. 


\section{CHAPTER TWO}

\section{LITERATURE REVIEW}

\section{Introduction}

For the purposes of this study, there were several bodies of literature to consider. First, it was important to explore the economic forces that were increasing the demand for corporate training and development. Second, higher education's past and present involvement in economic and workforce development is examined. This section also includes a review of university continuing education involvement in training and development and explores state governments' current view of higher education's role in economic development. Third, current business-training practices are reviewed. Lastly, business/higher education partnerships and research studies on business/higher education training partnerships are explored. This chronology provides the context and support for researching the role of universities as providers of corporate training and development.

\section{The Economic Forces Influencing the Demand for Training and Development}

The rapid change in technology, a move to an information economy, globalization, and shifting demographics are changing how companies are organized, how work is done, and the skills required to be successful (Aslanian, 1988; Eurich, 1989; Fairweather, 1988; Tyson, 1987). The industrial age corporate organization, based on military principles with the decision-makers at the top and the doers at the bottom, is no longer an effective model for the current information economy. Organizations have broadened workers' roles, flattened the organizational structure, downsized their 
workforce, and incorporated a more diverse, flexible, and mobile labor force. Company executives have found that these changes require people who can effectively use modern technology, work with diverse groups, and “... solve problems, exercise judgment, learn new skills and knowledge throughout a lifetime" (Gordon, Morgan, and Ponticell, 1994, p. 143). Drucker (1994) and others describe these new personnel as "knowledge workers". The evolving corporate landscape makes re-education and training an increasingly important element of corporate success.

As corporations have adapted to the information economy, the demand for information technology workers has increased exponentially. Employment in the computer and software industries has almost tripled in the last decade (U.S. Department of Commerce, Office of Technology Policy, 1997, p.20). The growth has created demand for workers across industries including manufacturing, service, transportation, healthcare, education, and government. Approximately 346,000 technical jobs went unfilled in 1997. In a 1997 Information Technology Association of America survey, 50 percent of corporate heads cited the lack of skilled/trained workers as the "most significant barrier" to their growth in the next year. This problem was viewed more significantly than other economic conditions such as profitability, lack of capital investments, taxes, or government regulation. Further, as computer-based information systems have become an indispensable part of managing information, workflow, and transactions in both the public and private sector, a shortage of information technologist affects directly the ability to develop and implement new systems (Frazis, Gittleman, and Joyce, 1998). These information systems increase worker productivity, create economic efficiencies, and produce profits for the private sector. The inability to meet the demand 
for information technologist could hamper America's competitiveness, economic growth, and job creation.

In addition, the Bureau of Labor Statistics reported that over the next decade management, professional, and technical occupations are expected to be among the fastest growing occupations (Brown, 1995). These workers are most likely to receive and need on-going training to become productive "knowledge" workers. Companies will need to commit increasingly more resources to training and development to compete in the global marketplace.

Economic globalization draws regional, national, and international markets closer together. This creates an opportunity to redistribute the low and high skilled labor force. Because technology eliminates time and space, businesses can move low-skill jobs to countries that pay the lowest wages, and unilaterally, to move high-skill, high-wage jobs to countries most able to produce well-trained workers. This type of efficiency lowers production costs and generates more profits for companies. Countries and businesses able to develop these labor force efficiencies and increase the productivity of high-skilled workers through knowledge and skill development will enjoy a competitive advantage and economic prosperity (Ball, 1994; Drucker, 1994; Fairweather, 1988).

As technology and globalization are dramatically influencing workers and the working environment, the business sector is also confronting shifting demographics in the labor force. The demographic shift to an older, more diverse, labor force that has fewer white male entrants each year affects training demand. In 1976, workers 16-34 comprised half of the civilian workforce. By 2006, workers 34-64 will account for 63 percent of the labor force (U. S. Department of Labor, Bureau of Labor Statistics, 1997). 
The composition of the labor is changing too. By 2006, non-whites will comprise 23 percent of the workforce, compared to 21 percent in 1995 . Women will account for 50 percent of the new entrants into the labor force by 2006 . White men, who currently constitute 47 percent of the labor force, will account for just 15 percent of the new entrants (Brown, 1990). In states such as California, the shifts are expected to be even more dramatic. Researchers predict that in one generation, the California population will shift from 91 percent Caucasian to 70 percent minority. One in four people will be 65 and older by the year 2030 (Tyson, 1987). Despite these trends, Caucasians, who make up 86 percent of the workforce, currently receive 92 percent of the formal training. Blacks and Hispanics, who constitute 10 percent and 5 percent of the workforce, receive 5 percent and 3 percent of the formal training respectively (Brown, 1990). With a smaller cohort entering the workforce, those already in the labor force will also need to adapt to the changing needs of a highly competitive, global economy (Gehres III, 1998). The shifting demographics in the labor force, combined with increasing need for skilled workers in the service and technology sectors, support the growing need for training and development services.

The public and private sectors are striving to stay ahead of the external economic forces by spending nearly as much on employee training and development each year as is spent on all of elementary, secondary, and higher education combined. American employers in 1990 spent an estimated $\$ 210$ billion for training and development $(\$ 180$ billion for informal training and $\$ 30$ billion for formal training) compared to $\$ 250$ billion expended on K-12 and higher education (Burton, 1992). In a more recent assessment, Frazis, Gittleman, and Joyce (1998) reported that employers of 50 or more employees 
spent roughly $\$ 66$ billion in 1994 . The breakdown of these expenditures included $\$ 7.7$ billion on in-house trainers, $\$ 5.5$ billion to outside vendors, and $\$ 2.8$ billion on tuition reimbursements. Another $\$ 37$ billion was spent on indirect wage and salary costs of training and $\$ 13$ billion for time spent in formal training (Frazis, et. al, 1998, p.8).

Although this investment appears to be significant, the perception from both the public policy arena and private sector is that the United States has under invested in training, especially compared to Germany and Japan (Lynch and Black, 1996). Some speculate that more resources are not designated for training and development because, as former Labor Secretary Ray Marshall remarked, "Human development is unpredictable. We know that human capital investment works. But we don't understand what we know" (Carnevale and Johnston, 1989, p. 47). Despite the corporate investment in training, the inability to measure the training outcomes prevents employers from investing even more resources into workforce development.

Business and industry leaders currently depend upon a system of school-based learning, combined with formal and informal training on the job, as the foundation for productive capacity and performance (Drucker 1978; Lynch and Black, 1996). With fewer entrants coming into the labor force, companies now routinely retrain employees to fill jobs created by new technologies and keep workers current (Ball, 1994). The changing nature of work through adoption of new processes, procedures, systems, techniques, equipment, or practices makes training an ongoing, continuous process (Powers, et al., 1988).

Providing the necessary re-education and training to the labor force in the decade ahead will be essential to the economic vitality of the country. Developing a workable 
organizational structure and finding the resources to meet this challenge requires an understanding of how the public and private sectors will work together on this problem. This includes a clearer understanding of higher education's participation.

\section{The Involvement of Higher Education in Economic and Workforce Development}

Since the late 1800 s, higher education has actively responded to economic and workforce development needs. In the late nineteenth century as part of the Morrill Act of 1865, colleges and universities provided much of the management and technical training to move the United States from an agricultural-based to an industrial-based economy (Veysey, 1965). Botkin, Dimancesus, and Strata suggest that "perhaps the most impressive legacy born of the Morrill Act was the understanding that education, open to all and focused on learning, applied to real economic needs and could not be divorced from economic growth and national strategy" (Matthews and Norgoard, 1984, p. 153). Higher education's economic role continued to expand with the growth of industrialization and two World Wars. After World War II, American colleges educated and trained veterans for their re-entry into the workforce. The GI Bill that supported veterans participation in higher education also spawned the dramatic growth of individuals seeking higher education, and permanently linked higher education to individual economic success. In the 1960s and 1970s, federally sponsored financial aid programs continued to increase student access and provided colleges and universities with the means to meet society's growing need for professional and technical workers. Today, higher education collaborates with federal and state agencies to provide much of the formal education and technical training for entrants into the labor force. Higher 
education's responsiveness to economic and workforce-related demands has provided one of the essential ingredients for America's economic prosperity over the last century.

Despite a long history of collaboration and the ongoing interest of the federal government, business/higher education partnerships grew gradually until the late 1970s. The onset of the information economy, technology, and globalization has sparked an increased interest in building collaborative relationships between the business community and higher education. Academic leaders searching for new revenues; industrialists looking for a renewed competitive edge through research, information, and technology; and state and federal governments attempting to restore economic vitality have also inspired a renewed advocacy for business/higher education partnerships (Fairweather, 1988).

As the American economy has evolved, the need for formal education has grown dramatically. The enormous increase in school attendance at various levels over the last hundred years exemplifies this change (Lynton, 1984). From 1870 to 1940, high school attendance rose by a factor of thirty, from 0.7 to 22 percent. From 1940-1980, enrollment in postsecondary education rose from 1.5 million to 11.5 million. The number of enrolled 18-24 year olds also increased from 10 to 40 percent. From 1971-1997, the number of Americans with a college degree grew from 12 million to 41 million (Digest of Educational Statistics, 1997). The demand for postsecondary education continues to grow, and society's expectation of higher education to provide affordable, quality educational opportunities with universal access has risen proportionately with these demands (Kerr, 1994). 
Higher education is currently feeling the pressure to participate in economic development from many sides (Chmura, 1986). Society wants higher education to produce a better return from limited public funds. State governments want jobs for residents, an influx of new firms, an increasing tax base, and data and analytical support. Industry wants a skilled and effective workforce and access to top faculty and resources. The local community wants jobs for residents, good town/gown relationships, and good local economic development. These pressures are forcing higher education to re-think their mission in a broader economic context.

Many internal and external factors, however, influence an institution's decision to participate in economic development. The most important factor appears to be dynamic, entrepreneurial leadership (Chmura, 1986). Other essential factors include institutional capacity, strong relations with the public and private sectors, a supportive campus culture, availability of special resources, supportive administrative policies, and special organizational arrangements. Yet, the higher education organizational structure often lacks the flexibility to support the creation of these arrangements. Institutional governance, for example, is a bifurcated system for the faculty and administration, making cross over issues such as economic development difficult to resolve. How to make university knowledge and services available for economic development purposes appears to be a major challenge for public colleges and universities and state governments interested in their support.

The business sector, in particular, has sought increasingly more assistance from higher education to provide training and development services (Peterson and Dill, 1997). The desire for markets and academics to interweave in this way is a recent phenomenon. 
Until a decade ago, colleges and universities educated young adults and large organizations hired them. Businesses relied primarily on in-house training programs. The separation of education and training worked, because the labor market was much more segmented than it is today (Valentine, 1997). Information technology, however, has eliminated the barriers separating labor markets, institutions, and society. This environment supports the increased interest in higher education/business partnerships, especially for employee training and development.

Stanford Research Institute (SRI), a policy think tank, suggests that the appropriate role for colleges and universities in economic and workforce development is the strategic use of knowledge-based resources that assist the growth of local, regional, or state economies (Chmura, 1986). Universities have the capacity to produce goods and services, jobs, and tax dollars for their community and state through the development of research parks, faculty/business exchanges, and collaborative corporate training programs. Institutions that participate in this type of economic development find that these programs fit within the traditional university missions of research, teaching, and service (Fairweather, 1988).

The American Council on Education (ACE) and the University Continuing Education Association (UCEA) are conducting research to examine higher education's role in economic development. ACE has recently completed a pilot study to identify the types and number of partnerships that exist among four-year institutions and industry. UCEA has developed a Commission on Workforce Development and defined building "external alliances" as a 1998-research priority. 
The current federal government has also invested additional resources into postsecondary education and labor force training programs. Some of these initiatives have included: developing the Hope Scholarship program, expanding the Pell Grant allocation, introducing new tax deductions for college and lifelong learning, and budgeting millions of dollars for the 1998 Workforce Investment Act (Workforce Investment Act, 1998). In addition, federal agencies such as the Departments of Agriculture, Commerce, Education, and Labor have opened a dialogue with their respective constituencies on workforce-related issues. National leaders from the business, labor, education, and government sectors are also working together to design a coordinated and collaborative workforce development action plan (Gore Summit, 1999).

The interest of federal and state governments and the higher education community demonstrates the high level of concern regarding the future strength of the American workforce. The major commitment by these organizations suggests that business/higher education partnerships deserve a higher level of attention by the higher education research community.

\section{The Linking of State Governments, Economic Development, and Higher Education}

Economic development, once the domain of the federal government, has increasingly become an important state issue. This shift stems from a desire to balance budgets, reduce unemployment, and attract high-tech businesses (Cross and McCartan, 1984). Economic development on the state level is influenced by several factors including the ability of industry to restructure; entrepreneurial approaches; availability of venture capital; and the quality of worker education and training (Powers, et al., 1988). 
Since higher education is a major contributor of three of the four primary components of the information economy infrastructure-technology development, human resource development, and knowledge — industry, state governments and local communities want public colleges and universities to become more involved in economic development (Chmura, 1986). For example, the Virginia Business and Higher Education Council, a group of respected business leaders, recommended to the governor and legislature of Virginia that higher education's number one priority for the next decade should be to improve Virginia's workforce (Virginia First 2000, 1997). In a 1998 survey, the Education Commission of the States found that 77 percent of all governors agree that higher education should be required to collaborate with business and industry in developing relevant curricula. "Higher education needs to be more accountable than they are now ... about making sure the system meets the state's workforce needs" (Schmidt, 1998, A38). States view higher education as a vehicle to attract new businesses by generating new ideas from university research and providing a talented labor force for businesses interested in relocating to their states (Cross and McCartan, 1984). Pressure from state governments and business community leaders are likely to continue and suggest a broader role for colleges and universities in workforce development and training.

Public colleges and universities can support state economic development initiatives in a variety of ways including economic research and analysis, capacity building for economic development, development of human resources, technical assistance, transfer of technology to industry, basic and applied research on new products and production processes, and stimulate entrepeneurship and new business development 
(Chmura, 1986). The human capital and technology needed by states and communities to compete in today's economy depends heavily on the programs and resources of colleges and universities.

Stevens (1992) warned, however, that a state's economic policy on workforce development is dynamic and shaped by several factors:

1) The observed quality of a state's adult workforce at any point in time is the cumulative result of many decisions made at different times by individuals and groups whose agendas are too diverse to be brought comfortably under a strategic action umbrella;

2) Both predictable events (e.g. election and sunshine provisions in state laws) and unpredictable events (e.g. technological breakthroughs) result in a constant reshuffling of state opportunities and requirements to maintain and enhance adult workforce quality;

3) Government and legislators will continue to create new programs and to redefine executive agency responsibilities;

4) Most of the forces that affect the quality of a state's adult workforce do not arise from explicit intentions to broaden employment opportunities (Stevens, 1992, p. 2).

These factors make state government priorities on workforce development uncertain, which has made higher education reluctant to participant in economic development initiatives. Nevertheless, public institutions of higher education depend heavily on public funding and have an obligation to contribute to economic and social problem solving (Chmura, 1986). The state's ability to link higher education funding to economic development activity will also encourage both groups to build partnerships on economic development issues.

The current economic conditions and a historic precedent suggest that colleges and universities are capable and willing to assume a significant role in the training and development of the American workforce. Universities and other types of institutions of 
higher education possess many of the important economic components to achieving individual and organizational success in the information economy. According to Zemsky and Oedel (1994):

Public universities [are] in the best position to serve the non-traditional, working student who will seek access to low-cost educational outlets. In addition, major employers will want to take advantage of available public subsidies. Lastly, state governments are likely to invest in distance-learning centers to serve the work-connected learner. A public system of higher education, if perceived as providing a multi-site, integrated, and fully transferable set of education opportunities, will enjoy a substantial advantage in this market" (p. 10).

Consequently, corporate and governmental agencies will continue to seek higher education's support for their economic and workforce development initiatives.

\section{University Continuing Education Serves the Corporate Community}

For this study, examining higher education's role in training and development from the continuing education prospective provided the broadest and most comprehensive view of doctoral-granting institutions participation. Continuing education remains the only centralized function within a university whose primary mission is to serve the external community and the market place. Universities are actively involved in post-graduate and professional re-education, especially graduate schools of business, medicine, and engineering. Focusing specifically on graduate-based training programs, however, would have limited the type, scope, and depth of the data and would have confined the generalizability of the findings to only one discipline. Since little data have been collected and analyzed concerning higher education's role, a broader assessment of their involvement in corporate training was necessary.

Divisions of continuing education were created to serve community academic interests outside of the traditional university graduate and undergraduate offerings. The 
beginning of continuing education at colleges and universities is linked to the county extension efforts of the early land-grant colleges such as Cornell University. Most state institutions supported these initiatives by the early 1900s (Shoemaker, 1998). One of the first supporters of continuing education was Lawrence Jacks. He envisioned a kind of education based on continuity of learning. At about the same time, educators were beginning to accept that education was a lifelong process, "beginning at birth and ending at death" (Jacks, 1931, p.123). In the 1950s, many institutions of higher education, especially public universities, developed centers of continuing education that provided credit and non-credit courses to adults. Today more than 72 percent of institutions of higher education offer non-credit programs for adults (Shoemaker, 1998). Continuing education programs provide local communities with an important educational service and contribute to the overall quality of life in those areas.

Shoemaker (1998) described the mission and importance of continuing education to the community and the institution:

Community and regional outreach has always been and remains the primary mission of continuing education programs. The ability of an institution to extend its reputation and credibility for providing high quality, relevant courses and to serve the surrounding population have given millions of adults an opportunity to enhance their lives, meet new professional and personal challenges, and manage their work lives more effectively. These programs give the institution a valuable link to society and the community and provide a balance to the other academic initiatives as a service to their community (p. 9).

The focus of university continuing education has evolved with the needs of the community and the marketplace. Continuing education has expanded to include a wide range of educational formats and curricula, and its roles now include that of problem solver, facilitator, and community-development activator (Brown, 1990, p. iv). Two of continuing education's current priorities are: (1) programs that enhance a student's 
development intellectually and build career abilities as appropriate, and (2) programs that are requested by the community and the marketplace (Shoemaker, 1998). Both priorities support continuing education's interest in providing training and development programs. Shoemaker (1998) suggests that the rate of technological change, global competition, social trends, and the evolving nature of work will increase continuing education's service role.

The information economy, for example, makes education credentials and continuing education increasingly important for increased wages and job security. In the last 25 years, the number of Americans with a college degree has grown from 12 million to 41 million. The percentage of adults pursuing continuing education of some kind grew 25 percent between 1991 and 1995 (Gehres, 1998, p.17). Over 58 percent of adults who participated in continuing education in 1995 had at least a college degree. The University Continuing Education Association (UCEA) also reported that many university continuing education units currently offer corporate training programs, although the size and scope of these programs are unknown. The growth in education credentials, training, and the transformative affects of the information economy suggests that university continuing education units will assume a more significant role in providing all types of programming, including corporate training and development.

\section{Corporate Training Practices}

The following section describes the characteristics of current business and industry training practices including: types of training, business sectors offering training, most common types of training, recipients of training, training providers, outcome of 
training, and future corporate training practices. This section also explores the corporate communities increasing commitment to training and development.

Corporate training can be either an informal or a formal process. Informal training refers to training that occurs on the job without any specific parameters, such as time, content, or outcome. Formal training refers to organized learning for a specific purpose and includes contract training programs.

The Bureau of Labor Statistics defines and categorizes training into the following areas:

- Management training is training in supervising and implementing employment practices. Examples include training in conducting employee appraisals, managing employees, resolving conflicts, and following selection/hiring practices.

- Professional and technical skills training is training in professional areas such as engineering, nursing, accounting, science, law, and medicine.

- Computer procedures, programming, and software training include training in computer literacy; security; programming; use of standard, commercial, and other software, and methods for developing software applications.

- Clerical and administrative support skills training is training in areas such as typing, filing, business correspondence, and administrative record keeping and budgeting.

- Sales and customer services training is training in areas ranging from how to maintain and improve customer relations to specific selling techniques.

- Service-related training includes training in the traditional service occupations such as food, cleaning, and personal services. Examples include training in waiting tables, preparing food, using cleaning equipment, and providing childcare.

- Production and construction related training is training in areas such as operating machinery and equipment, manufacturing, assembling, distributing, installing, or inspecting goods.

- Basic skills training is training in elementary reading, writing, mathematics, and language skills.

- Occupational safety training provides information on safety hazards, procedures, and regulations. 
- Employee health and wellness training provides information and guidance on personal health matters.

- Orientation training introduces new employees to personnel and workplace practices.

- Awareness training provides information on policies and practices that affect employee relations (i.e., sexual harassment policies and cultural diversity).

- Communications, employee development, and quality training includes public speaking, office organization, and time management (BLS, 1996, December 19).

These categories indicate that training can serve a variety of purposes including job specific (i.e., management, clerical), corporate specific (i.e., orientation), personal (i.e., health and wellness), and a combination (i.e., communications). The many types of training illuminate the organizational challenge of trying to find the most effective way to improve an employee's work performance and productivity.

Business sectors that offer training. In 1994, the National Center on the Educational Quality of the Workforce (EQW) and the U. S. Department of Education conducted a nationwide telephone survey of private establishments with 20 or more employees $(\mathrm{N}=2,941)$. The percentages that follow are the frequency in which respondents reported having formal training opportunities for their employees. The EQW study found that utilities (100\%), finance (96\%), insurance (95\%), and communication (94\%) companies were most likely to offer formal training (Lynch and Black, 1996). Companies employing a greater proportion of technically skilled, female, and educated (i.e., completed some college) workers were also more likely to offer formal training. In addition, organizations that used benchmarking, Total Quality Management, and innovative workplace practices were more likely to offer formal training (Frazis, et. al, 1998). Employee assistance plans were also a strong indicator of a companies 
commitment to training, since implicit in this commitment is a want to assist rather than replace employees with difficulties. Service sector companies that were technologically engaged, hire educated women, have innovative management practices, and progressive human resource policies appeared most likely to offer formal training opportunities.

The type, size, and labor force characteristics can inversely affect a company's commitment to offer training opportunities. The business sectors least likely to offer formal training were the textile and apparel, transportation, and fabricated metals industries (Lynch and Black, 1996). Manufacturing companies with 50 or fewer employees and non-manufacturing companies of 100 or fewer employees were less inclined to offer formal training. Companies with high turnover rates, a high proportion of part-time workers, and the presence of labor unions reduced the likelihood of formaltraining opportunities (Frazis, et. al, 1998). Smaller manufacturing type businesses, with volatile turnover rates, and a high percentage of part-time workers were least likely to risk resources on formal training opportunities.

Most common types of training. A U. S. Training, Census, and Trends Report identified supervisory skills (77.1\%), new employee orientation (71.2\%), management skills and development (67.3\%), communication skills (58.3\%), and technical skills $(58.2 \%)$ as the five most requested types of training by business and industry (Lynton, 1984). A more recent survey by the Bureau of Labor Statistics found computer, professional and technical, and management skills training to be the most common types of formal training offered to corporate workers (BLS, 1996, December 19). In 1997, companies spent nearly half of their training budgets on professional and technical skill training (Gehres III, 1998). 
Large variations exist between industries as to the type of training provided. For example, 80 percent of utility, finance, insurance, chemical and petroleum-product companies reported offering computer skills training compared to 30 percent of the retail sector (Lynch and Black, 1996). Incidences of computer and teamwork training increased with the rise in employee education level, while the proportion of minorities on staff lowered the incidence of computer training. Conversely, a higher proportion of female employees tended to increase the amount of formal training for sales and customer service training. A high percentage of technical workers increased the likelihood that a company offered teamwork training (Lynch and Black, 1996). Industry and employee characteristics appeared to predict the kind of formal training opportunities offered to employees.

The company size and age of workers also influenced the frequency of formal training. Companies of 500 or more employees provided 71 percent of employees with an average of 16.6 hours of formal training annually, compared with a 62 percent participation rate and 8 hours of formal training annually for companies with fewer than 100 employees. The youngest and oldest workers were less likely to get formal training and received the lowest total hours of formal training. Professional and technical workers received the highest number of both formal and informal training hours (BLS, 1996, December 19).

Recipients of training. College graduates, mostly white men, in professional, supervisory, and managerial positions at companies with 100 or more employees received most of the formal training (BLS, 1996, July 10). Ninety percent of workers with a bachelor's degree or higher received formal training in 1994, compared to only 60 
percent of employees with a high school education (BLS, 1996, December 19). These better-educated groups received, on average, 23 hours of formal training compared to four hours for the bottom quartile of learners (i.e., a high school education or less). Business leaders considered professional staff and the technical elite the best investments for high returns on training because of low turnover rates and the locus of control over their work environment (Carnevale and Johnston, 1989).

Training providers. Training providers can be in-house staff or outside vendors. Companies often use both types of providers. The right combination of providers, however, was dependent on type of training needed, number of employees, complexity of business, and resources. Corporate entities of 500 or more, for example, often used a combination of providers. Outside vendors were used to provide specialized training such as software training, while in-house trainers often perform orientation and standard office training programs. Organizations of 500 or less, generally rely more on outside vendors for training since the cost of in-house training staff was prohibitive.

In the $1994 \mathrm{EQW}$ study, respondents reported that they conducted 60 percent of their training in-house. Various types of outside vendors provided the remaining 40 percent. The following percentages indicate how often a vendor was mentioned, not the percentage of training provided. Outside vendors included equipment and suppliers $(50 \%)$, private consultants $(36 \%)$, private industry councils or associations $(34 \%)$, technical and vocational institutions (33\%), community and junior colleges $(30 \%)$, fouryear colleges and universities (20\%), other governmental agencies (12\%), and unions (5\%) (Lynch and Black, 1996). Businesses use outside vendors when the expertise is not available internally. Vendors can also eliminate duplication of services and facilities, be 
more cost effective, and produce comparable results to an in-house training program (Powers, et al., 1988).

The amount of money spent on in-house and outside training and the number of hours of training offered per employee varied widely among industries. Transportation, public utilities, and mining spent the most on in-house and outside training. The manufacturing, construction, and retail trade spent the least on outside training. Transportation and communications provided the most number of hours of formal training. Retail and construction establishments provided the fewest hours of formal training (BLS, 1996, July 10). Despite these variations in type and support for training, almost all firms reported investing in some kind of employee training and development.

The explosion of technology and the trimming of large company training staffs to focus more on core businesses have big companies seeking more help from outside vendors. Mid-sized and small companies need training services, but can not afford inhouse training staff. These factors make finding outside vendors, such as community colleges and four-year colleges and universities, vital to the success of a companies human capital development program (Carnevale, et al., 1990).

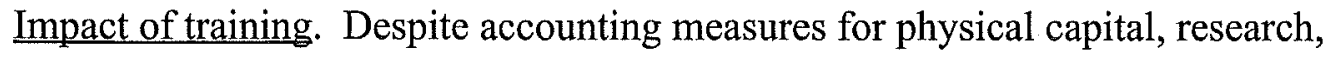
and development investments, companies have not defined a consistent and effective means to measure human capital investments (Bassi and McMurrer, 1998). The American Society for Training and Development (ASTD), however, has found some preliminary evidence to suggest that companies that invest more heavily in training are more productive and profitable. These data came from a 1997 Human Performance Practices Survey and ASTD's Benchmarking Forum (Bassi and Van Buren, 1998). The 
companies with the highest training expenditures per employee in 1996 experienced $\$ 386,171$ net sales per employee. The bottom half experienced only $\$ 245,091$ net sales per employee. The annualized gross profits of the top half were $\$ 168,486$, compared to $\$ 121,412$ for the lower half (Bassi and Van Buren, 1998). This limited data may provide some comfort to executives investing in training; yet, the absence of a reliable tool to measure training outcomes makes decisions about training and development difficult for business and industry leaders.

Future corporate training practices. Over the next decade, the categories of jobs predicted to have the fastest growth rates are managerial, professional, and technical occupations (BLS, 1997). These opportunities were likely to be found in small firms with fewer than 20 employees (Zemsky and Oedel, 1994). Paradoxically, these trends indicate an increase in occupations most likely to receive training combined with employers who are least likely to offer training. Medium and small firms will need to find ways to provide ongoing, continuous training to remain competitive. These size firms will likely seek outside vendors for training services, since an in-house training staff is financially impractical.

Most employer-sponsored training is non-sector specific and offered to welleducated employees on subject matters such as technology, management, and communications, which are taught routinely at colleges and universities. As the corporate sector makes an increasingly larger investment in staff training and development, colleges and universities are well positioned to provide these services to the corporate sector. 


\section{Corporate Commitment to Training Increases}

Technology advancements, international competition, changing attitudes toward work and careers, and shifting demographics portend a dramatic increase in the demand for training and development (Powers, et al., 1988). The impact of these changes include: an increased rate of skill obsolescence requiring more re-training; a trend toward more technologically sophisticated systems requiring more cognitive skills; a shift to service industries requiring more interpersonal skills; and an increased influence of international markets requiring more effective cross-cultural interaction (Goldstein and Gillian, 1990). For businesses to remain competitive, they will need to invest in their employees' skill development.

Recent studies provide support that company executives are increasingly committed to training and development. The $1994 \mathrm{EQW}$ study found that 57 percent of employers had increased their formal training since 1990, and 81 percent of respondents provided formal training (Lynch and Black, 1996). The Bureau of Labor Statistics (BLS) conducted a similar survey in 1995, asking 12,000 companies of varying sizes how much formal and informal training they offered. This study found 71 percent of establishments offered formal training programs, and 84 percent of employees reported receiving formal training (BLS, 1996, December 19). From 1992 to 1995, companies of all sizes reported training a greater percentage of their staff and had an overall increase in spending on training and development (BLS, 1996, July 10). In 1996, businesses spent 10 percent more per employee than in 1995 (Gehres III, 1998).

As technology continues to change many aspects of work, home, and community life, the need to improve the level of skill and adaptability of each worker accelerates. In 
the old economy, workers followed orders and completed assigned tasks. The new technology pushes the control of efficiency, quality, and innovation down the line toward the mass of employees at the point of production and service delivery (Carnevale, et al., 1990). Professional success now demands being able to identify and solve problems quickly. This type of performance can only come from a cycle of learning that requires the constant unlearning and relearning of technologies, adapting to new organizational forms, and generating new ideas (Powers, et al., 1988). Concurrently, employers no longer guarantee lifetime employment or an institutional pension. Retirement and healthcare choices, as well as career management and development are now a worker's responsibility. Further, the information economy requires workers to be flexible and ready to change jobs frequently (Chmura, 1986). The changing nature of work forecast a future where employees will constantly be seeking information and new learning opportunities.

Over the past two decades, changes to the work environment have dramatically redefined the landscape for American workers. Many industrial workers and middle managers have been displaced by corporate re-structuring and the changing skill demands of the new economy. From January 1995 through December 1997, 3.6 million workers were displaced from jobs they held for at least three years (U.S. Department of Labor, Bureau of Labor Statistics, 1998). An additional 4.4 million workers, who had less than three years of tenure at their current employer, were also displaced. The total of displaced workers during this period equaled 8 million. Conversely, hundreds of thousands of new jobs were created in the technology and service sectors. The Department of Commerce estimated that the United States will require 1.27 million 
information technologists by the year 2006 (U. S. Department of Commerce, Office of Technology, 1997). The trend toward corporate restructuring, the displacement of industrial and middle management workers, and the growing demand for technically skilled workers are likely to continue to affect the economy. The need to re-educate and train displaced workers and train new information technologist lends further support that the demand for training and development services will continue unabated.

Historically, higher education and the business community have worked together to find solutions to labor force training issues (Fairweather, 1988). If the American labor force is to adapt to the new economy, compete globally, and use technology effectively, higher education and the business community will again need to find appropriate and systematic ways to work together to meet the growing demand for education and training (Carnevale, et al., 1990; Cervero and Scanlan, 1985; Davis and Botkin, 1994; Fairweather, 1988; Kerr, 1994; Lynton, 1984). Otherwise, the negative effects on the American economy and the workforce will be far-reaching.

\section{Partnerships between Business and Higher Education}

American business/higher education partnerships find their antecedents in the nineteenth century with the passage of the Morrill Act of 1865 . This Act helped to stimulate cooperative arrangements between industry and higher education and transform an agrarian-based economy to an industrial-based economy (Fairweather, 1988). During this time, higher education also began preparing all social classes of Americans, not just the privileged, to meet the skill demands of an industrial-based economy (Veysey, 1965). Through the last century, higher education's relationship with the business sector has 
remained important, but has grown or diminished depending on the competing interests of federal and state government, education, and business leaders (Kerr, 1994).

Partnerships have taken a variety of forms including faculty exchanges, faculty consulting, collaborative research projects, executive education, customized non-degree workforce training programs, shared equipment and facilities, corporate internships, cooperative education and training, advisory relationships, philanthropic relationships, and articulation agreements (Eurich, 1989; Valentine, 1997). The research on business/higher education partnership has been categorized into three areas: research, economic development, and human resource development. This research study focused primarily on economic and human resource development.

Although limited empirical data exist to quantify the effectiveness of higher education/business workforce development partnerships, state and federal governments and a coalition of business and national association leaders believe that the continuing growth of these alliances will help create a more productive and effective workforce (Fairweather, 1988). A Coopers and Lybrand study of the top 424 fastest growing companies reported that those companies with a university relationship had 59 percent more revenue per employee than those without a partnership (Valentine, 1997). In a study examining the state of business/higher education partnerships, Gerlach (1992) found that despite feelings of distrust and skepticism among members of the corporate and educational communities, the number of successful alliances has increased significantly over the past thirty years. This growth was stimulated primarily by a concern with foreign competition and a decrease in domestic productivity. Both sectors reported finding the partnerships beneficial. 
The most common reason for establishing partnerships were a perceived compatibility of purpose and mission (Charner and Rolzinski, 1987). The closer selfinterests overlap, the easier partners were able to meet mutual needs and ignore differences. Congruently, pre-existing ties between business and higher education increased the likelihood of partnerships, as did the geographic proximity of the business and institution (Ball, 1994; Chmura, 1986; Valentine, 1997).

The corporate sector develops partnerships to serve a variety of purposes. A National Science Foundation study reported five reasons business develops partnerships with higher education: 1) to meet corporate product, service, or management needs; 2) to gain access to personnel in fields where talent is rare, such as certain computer science and engineering specialties; 3) to upgrade the development of corporate employees; 4) to minimize research costs; and 5) to take full advantage of federally sponsored research (Powers, et al., 1988, p. 23). Fairweather (1988) added that industry/university partnerships provided mechanisms to create new high technology industries, increase the rate of technological transfer, create new jobs, and develop new products. Businesses used partnerships to expand knowledge capacity, develop employees, and as a means to leverage their investment in human capital.

Higher education collaborates with business for several other reasons including: 1) providing a revenue stream to the institution; 2) increasing student exposure to realworld research problems; 3) developing better training programs for the increasing number of graduates going into industry; 4) avoiding some of the "red tape" and timeconsuming reporting requirements that obtaining government money involves; 5) working on challenging research projects of immediate importance to society; and 6) 
gaining access to company research facilities and equipment (Powers, et al., 1988, p. 25). Partnerships with business have also allowed higher education to develop innovative curriculum, expand community networks between the academic and business community, and meet the training demands of private business (Fenwick, Giorgio, Kopecky, Lloyd, and Myers, 1986). Partnerships offer higher education an opportunity for faculty and students to test theory in practice and a process to build closer, more positive relationships with the business community.

The benefits of partnering appear to be spurring the growth in business/higher education partnerships. One study reported that these partnerships grew five-fold from 1975-1985 (Fairweather, 1988). Davis and Botkin (1994) estimated that 140,000 business/education partnerships now exist. Ninety percent of community colleges reported being involved in partnerships with business and industry (Eurich, 1989). A 1986 survey of 300 four-year postsecondary institutions indicated that 97 percent planned to initiate activities related to economic development (Chmura, 1986). Although the information about the type and scope of higher education/business partnerships is unclear, these partnerships appear to include all types of businesses and higher education institutions.

The paucity of research studies regarding the growth of business/university corporate training partnerships, however, limits the understanding of how actively involved universities are in these types of partnerships. As economic influences of technology, globalization and shifting demographics increase the demand for training, the need to understand the effectiveness of business/higher education training partnerships grows proportionately (Burton, 1992; Norris, 1998; Peterson and Dill, 1997). 


\section{Research Studies on Business/Higher Education Training Partnerships}

Since very little research has been conducted on business/university corporate training partnerships, community college/business contract training partnerships offer the closest link to this project and provide a breadth of valuable information. In this section, community college/business contract training partnerships are discussed in terms of their purpose and value, as well as the benefits they have to the provider, client, and worker.

Contract training is "an arrangement in which an organization, whether a business, a government agency, or volunteer association, contracts directly with a college for instruction of its employees, its clients, or its members" (Alsanian, 1988, p. 243). The instruction is provided for specific occupational purposes usually outside the college credit program and falls into three categories: training designed specifically for the employees of certain companies; training for public agency employees; and training for specific groups such as unemployed people or people on welfare (Cohen and Brawer, 1989). The specific focus of this study is on the training of corporate employees.

Contract training for business can include general topics such as management and communication courses as well as industry specific courses such as advanced electronics for engineers.

Contract arrangements between business, government agencies, and voluntary associations and colleges were as varied as the entities themselves. The Office of Adult Learning Services of the College Board conducted a nationwide survey of contract training in 1982 and found a number of patterns and characteristics regarding these partnerships including: 1) each type of college has been involved in contract training- 
from Harvard University to Piedmont Technical College in South Carolina: 2) each type of organization has the capacity to learn and has been involved in contract training from Monsanto Textiles Company to the Catholic Diocese of Corpus Christi: 3) a broad range of subject matter from peptic ulcer therapy to financial management, computer training for managers, and conversational French has been taught in contract training programs: and 4) organizations usually have paid for the employee training (Aslanian, 1988). Contract training allowed organizations to address specific training needs with a provider that has the appropriate expertise. The flexibility of the delivery method, the specificity of the training, and not having to hire full-time training staff make contract training a viable and important workforce development option for many organizations.

Contract training was used in the corporate environment to accommodate the growth and turnover in personnel, to meet industry changes in knowledge and skills, and to improve current job performance (Aslanian, 1988). A growing technology firm, for example, might engage a training vendor to provide new personnel with software instruction. The same firm, due to the speed of technological change, might also elect to engage a training provider to upgrade the technical skills of existing employees. Lastly, a training provider might be hired to conduct a management and supervision training course to build a more effective management team. Contract training allows organizations to address current workforce development needs with the right training, at the right time, and in the right environment (Meister, 1994).

Previous research studies of university/business workforce partnerships provided only a limited view of university involvement in corporate training. A $1987 \mathrm{New}$ England Higher Education Association study of human resource managers reported using 
public four-year colleges and universities to provide a range of training programs. The percentages that follow represent the ratio of human resource managers that used colleges and universities for these types of training programs. The programs most frequently provided by colleges and universities included management (55.3\%), professional specialist (53.3\%), sales and customer service (32.2\%), and technical skill development (31.4\%) (New England Board of Higher Education, 1987). The Bureau of Labor Statistics reported that larger companies used community colleges and other educational institutions in more than half of their training cases (BLS, 1996, July 10).

Many community colleges have recognized corporate contract training as a viable revenue-producing activity as well as an opportunity to build partnerships with their local business community. One study found that 75 percent of all community colleges provided some customized contract training and assign staff to develop these programs (Carnevale, et al., 1990). Ball (1994) found that community college contract training grew from an enrollment of 5,000 in 1980 , to 68,000 in 1989 . The dollar volume rose from $\$ 200,000$ in 1980 , to $\$ 13$ million in 1988 . The dramatic growth was linked to the outreach efforts by the community college and the cooperative efforts between the college and business to design the programs.

The Iowa Continuing Education Board asserted that business leaders used community colleges to meet their corporate training needs for several reasons: career/job preparation and lifelong learning as a fundamental mission; extensive and effective links with local business, industry, labor, and government constituents; high-quality training at a reasonable cost; and an emphasis on customer-focused, workforce training partnerships with local business/industry constituents (Iowa State Department of Education, 1996). 
The high percentage of community colleges involved in corporate training suggests that they were meeting corporate expectations of producing a quality product at a reasonable cost and with attention to customer service.

Ballantyne (1985) identified seven commonly accepted principles for effective delivery of community college workforce development programs to business and industry. These included: 1) internal commitment from all of the college's resources including personnel, curriculum, equipment, facilities, and information; 2) defining process, systems and procedures; 3) training; 4) building resources such as personnel, curriculum, equipment, and facilities; 5) marketing process; 6) delivery; and 7) evaluation (Anderson, 1995). The college president's leadership style also played an important role in the success of business/higher education partnerships. In a case study of three community colleges in California, Lusk (1987) stated: "It was very clear that the two successful colleges had presidents who were strong leaders possessed a strong sense of mission and were clear that reaching out to business and industry was a high priority" (p. 138). This study also strongly encouraged administrators and college boards to commit to "taking a proactive, rather than reactive approach to joint ventures with the private sector"(Lusk, 1987, p. 139). Another important effectiveness factor is a commitment by the institution to pursue these opportunities (Aslanian, 1988). This included market research, curriculum adjustments, modified time scheduling, and teaching that connects the learning to job-related improvements. Effective providers invested money and human capital to build positive business relationships.

Contract training partnerships with industry have provided many benefits to community colleges. The arrangements have expanded the colleges' service mission and 
regional economic revitalization efforts (Powers, et al., 1988). Internally, they have provided professional development to staff, increased the use of college facilities, and expanded academic access to the community. Partnerships have also provided job placement opportunities, increased the colleges' visibility in the greater community, and given the colleges positive public relations. Wakefield (1992) found that community colleges also profited from these alliances by increased credibility with the business sector and increased donations. Moreover, community colleges have benefited through increased opportunities for teachers to put theories into practice, internships for students, and faculty research and development projects (Aslanian, 1988). Lastly, workforce partnerships spawned other types of relationships, including shared facilities and staff, apprenticeships, and opportunities for student work-study programs.

Contract training programs provide many advantages to the participant compared with a typical credit-based course at a college or university. The student benefits included: convenient times and places to study, a clearer understanding of the connection between theory and application, greater contact with other students with similar career objectives, more chances to practice classroom skills on the job, less concern about jobs after graduation, greater ease in updating skills throughout their careers, and greater access to instructors who are current in their fields (Alsanian, 1988). These mutual advantages to both the employer and employee make contract training an attractive and effective format to meeting the corporate sector's demand for training and development.

Despite the benefits, there were obstacles to developing business/higher education partnerships. Some of the obstacles included: a) differences in the attitudes of those involved; b) differences in administrative philosophies and; c) contrasting professional 
work styles (Aslanian, 1988). Partnerships have struggled with how to mix the shortterm, profit-oriented business goals with the theoretical, individual achievement goals of higher education. At doctoral-granting institutions, for example, faculty received little incentive to participate in service programs such as corporate training that did not directly advance research or the teaching mission of the university (Fairweather, 1988). The limited flexibility of the current academic organizational structure and the faculty reward system frustrates business and industry leaders (Powers, et al., 1988; Shoemaker, 1998).

Another challenge for building business/higher education partnerships was convincing some in higher education that these partnerships did not endanger the university as an independent enterprise and lead to the crippling of the tradition of an independent university (Fairweather, 1988; Green, 1997). Whether through defining the research agenda or modifying the mission to include economic and workforce development, each dimension had the ability to change the character of an institution. Those in higher education who oppose business/higher education partnerships wondered whether these liaisons change academic institutions in ways that increased social and economic benefits to society or "whether academic/industrial partnerships will be another in a long line of educational fads, leaving little imprint on the social fabric"(Fairweather, 1988, p. iii).

Businesses and community colleges reported some program quality issues. Problems have included unqualified instructors, inadequate facilities (i.e., technology training), difficulty scheduling courses around work shifts, faculty reluctance to participate, short-term period for course development, and lack of suitable marketing strategies (Powers, et al., 1988). Businesses also required training providers to focus on 
professional competencies, individual educational needs, learning modules, off-campus delivery, and a willingness to use distance-learning modes of transmission rather than focusing on traditional courses, degrees, or programs (Peterson and Dill, 1997). Due to conflicting internal and external institutional priorities, higher education was not always prepared or positioned to meet all of these demands.

Although problems existed, the actions of business and higher education leaders indicated that partnerships were beneficial to corporations, the workforce, and higher education (Gerlach, 1992). As these relationships continue to grow in size and scope, the need to understand the implications of these relationships become increasingly important for both higher education and the business sector. A study to explore business/higher education training partnerships provides both communities with a better understanding of each other's role in developing effective partnerships.

\section{Conclusion}

The economic forces of technology, globalization, and shifting demographics make information and knowledge the currency of the new information economy. Companies that develop the most educated and knowledgeable workforce have the competitive advantage in the global marketplace. Human capital development, therefore, has grown increasingly important to individual and corporate success. The current shortage of technology workers and "knowledge workers" exemplifies how economic changes can affect the labor market. The business sector, federal and state government leaders were collaborating to address workforce training issues. The higher education community was being sought to play a prominent role. 
Historically, higher education has played an important role in the development of the labor force and has participated within the traditional missions of teaching, research, and service. Higher education again appears well positioned to support the business sector's increasing need for training and development services. The type of learning experiences most demanded by the corporate sector, such as technology, management, and communication, were courses commonly offered as part of the university curriculum. Universities possess knowledge, information, and the necessary organizational infrastructure, through a division of continuing education, to offer corporate training programs to business and industry. In addition, community colleges have demonstrated that workforce development partnerships were productive and beneficial to both business and higher education.

Yet, the current perception in the literature and the limited research on the topic suggested that colleges and universities have been generally unresponsive to addressing the training needs of the business community. This study gathered information to understand better how colleges and universities were responding to the growing demand for training and development. 


\section{CHAPTER THREE}

\section{METHODOLOGY}

\section{Introduction}

Standard survey research techniques were employed to identify the important issues regarding higher education's role in training and development for business and industry. The study examined training and development issues from a "contract only" basis. This approach allowed for a more concise and refined approach to researching a phenomenon such as training that otherwise would be difficult to measure. For example, capturing the incidences of training would require a survey of each employee, since any course sanctioned or not by the company could be considered a training opportunity. Having a singular research focus on contract training provided respondents and the researcher with a definition of training and development that was both understandable and measurable.

\section{Research Questions}

The purpose of this descriptive study was to improve the understanding of what kind, to whom, and how often universities were providing corporate training services, and learn more about the benefits and barriers of offering these programs to business and industry. Seventeen research questions were developed based on this purpose statement, from findings in the literature, counsel from four University of Virginia faculty members, and interviews with continuing education professionals. 
1. Are corporate workforce development activities an accepted part of the continuing education units' mission?

2. What financial support does the university provide for corporate training programs (i.e., are corporate workforce development programs expected to be self-sufficient)?

3. How many staff members are dedicated to corporate contract training activities?

4. How many corporate contract training programs are offered each year by continuing education units?

5. Are continuing education units' corporate training programs serving local, regional, national, and international interests?

6. What was the 1998 enrollment in continuing education sponsored corporate contract training?

7. How much revenue do corporate training programs produce?

8. Are continuing education units increasing or decreasing their involvement in contract training?

9. Are continuing education units satisfied with their corporate contract training programs?

10. What types of corporate training programs do continuing education units offer?

11. What type of training does business and industry most commonly request?

12. What level of employee do continuing education units' contract training programs most often serve?

13. What size companies are seeking corporate contract training services?

14. What types of businesses are seeking contract training services from continuing education units?

15. What university benefits are derived from offering contract training programs to business and industry?

16. What problems and barriers limit universities from providing corporate contract training programs?

17. What characteristics facilitate effective corporate contract training programs between business and higher education? 


\section{Population and Sample}

From the population of 236 Carnegie classified doctoral-granting universities, 195 institutions were selected as the study sample. Doctoral-granting universities were purposefully chosen as the sample set, because the largest institutions in the country based on enrollment, and those most likely to have the infrastructure and financial means to support outreach programs such as continuing education, were contained in this subset of higher education (Shoemaker, 1998). Doctoral-granting institutions maintain continuing education departments at a higher rate $(90 \%+)$ than the national average of 72 percent. In addition, universities have built more collaborative relationships with the business community through faculty consulting, corporate recruiting, and research projects than other types of four-year institutions (Powers, et al., 1988). Finally, public universities have a mission to serve local, regional, and states interest through outreach efforts, and were more likely to support continuing education.

All 236 doctoral-granting institutions were researched to ascertain whether they supported an university-wide continuing education unit and had a dean or director of continuing education. The American Council on Education (ACE) provided a database of Carnegie classified doctoral-granting universities, with the main address and telephone number for each institution. The 1999 Higher Education Directory (Rodenhouse and Torregrosa, 1998), the University Continuing Education Membership Directory 1996-97 (1996), and phone contact were used to find the director or dean of continuing education. The database for the survey mailing was created from this research. This resulted in the identification of 195 institutions that supported an university-wide continuing education 
unit and had a director or dean of continuing education (see Appendix E for participating and non-participating institutions). All 195 were included in the study.

\section{Instrument Development}

The survey was modeled after several other research studies on training and development. Wolin-Deluca (1991), Ball (1994), and the Department of Commerce, Bureau of Labor Statistics (1996, July 10) studies were especially helpful in the design and creation of the instrument. Based on these and other corporate training higher education/business partnership research, and the seventeen research questions, a 31-item survey was constructed (see Appendix A). The survey contained only closed-answered, rated, and categorical scale questions. Most questions allowed respondents to offer additional information by checking "other" and then inserting a response.

The survey was divided into four sections: University Corporate Contract Training Programs (12 questions); Corporate Training Characteristics (8 questions); Benefits and Barriers to University Provided Corporate Contract Training (3 questions); and Organizational Information and Institutional Demographics (8 questions). Appendix B contains The Table of Specifications that illustrated how each research question was addressed in the survey.

\section{Pilot Study}

In the fall of 1998, the rèsearcher attended the Region III University Continuing Education Conference to discuss this research project with practitioners. At the conference, contact was made with Phillip Robinson, the director of government relations at UCEA, and the chair of Region III, Dr. Theodore Settle, director of continuing education at Virginia Polytechnic Institute, and State University. Through these contacts, 
seven professionals interested in corporate training and development were identified to participate in this research project's pilot study. This group of seven were asked by phone to pilot the questionnaire for face and content validity. An explanation of the research project and its purpose were part of these discussions. Five individuals accepted the offer to participate including: William Clutter, director of continuing education at Pace University; Denis Parks, associate dean of continuing education at the University of Virginia; Theodore Settle, director of continuing education at Virginia Polytechnic Institute and State University; Wendell Smith, vice president external relations at the University of St. Louis; and Patrick Valentine, director of corporate training. A follow up email included the draft survey and an evaluation form for each participant to complete (see Appendix F and G).

After each participant had completed the survey, a follow up phone conversation was arranged to elicit feedback. The focus of these discussions centered around the following issues: were there any missing questions; who should be asked to complete the survey; how long did the survey take to complete; what recommendations do you have about style, tone and language; what recommendations do you have about organization of the questions; which questions were difficult to complete; and do you think the survey will assess university continuing education's role in providing training and development to business and industry.

The participants were instrumental in guiding the researcher in improving the clarity, length, and organization of the survey. Four of the five pilot participants suggested that "workforce development" programming should be changed to "corporate contract training" programs throughout the survey. The term "workforce development" 
had different connotations to continuing education professionals than what was intended by this research project. Three of the five remarked that the 44-question survey seemed to long and needed to be organized more topically to keep the participants interested. The result of these suggestions was to reduce the survey from 44 questions to 31 , and create four sections. Both measures helped improve readability and clarity.

Two participants encouraged a change in the scale of the responses to some questions. For example, the question related to the number of corporate contracts supported by continuing education provided 1-49 contracts as the first response choice. Their suggestion reshaped this response choice to 1-10 contracts. A couple of pilot participants remarked that the survey was missing questions that measured expectations of future growth and current satisfaction ratings. Questions addressing these two areas were incorporated into the survey.

The expert feedback helped the researcher understand and address concerns regarding how well the survey matched the intent of the study; whether the constructs and language were appropriate to the respondents; how long it took to complete; and if the data collected would provide useful information about the research questions. These procedures resulted in a research instrument with a high level of face and content validity.

\section{Administration of the Instrument}

On November 1, 1999, a personalized cover letter (see Appendix C), a copy of the Corporate Contract Training Survey, and a return self-addressed, stamped envelope were mailed to 195 institutions. The letter was addressed to the director or dean of continuing 
education. The letter described the value of the research and the importance of participation by each respondent. To encourage greater participation, the researcher obtained an endorsement from the incoming president of UCEA, Dr. Wendell Smith; the co-commissioner of research for UCEA and assistant dean of continuing education at Louisiana State University, Doreen Maxcy; and the chair of UCEA's commission on Futures and Markets, Theodore Settle. This endorsement was in the postscript at the bottom of the cover letter. The cover letter was printed on the Center for the Study of Higher Education, Curry School of Education, University of Virginia letterhead.

The identity of the participating institutions and respondents were kept confidential by using an identifier code on each survey. The survey code allowed the researcher to conduct all necessary follow up with non-respondents. Participants who did not return the first questionnaire by November 28, 1999, received a second letter and survey on December 1,1999 (see Appendix D).

The two mailings produced 117 responses from a population of 195 . The first mailing produced 72 responses, and the second mailing returned 45 additional responses. Six of the 117 returned surveys were invalid, because two responses came from specific university departments (i.e., computer science and business) and four other responses arrived after the data had been analyzed. The total number of responses analyzed as part of this research was 111 . The overall response rate was 60 percent. The total useable survey response rate was 56.4 percent. Both response rates exceeded the anticipated 50 percent return rate. 


\section{Data Processing and Analysis}

This study included the identification of certain characteristics and attributes of university corporate workforce training and development programs. A Microsoft Excel database was constructed to manage and process the responses. Percentages were calculated in order to determine the relative priority of issues, the ranking of company sectors, training programs offered and received, benefits and barriers, and level of involvement by continuing education units in training and development.

A frequency distribution for each question was compiled and an aggregate profile of doctoral-granting institutions' responses was then produced. This aggregate profile was used as a baseline of data to compare various sub-samples based on institutional size, type, Carnegie classification, and location. Comparisons were conducted on questions related to institutional support, number of corporate contracts, types of programs provided, level of employee receiving training, business sectors seeking services, whether services were increasing or decreasing, benefits, and barriers. The comparisons helped the researcher identify the size and type of institutions most and least involved in contract training, whether Carnegie classification affected institutional involvement, the location where the most and least training occurred, and the significant issues regarding continuing education's participation in corporate training and development.

\section{Study Limitations}

Study limitations resulted from the methodological approach, the sample, and the organization of continuing education divisions. Surveys rely on self-reported data. The researcher could not control who completed the survey or the reliability of information 
collected from individual sources. The population of universities used for this study was affected by current and former state economic policies (Stevens, 1992). These policies determine how committed states were to economic development, how dollars were allocated, and how tuition policies were decided. These factors directly affected a university's ability to support economic and workforce development-related activities. Lastly, continuing education units were organized in a variety of ways that included academically centralized and administratively centralized, academically centralized and administratively decentralized, academically decentralized and administratively centralized, and academically decentralized and administratively decentralized. Less centralized continuing education programs may have found completing the survey more difficult to complete. 


\section{CHAPTER 4}

\section{PRESENTATION AND ANALYSIS OF DATA}

\section{Introduction}

This chapter will summarize and analyze the data collected for the study in narrative and tabular formats. The chapter is organized into three sections: a) a demographic profile of respondents; b) the research questions; c) profile comparisons of groups based on type (public institutions compared to private institutions), enrollment size (institutions with enrollments of 10,000-19,999 compared to institutions with enrollments of 20,000 or more), Carnegie classification (research institutions compared to doctoral institutions), and location (urban institutions compared to small city institutions). A summary of the significant findings is presented at the end of each section. The chapter concludes with a summary of the overall important findings.

Some respondents did not respond to every question in the survey, therefore the number of respondents $(\mathrm{N}=)$ is different in a few tables. If a table has significantly fewer respondents than the total population, an explanation will follow the table.

\section{Demographic Profile}

The first table presents the institutional demographics of the respondents in two parts according to type, enrollment, location, UCEA region, and Carnegie classification, and continuing education units' organizational structure. Table 1 shows the number of responses for each category and a percentage based on the total number of responses. 
Table 1

An Analysis of the Survey Participants Based on Demographics

\begin{tabular}{|c|c|c|}
\hline Institutional Demographics & $\begin{array}{l}\text { Total Responses } \\
(\mathrm{N}=111)\end{array}$ & $\begin{array}{l}\text { Percentage } \\
\text { of Total }\end{array}$ \\
\hline $\begin{array}{l}\text { Type of Institution } \\
\text { Public } \\
\text { Private } \\
\text { Other }\end{array}$ & $\begin{array}{c}73 \\
38 \\
1\end{array}$ & $\begin{array}{c}66 \% \\
34 \% \\
0 \%\end{array}$ \\
\hline $\begin{array}{l}\text { Enrollment of Institutions } \\
2,500-4,999 \\
5,000-9,999 \\
10,000-19,999 \\
20,000 \text { or more }\end{array}$ & $\begin{array}{c}6 \\
19 \\
47 \\
39\end{array}$ & $\begin{array}{c}5 \% \\
17 \% \\
42 \% \\
35 \%\end{array}$ \\
\hline $\begin{array}{l}\text { Location of Institution } \\
\text { Urban } \\
\text { Small City (population of } 100,000 \text { or less) } \\
\text { Suburban } \\
\text { Rural }\end{array}$ & $\begin{array}{c}66 \\
34 \\
7 \\
4\end{array}$ & $\begin{array}{c}59 \% \\
31 \% \\
6 \% \\
4 \%\end{array}$ \\
\hline $\begin{array}{l}\text { Top } 5 \text { States } \\
\text { Texas } \\
\text { Massachusetts } \\
\text { New York } \\
\text { Ohio } \\
\text { California }\end{array}$ & $\begin{array}{l}11 \\
8 \\
8 \\
8 \\
8\end{array}$ & $\begin{array}{r}10 \% \\
7 \% \\
7 \% \\
7 \% \\
7 \%\end{array}$ \\
\hline $\begin{array}{l}\text { Responses by UCEA Regions } \\
\text { Region I (CT, MA, ME, NH, RI, VT) } \\
\text { Region II (DC, DE, MD, NJ, NY, PA, WV) } \\
\text { Region III (AK, AL, FL, GA, KY, LA, MS, NC, } \\
\text { SC, TN, TX, VA) } \\
\text { Region IV (IL, IN, MI, MN, MO, OH, WI) } \\
\text { Region V (CO, KS, ND, NE, OK, SD, WY) } \\
\text { Region VI (AZ, CA, NV, UT) } \\
\text { Region VII (AK, HI, ID, MT, OR, WA) }\end{array}$ & $\begin{array}{c}13 \\
19 \\
33 \\
\\
20 \\
7 \\
12 \\
6\end{array}$ & $\begin{array}{c}12 \% \\
17 \% \\
30 \% \\
\\
18 \% \\
6 \% \\
11 \% \\
5 \%\end{array}$ \\
\hline
\end{tabular}


Table 1 (continued)

Carnegie Classification
Research I
Research II
Doctoral I
Doctoral II

Carnegie Classification

Research I

Research

Doctoral II

\begin{tabular}{l|l} 
& \\
44 & $40 \%$ \\
32 & $29 \%$ \\
15 & $14 \%$ \\
20 & $18 \%$ \\
\hline
\end{tabular}

Table 1 shows the institutional demographics of the institutions that responded to the survey. The responses were comprised of 66 percent public institutions and 34 percent private institutions. This result closely matches the distribution of public and private doctoral-granting universities across the country, which are 64 percent public and 36 percent private (Rodenhouse and Torregrosa, 1998).

Institutions that enroll 10,000-19,999 students attracted the most responses (42\%). Institutions with enrollments of 20,000 or more had 39 responses (35\%). Institutions with enrollments of 9,999 and fewer drew 25 responses (22\%).

Urban area institutions represented the most responses (59\%). Small city institutions followed (31\%), and then suburban (6\%) and rural (4\%).

The survey drew responses from forty-two states. Five states had eight or more institutions responses. Texas produced the most responses (11), followed by Massachusetts (8), New York (8), Ohio (8), and California (8). These states also rank in the top 10 states with the most colleges and universities (Rodenhouse and Torregrosa, 1998).

University Continuing Education Association (UCEA) Region III, Southeastern and Central states and UCEA's largest region, represented 33 responses (30\%). Region IV, Midwest, had 20 responses (18\%). Region II, the Mid-Atlantic, represented 19 
responses (17\%). Region I, New England, drew 13 responses (12\%), followed by Region VI, Southwest and California, with 12 surveys (11\%). Region V, the Plain states, recorded seven responses (6\%) and Region VII, the Northwest and Hawaii, represented six responses $(5 \%)$.

Based on Carnegie classification, Research I, the largest sample in the population $(\mathrm{N}=77)$, recorded the highest number of responses with 44 (40\%). Research II, the smallest sample in the population $(\mathrm{N}=37)$, recorded 32 responses $(29 \%)$. The second largest sample $(\mathrm{N}=60)$, Doctoral II, completed 20 responses $(18 \%)$, followed by Doctoral I $(\mathrm{N}=51)$ with 15 responses $(14 \%)$.

Table 2

Continuing Education Organizational Characteristics

\begin{tabular}{|l|l|l|}
\hline Continuing Education Organization & Total Responses & $\begin{array}{l}\text { Percentage } \\
\text { of Total }\end{array}$ \\
\hline $\begin{array}{l}\text { CE operation is organized: } \\
\text { Academically centralized and } \\
\text { administratively centralized }\end{array}$ & 25 & $25 \%$ \\
$\begin{array}{l}\text { Academically decentralized } \\
\text { and administratively centralized }\end{array}$ & 46 & $46 \%$ \\
$\begin{array}{l}\text { Academically centralized } \\
\text { and administratively decentralized }\end{array}$ & 5 & $5 \%$ \\
$\begin{array}{l}\text { Academically decentralized } \\
\text { and administratively decentralized }\end{array}$ & 24 & $24 \%$ \\
\hline
\end{tabular}


Table 2 (continued)

\begin{tabular}{|l|c|c|}
\hline Title of continuing education CEO is: & $(\mathrm{N}=111)$ & \\
Associate Vice Chancellor & 1 & $0 \%$ \\
Dean & 63 & $57 \%$ \\
Vice Provost & 10 & $9 \%$ \\
Director & 24 & $22 \%$ \\
Associate VP & 5 & $5 \%$ \\
Other & 8 & $7 \%$ \\
\hline CEO reports to: & $(\mathrm{N}=102)$ & \\
President & 2 & $2 \%$ \\
Provost & 56 & $55 \%$ \\
Academic Vice President & 21 & $21 \%$ \\
Vice Provost & 12 & $12 \%$ \\
Other & 11 & $11 \%$ \\
& & \\
\hline
\end{tabular}

Table 2 provides the organizational structure of the continuing education units that responded to the survey. The most prevalent organizational structure for responding institutions was academically decentralized and administratively centralized (46\%). Administrative functions, such as human resources, budgeting, and information technology, are managed centrally in this structure. Academic programs are decentralized, which allow academic deans to make program decisions. This structure is typical of large, public institutions that are involved in research. This type of organizational structure allows continuing education units to have wide latitude over program development. A quarter of respondents reported having an academically centralized and administratively centralized organizational structure, followed closely by academically decentralized and administratively decentralized organizational structure (24\%). Academically centralized and administratively centralized structures increase the universities purview over continuing education programming, while the academically and 
administratively decentralized structures would provide continuing education units more autonomy in making programming decisions.

A majority of continuing education leaders was given the title of Dean (55\%).

Another 22 percent held the title of Director. Most leaders reported to the Provost (57\%) or the Academic Vice President (21\%) of their universities.

\section{The Research Questions}

The following section will address the seventeen research questions. Each research question is examined using the Operational Table as a guide (Appendix B). The analysis of the frequency distributions and percentages are provided in narrative and tabular formats. The table provides the number and percentage of the responses. The section concludes with a summary of the significant findings.

Research Question 1: Are corporate workforce development activities an accepted part of the continuing education units' mission?

The percentage of continuing education units that support contract training and why they are involved in contract training is shown in Table 3.

Table 3

The Extent to which Corporate Training is Part of the Continuing Education Units' Mission

\begin{tabular}{|l|l|l|}
\hline $\begin{array}{l}\text { Continuing Education Units with Corporate Training } \\
\text { Programs }\end{array}$ & $\begin{array}{l}\text { Respondents } \\
\text { (N=111) }\end{array}$ & $\begin{array}{l}\text { Percentage } \\
\text { of Total }\end{array}$ \\
\hline YES & 83 & $75 \%$ \\
\hline NO & 28 & $25 \%$ \\
\hline
\end{tabular}


Table 3 (continued)

\begin{tabular}{|l|l|l|}
\hline Why is your CE unit involved in Corporate Training? & $(\mathbf{N}=\mathbf{8 3})$ & \\
\hline a component of the CE mission & 71 & $85 \%$ \\
\hline produces needed revenue & 61 & $73 \%$ \\
\hline a demand from business community & 58 & $70 \%$ \\
\hline part of your institution's service mission & 52 & $63 \%$ \\
\hline pressure from institutional leaders & 4 & $5 \%$ \\
\hline other & 4 & $5 \%$ \\
\hline
\end{tabular}

Seventy-five percent of university continuing education units reported having some kind of contract training program with business and industry. Continuing education units were involved in contract training primarily for institutional and external environmental reasons. Continuing education units provided corporate contract training because most respondents considered this type of programming part of their mission (85\%). External environmental factors were important motivations too, as a greater percentage of respondents chose "produces needed revenue" (73\%) and "demand from the business community" (70\%) over contract training is "part of your institution's service mission" (63\%). The four "other" responses included marketing opportunities; good learning experience; university mission to serve graduates; and need for employees to update their skills.

Research Question 2: What financial support does the university provide for corporate training programs (i.e., are corporate workforce development programs expected to be self-sufficient)?

The extent to which respondents found their institutions supportive of their involvement in contract training is reported in Table 4. 
Table 4

The Extent to which Universities Provide Financial Support to Continuing Education Units for Contract Training

\begin{tabular}{|c|c|c|}
\hline $\begin{array}{l}\text { How are Corporate Contract Training } \\
\text { Programs Funded? }\end{array}$ & $\begin{array}{l}\text { Respondents } \\
\left({ }^{*} \mathrm{~N}=89\right)\end{array}$ & Percentage of Total \\
\hline revenue from corporate contracts only & 52 & $63 \%$ \\
\hline $\begin{array}{l}\text { a combination of university and training } \\
\text { contract resources }\end{array}$ & 17 & $20 \%$ \\
\hline revenue from other programs & 7 & $8 \%$ \\
\hline university budget & 5 & $6 \%$ \\
\hline other & 8 & $10 \%$ \\
\hline $\begin{array}{l}\text { What Ways do Universities support for } \\
\text { Corporate Training Programs? }\end{array}$ & $(* N=88)$ & \\
\hline some combination of the above & 33 & $39 \%$ \\
\hline provides physical/capital resources & 30 & $38 \%$ \\
\hline $\begin{array}{l}\text { has policies that encourage faculty to } \\
\text { participate }\end{array}$ & 7 & $8 \%$ \\
\hline $\begin{array}{l}\text { provides financial resources for } \\
\text { operations }\end{array}$ & 6 & $7 \%$ \\
\hline $\begin{array}{l}\text { senior officers participate in initiating and } \\
\text { negotiating contracts }\end{array}$ & 2 & $2 \%$ \\
\hline other & 17 & $20 \%$ \\
\hline
\end{tabular}

Continuing education units' corporate training programs were funded primarily through revenue produced from contracts (63\%). Twenty percent of the respondents used a combination of university budget and contract training revenue to fund their corporate contract training programs. The eight "other" responses offered more tangible ways their university supported contract training programs. The responses included office space, heating, air conditioning, janitorial services, library access, and university counsel to review contracts.

Universities were likely to support corporate contract training programs by providing physical and capital resources (38\%) or a combination of space, equipment, and institutional services, such as janitorial, utilities, and financial administration services 
(39\%). The "other" category received 20 percent of the responses. Most of these responses (10 of 17) reported that the university played little or no role in supporting their contract training programs.

Research Question 3: How many staff members are dedicated to corporate contract training activities?

The data in Table 5 presents the number of full time equivalent staff members continuing education units dedicated to their contract training programs.

Table 5

The Extent to which Continuing Education Units Staff Their Contract Training Programs

\begin{tabular}{|l|l|l|}
\hline Categories & $\begin{array}{l}\text { Respondents } \\
(\mathbf{N}=\mathbf{8 3})\end{array}$ & Percentage of Total \\
\hline 0-1 full time equivalent (FTE) & 39 & $46 \%$ \\
\hline 2-3 FTE & 26 & $31 \%$ \\
\hline 4-5 FTE & 9 & $11 \%$ \\
\hline 6-7 FTE & 3 & $4 \%$ \\
\hline 8 or more FTE & 6 & $7 \%$ \\
\hline
\end{tabular}

Most continuing education units (77\%) employed less than four full time staff members to manage their contract training programs. Twenty-two percent of institutions supported their contract training programs with four or more full time staff members. 
Research Question 4: How many corporate contract training programs are offered each year by continuing education units?

Table 6 shows the number of contracts managed by continuing education units.

Table 6

The Number of Corporate Training Programs Contracts Managed Each Year by Continuing Education Units

\begin{tabular}{|l|l|l|}
\hline Categories & Respondents $(\mathbf{N}=\mathbf{8 3})$ & Percentage of Total \\
\hline $1-10$ & 33 & $40 \%$ \\
\hline $11-25$ & 19 & $23 \%$ \\
\hline $26-50$ & 11 & $13 \%$ \\
\hline $51-100$ & 12 & $14 \%$ \\
\hline $101+$ & 7 & $8 \%$ \\
\hline not known & 1 & $1 \%$ \\
\hline
\end{tabular}

The $1-10$ contracts category received the largest number of responses (40\%). Yet, sixty percent of respondents managed 11 or more contracts annually. Twenty-two percent supported 51 or more contracts per year.

Research Question 5: Are continuing education units' corporate contract training programs serving local, regional, national, and international interests?

Based on the data in Table 7, most continuing education units served a regional business community.

Table 7

The Geographic Location of Continuing Education Units' Corporate Training Programs

\begin{tabular}{|l|l|l|}
\hline Categories & Respondents $(\mathbf{N}=\mathbf{8 4})$ & Percentage of Total \\
\hline $0-49$ miles & 53 & $63 \%$ \\
\hline $50-99$ miles & 14 & $17 \%$ \\
\hline $100-249$ miles & 9 & $11 \%$ \\
\hline 250 or more miles & 8 & $10 \%$ \\
\hline
\end{tabular}

Eighty-one percent served businesses within a 100-mile radius of their campuses.

Twenty-one percent extended their programs beyond this range and 8 percent served businesses that are 250 or more miles from their campus. It was not clear from the 
survey if continuing education staff delivered the training on-site for long distance programs or whether some other delivery system, such as satellite hook-up or the Internet, is used.

Research Question 6: What was the 1998 enrollment in continuing education sponsored corporate contract training?

Table 8 provides the analysis of the findings for 1998 enrollment in continuing education contract training programs.

Table 8

The Estimated Number of Enrollees in Continuing Education Units' Corporate Contract Training Programs

\begin{tabular}{|l|l|l|}
\hline Categories & Respondents $(\mathbf{N}=83)$ & Percentage of Total \\
\hline$<99$ & 16 & $19 \%$ \\
\hline $100-499$ & 30 & $36 \%$ \\
\hline $500-999$ & 10 & $12 \%$ \\
\hline $1,000-2,499$ & 18 & $22 \%$ \\
\hline $2,500-4,999$ & 4 & $5 \%$ \\
\hline $5,000+$ & 5 & $6 \%$ \\
\hline
\end{tabular}

According to the data in Table 8, a large majority (80\%) of continuing education units' corporate training programs reported enrollments of 100 or more annually. The 100-499 category drew the highest percentage of responses (36\%), followed by 1,000 $2,499(22 \%)$. The enrollment category of 99 or fewer was positioned next (19\%). 
Research Question 7: How much revenue is produced by corporate training programs?

Table 9 presents the reported amount of revenue continuing education units produced in 1998 from contract training programs.

\section{Table 9}

Revenue for Continuing Education Units' Corporate Training Programs

\begin{tabular}{|l|l|l|}
\hline Categories & Responses $(\mathbf{N}=\mathbf{8 3})$ & Percentage of Total \\
\hline$\$ 0-249,000$ & 49 & $59 \%$ \\
\hline$\$ 250,000-499,999$ & 8 & $10 \%$ \\
\hline$\$ 500,000-999,999$ & 6 & $7 \%$ \\
\hline$\$ 1$ million -2.49 million & 14 & $17 \%$ \\
\hline$\$ 2.5$ million- 4.99 million & 5 & $6 \%$ \\
\hline$\$ 5$ million or more & 1 & $1 \%$ \\
\hline
\end{tabular}

Sixty-nine percent of all continuing education units' contract training programs produced less than $\$ 500,000$ in revenue annually. Twenty programs, representing a quarter of the respondents, produced more than $\$ 1$-million. One institution in New England reported revenue of $\$ 5$-million or more.

Research Question 8: Are continuing education units increasing or decreasing their involvement in contract training?

The data in Table 10 show the expected future involvement in contract training by university continuing education units.

\section{Table 10}

The Extent to which Continuing Education Units are Increasing or Decreasing Their Involvement in Contract Training

\begin{tabular}{|l|l|l|}
\hline $\begin{array}{l}\text { Has revenue for contract training } \\
\text { programs increased or decreased over } \\
\text { the last 5 years? }\end{array}$ & Respondents (N= 83) & Percentage of Total \\
\hline increased significantly & 30 & $36 \%$ \\
\hline increased some & 32 & $39 \%$ \\
\hline stayed the same & 9 & $11 \%$ \\
\hline decreased some & 6 & $7 \%$ \\
\hline decreased significantly & 2 & $2 \%$ \\
\hline not known & 4 & $5 \%$ \\
\hline
\end{tabular}


Table 10 (continued)

\begin{tabular}{|l|l|l|}
\hline $\begin{array}{l}\text { In the next 5 years, do you } \\
\text { expect the number of corporate } \\
\text { training programs to increase or } \\
\text { decrease? }\end{array}$ & & \\
\hline increase some & 40 & $48 \%$ \\
\hline increase significantly & 38 & $45 \%$ \\
\hline increase some & 40 & $48 \%$ \\
\hline stay the same & 4 & $5 \%$ \\
\hline decrease some & 2 & $2 \%$ \\
\hline decrease significantly & 0 & $0 \%$ \\
\hline
\end{tabular}

Table 10 shows that continuing education units' revenue from contract training programs grew at least some for a majority of respondents (74\%) over the last five years; a third experienced significant growth. Less than $10 \%$ of respondents reported any decrease in programming revenue. Continuing education leaders were optimistic about the future of their contract training programs. An overwhelming majority of respondents anticipated their contract training programs would grow at least some over the next five years (93\%), and nearly half of respondents expected significant increases (45\%). Only 2 percent predicted some decline in programming.

Research Question 9: Are continuing education units satisfied with their corporate contract training programs?

The literature defined some parameters to assess satisfaction such as financial, public relations, academic quality, and program development staff opinion. Table 11 presents the reported findings on these satisfaction measures. A five-point Likert scale, with 5 being the most satisfied, 1 the least satisfied and 3 a neutral rating, was used to measure satisfaction on these four parameters. The total number of respondents for each satisfaction measure is shown in the table. 
Table 11

A Measure of Continuing Education Units' Satisfaction with Their Contract Training Programs

\begin{tabular}{|l|l|l|l|l|l|l|l|}
\hline $\begin{array}{l}\text { Satisfaction } \\
\text { Characteristics }\end{array}$ & $\begin{array}{l}1 \\
\text { (Least) }\end{array}$ & 2 & 3 & 4 & $\begin{array}{l}5 \\
\text { (Most) }\end{array}$ & Mean & $\begin{array}{l}\text { Standard } \\
\text { Deviation }\end{array}$ \\
\hline $\begin{array}{l}\text { Academic } \\
\text { quality }\end{array}$ & 0 & 1 & 12 & 31 & 37 & 4.3 & .84 \\
\hline Program staff & 2 & 6 & 23 & 34 & 16 & 3.7 & .84 \\
\hline Public relations & 1 & 9 & 23 & 35 & 13 & 3.6 & .84 \\
\hline Financial & 8 & 12 & 20 & 26 & 15 & 3.4 & .84 \\
\hline
\end{tabular}

Continuing education units reported being most satisfied with the academic quality of their contract training programs. The overall academic quality satisfaction score was 4.3. Eighty-four percent of respondents gave "satisfied" or higher ratings to academic quality; 46 percent of the respondents were "most satisfied".

Respondents reported the next highest level of satisfaction (mean $=3.7)$ with program staff. Forty-two percent of respondents chose "satisfied", followed by "neutral" (28\%), and "most satisfied" (20\%).

Public relations followed in reported satisfaction with a 3.6 mean score. The most common level of satisfaction chosen by respondents was "satisfied" ( $43 \%)$, followed by "neutral" (28\%), and "most satisfied" (16\%).

Respondents reported a mean satisfaction rating of 3.4 for financial. The responses were much more diffuse on this question than on the other satisfaction characteristic measures. "Satisfied" received the highest percentage of responses (32\%), followed by "neutral" (25\%), and "most satisfied" (19\%). The ratings of "not satisfied" and "least satisfied" received 15 percent and 10 percent of the responses, respectively. Although better than 50 percent were "satisfied" with the financial return from their 
contract training programs, the remaining institutions were "neutral" or less than satisfied.

Research Question 10: What types of corporate training programs do continuing education units offer?

The survey used the Bureau of Labor Statistics definitions of training types to guide the responses. The research instrument allowed respondents to check all programs offered to business and industry in 1998. Table 12 presents the reported types of training offered by continuing education units to business and industry.

Table 12

Types of Training Offered by Continuing Education Units

\begin{tabular}{|l|l|l|}
\hline Types of Training & Respondents $(\mathbf{N}=\mathbf{8 3})$ & Percentage of Total \\
\hline management/supervision & 69 & $83 \%$ \\
\hline computer programming & 56 & $67 \%$ \\
\hline professional/technical & 46 & $55 \%$ \\
\hline communications & 46 & $55 \%$ \\
\hline sales and customer service & 30 & $36 \%$ \\
\hline basic skills & 27 & $33 \%$ \\
\hline service-related & 20 & $24 \%$ \\
\hline awareness & 18 & $22 \%$ \\
\hline occupational safety & 15 & $18 \%$ \\
\hline production and construction & 12 & $14 \%$ \\
\hline clerical and administrative & 11 & $13 \%$ \\
\hline orientation & 4 & $5 \%$ \\
\hline health and wellness & 1 & $1 \%$ \\
\hline other & 17 & $20 \%$ \\
\hline
\end{tabular}

Continuing education units provided a variety of contract training programs to business and industry. Management/supervision (83\%), computer programming (67\%), professional/technical (55\%), and communications (55\%) were the programs most often delivered programs to business and industry. Sales and customer service (36\%) and basic 
skills (33\%) followed. The three least common offerings were health and wellness (1\%), orientation (5\%), and clerical and administrative (13\%).

The "other" category received a 20 percent response rate. The most often mentioned "other" programs included telecommunications $(\mathrm{N}=3)$, executive leadership $(\mathrm{N}=2)$, and project management $(\mathrm{N}=2)$. Additional areas of training mentioned included public policy, language skill training, cultural training, web development, training and development, and data acquisitions.

Research Question 11: What type of training does business and industry most commonly request?

Table 13 provides the most commonly requested training programs by business and industry.

Table 13

Contract Training Programs in Most Demand from Continuing Education Units

\begin{tabular}{|l|l|l|}
\hline Types of Training & Respondents (N= 83) & Percentage of Total \\
\hline management/supervision & 50 & $60 \%$ \\
\hline computer programming & 45 & $54 \%$ \\
\hline communications & 40 & $48 \%$ \\
\hline professional/technical & 29 & $35 \%$ \\
\hline sales and customer service & 17 & $20 \%$ \\
\hline basic skills & 13 & $16 \%$ \\
\hline production and construction & 10 & $12 \%$ \\
\hline occupational safety & 9 & $11 \%$ \\
\hline service-related & 8 & $10 \%$ \\
\hline awareness & 6 & $7 \%$ \\
\hline health and wellness & 4 & $5 \%$ \\
\hline clerical and administrative & 3 & $4 \%$ \\
\hline orientation & 2 & $2 \%$ \\
\hline other & 7 & $8 \%$ \\
\hline
\end{tabular}

Based on the data in Table 13, the programs most demanded by business and industry from continuing education units were management/supervision (60\%), computer 
programming (54\%), communications (48\%), and professional/ technical (35\%).

Business and industry demonstrated little demand from continuing education units for orientation (2\%), clerical and administrative (4\%), health and wellness (5\%), and awareness (7\%) training programs. The "other" responses included business requests for training in internet-web development, telecommunications, data acquisitions, government accounting, project management, language training, and executive leadership.

The top responses to the most requested types of training were consistent with the training programs offered responses; however, the total demand percentages were consistently smaller than percentages for each highly ranked type of training. For example, the professional/technical area was offered in 55 percent of the cases by continuing education but was only demanded 35 percent of the time by business and industry. Management and supervision showed the same tendency. Continuing education units offered management and supervision 83 percent of the time, but were demanded by business and industry only 60 percent of the time.

Question 12: What level of employee do continuing education units' contract training programs most often serve?

Table 14 presents the findings for what level of employee continuing education training programs serve most.

Table 14

The Level of Employee Continuing Education Contract Training Programs are Serving

\begin{tabular}{|l|l|l|}
\hline Level of Employee & Respondents $\left.{ }^{*} \mathbf{N}=\mathbf{6 1}\right)$ & Percentage of Total \\
\hline executive (VP and above) & 0 & $0 \%$ \\
\hline middle manager & 28 & $46 \%$ \\
\hline professional/technical & 22 & $36 \%$ \\
\hline $1^{\text {st }}$ level manager & 10 & $16 \%$ \\
\hline administrative/secretarial & 0 & $0 \%$ \\
\hline not known & 1 & $2 \%$ \\
\hline
\end{tabular}


*The question asked the respondents to check only one level of employee. Twenty-two respondents checked more than one choice and therefore were excluded from the analysis, decreasing the total number of respondents to 61 .

According to the data in Table 14, continuing education units' contract training programs served employees in the middle of the business hierarchy. The large majority of continuing education contract training programs served middle managers $(46 \%)$, professional/technical workers (36\%), and first level managers $(16 \%)$. These three groups combined for 98 percent of the responses. None of the programs reported serving administrative/secretarial or executive level employees.

Research Question 13: What size companies are seeking corporate training services?

Table 15 presents the size of company that continuing education is serving with contract training.

Table 15

The Size of Company Seeking Continuing Education Units' Contract Training Services

\begin{tabular}{|l|l|l|}
\hline $\begin{array}{l}\text { Company Size Based on Number of } \\
\text { Employees }\end{array}$ & Respondents (N=83) & Percentage of Total \\
\hline $0-20$ & 1 & $1 \%$ \\
\hline $21-49$ & 3 & $4 \%$ \\
\hline $50-99$ & 9 & $11 \%$ \\
\hline $100-499$ & 16 & $19 \%$ \\
\hline $500-999$ & 13 & $16 \%$ \\
\hline $1,000-2,499$ & 16 & $19 \%$ \\
\hline 2,500 and above & 17 & $20 \%$ \\
\hline not known & 8 & $10 \%$ \\
\hline
\end{tabular}

Continuing education units' contract training programs served primarily companies with 100 or more employees (75\%). Twenty-percent of programs served the 2,500 and above category, 19 percent of programs served each of the 1,000-2,499 and 100-499 categories, and 16 percent served the 500-999 category. Only 15 percent of the respondents reported serving companies with 100 or fewer employees. 
Research Question 14: What types of businesses are seeking training services from continuing education units?

The survey used the Bureau of Labor Statistics definitions of business sectors to guide the responses. The research instrument allowed respondents to check any program offered to business and industry in 1998 . Table 16 presents the reported data to the questions related to business sectors served, sectors with the most contracts, and sectors yielding the most revenue. The table is rank ordered by the responses to the question concerning "sectors served by continuing education units." Also, note that the percentages down the columns exceed 100 percent because respondents were able to choose multiple responses.

Table 16

The Business Sectors Served by Continuing Education Units' Contract Training Programs

\begin{tabular}{|l|l|l|l|l|l|l|}
\hline $\begin{array}{l}\text { Sectors of } \\
\text { Companies }\end{array}$ & $\begin{array}{l}\text { Sectors Served by } \\
\text { CE's (N=83) }\end{array}$ & $\begin{array}{l}\text { Most Number of } \\
\text { Contracts (N=83) }\end{array}$ & \multicolumn{2}{l|}{$\begin{array}{l}\text { Largest Revenue } \\
\text { Producing Sector (N=83) }\end{array}$} \\
\hline manufacturing & 46 & $55 \%$ & 26 & $31 \%$ & 21 & $25 \%$ \\
\hline health services & 36 & $43 \%$ & 9 & $11 \%$ & 6 & $7 \%$ \\
\hline $\begin{array}{l}\text { information } \\
\text { technology }\end{array}$ & 34 & $41 \%$ & 19 & $23 \%$ & 17 & $20 \%$ \\
\hline finance & 32 & $39 \%$ & 6 & $7 \%$ & 7 & $8 \%$ \\
\hline other & 27 & $33 \%$ & 16 & $19 \%$ & 10 & $12 \%$ \\
\hline utilities & 26 & $31 \%$ & 5 & $6 \%$ & 3 & $4 \%$ \\
\hline insurance & 23 & $28 \%$ & 4 & $5 \%$ & 3 & $4 \%$ \\
\hline services & 22 & $27 \%$ & 6 & $7 \%$ & 4 & $5 \%$ \\
\hline retail & 21 & $25 \%$ & 2 & $2 \%$ & 2 & $2 \%$ \\
\hline construction & 18 & $22 \%$ & 3 & $4 \%$ & 3 & $4 \%$ \\
\hline transportation & 16 & $19 \%$ & 2 & $2 \%$ & 1 & $1 \%$ \\
\hline $\begin{array}{l}\text { chemical and } \\
\text { petroleum }\end{array}$ & 15 & $18 \%$ & 4 & $5 \%$ & 5 & $6 \%$ \\
\hline pharmaceutical & 14 & $17 \%$ & 6 & $7 \%$ & 4 & $5 \%$ \\
\hline communications & 14 & $17 \%$ & 3 & $4 \%$ & 2 & $2 \%$ \\
\hline publishing & 9 & $11 \%$ & 0 & $0 \%$ & 0 & $0 \%$ \\
\hline conglomerate & 8 & $10 \%$ & 2 & $2 \%$ & 1 & $1 \%$ \\
\hline mining & 6 & $7 \%$ & 2 & $2 \%$ & 1 & $1 \%$ \\
\hline
\end{tabular}


Continuing education units were serving all sectors of business and industry. Manufacturing (55\%), health services (43\%), and information technology (41\%) were the most commonly served sectors. Receiving over 30 percent of the responses were finance (39\%), other (33\%), and utilities (31\%) sectors. The most common "other" responses included government, defense industry, agribusiness, and consulting firms. Mining (7\%), conglomerate $(10 \%)$, and publishing $(11 \%)$ were least likely to use continuing education units for training.

Continuing education units contracted most frequently with the manufacturing (31\%) and information technology (23\%) sectors. The only sectors to receive more than 20 percent of the responses. Of the remaining thirteen sectors, only health services (11\%) received more than 10 percent of the responses. With the size and breadth of the United States economy and with the complexity and diversity of local and regional economies, the apportioning of responses was not unexpected. Even with fifteen sector choices, 19 percent of the respondents chose "other." The most common "other" responses included government, consulting firms, international business groups, multi-media, agribusiness, the military, and defense industry.

The manufacturing and information technology sectors also ranked first and second on the question related to the sector that produced the largest revenue stream. This finding was consistent with the results found in the sectors served and numbers of contract questions.

Despite continuing education units' strong contract relationship with the health services sector (43\%), this sector ranked considerably lower in both the frequency and revenue questions. The findings suggest that the health industry, although a prevalent part 
of every community's economy, has modest training needs from university continuing education units.

Research Question 15: What university benefits are derived from offering training programs to business and industry?

As shown is Table 17, continuing education units conducted contract training programs for both tangible benefits, such as revenue, and intrinsic benefits, such as fulfillment of institutional mission.

Table 17

$\underline{\text { Institutional Benefits Derived from Continuing Education Contract Training Programs }}$

\begin{tabular}{|l|l|l|}
\hline Benefits & Respondents (N=83) & Percent of Total \\
\hline $\begin{array}{l}\text { improved relationship with business } \\
\text { community }\end{array}$ & 74 & $89 \%$ \\
\hline increased revenue & 66 & $80 \%$ \\
\hline $\begin{array}{l}\text { beneficial public relations for } \\
\text { continuing education }\end{array}$ & 57 & $69 \%$ \\
\hline fulfillment of mission & 55 & $66 \%$ \\
\hline $\begin{array}{l}\text { increased enrollment in other } \\
\text { continuing education programs }\end{array}$ & 40 & $48 \%$ \\
\hline $\begin{array}{l}\text { opportunity to provide "real world" } \\
\text { contact to faculty }\end{array}$ & 34 & $41 \%$ \\
\hline $\begin{array}{l}\text { increased and enhanced visibility } \\
\text { leading to greater internal support }\end{array}$ & 30 & $36 \%$ \\
\hline internship opportunities for students & 18 & $22 \%$ \\
\hline increased corporate giving & 13 & $16 \%$ \\
\hline equipment from business and industry & 12 & $14 \%$ \\
\hline increased research funding & 7 & $8 \%$ \\
\hline Student placement & 4 & $5 \%$ \\
\hline Other & 2 & $2 \%$ \\
\hline
\end{tabular}

A vast majority of programs reported receiving both kinds of benefits. Most institutions have improved their relationship with the business community through their contract training programs $(89 \%)$. The second ranked benefit was increased revenue for the institution ( $80 \%)$, followed by beneficial public relations (69\%), and fulfillment of mission (66\%). The next tier of highly rated benefits included increased enrollment for 
other programs (48\%) and opportunity to provide faculty with "real world" contact (41\%). Student placement (5\%), research funds (8\%), and equipment from business and industry $(14 \%)$ ranked at the bottom of responses for benefits.

Research Question 16: What problems and barriers limit universities from providing corporate training programs?

Table 18 presents the problems and barriers universities face in delivering contract training programs to business and industry.

Table 18

Identified Barriers to Delivering Contract Training

\begin{tabular}{|l|l|l|}
\hline Barriers & Respondents (N=83) & Percentage of Total \\
\hline $\begin{array}{l}\text { lack of time to develop training } \\
\text { programs }\end{array}$ & 33 & $40 \%$ \\
\hline lack of qualified instructors & 29 & $35 \%$ \\
\hline time constraints of other programs & 27 & $33 \%$ \\
\hline inability to properly market programs & 27 & $33 \%$ \\
\hline lack of internal support & 25 & $30 \%$ \\
\hline $\begin{array}{l}\text { CE not seen as a provider of contract } \\
\text { training }\end{array}$ & 21 & $25 \%$ \\
\hline inadequate facilities & 17 & $20 \%$ \\
\hline attitude of top leadership & 15 & $18 \%$ \\
\hline attitude of corporate executives & 13 & $16 \%$ \\
\hline $\begin{array}{l}\text { poor coordination by state and local } \\
\text { agencies }\end{array}$ & 5 & $6 \%$ \\
\hline difficulty scheduling courses & 4 & $5 \%$ \\
\hline other & 15 & $18 \%$ \\
\hline
\end{tabular}

According to the data in Table 18, the most highly ranked barriers to delivering contract training were all internal continuing education unit issues, such as time to develop programs (40\%), lack of qualified instructors (35\%), inability to market programs (33\%), time constraints of other programs (33\%), and lack of internal support $(30 \%)$. External environmental issues such as attitude of corporate executives (16\%) or poor coordination by state and federal agencies $(6 \%)$ received much less attention. The 
most prevalent external environmental barrier chosen by respondents was "CE's are not seen as a provider of contract training"( $25 \%)$. Responses to the "other" category included lack of incentives for faculty to participate, competition from other internal units (i.e., graduate business school), campus policies and procedures, competition from other vendors, slow turnaround of course development, inability to customize training on-site, lack of centrality to the university mission, and financial limitations.

Research Question 17: What characteristics facilitate effective corporate training programs between business and higher education?

Table 19 presents the findings for what characteristics facilitate effective corporate contract training programs.

Table 19

Characteristics of Successful Continuing Education Contract Training Programs to Business and Industry

\begin{tabular}{|l|l|l|}
\hline Success Characteristics & Respondents (N=83) & Percentage of Total \\
\hline talented personnel & 67 & $81 \%$ \\
\hline curriculum development & 57 & $69 \%$ \\
\hline delivery & 54 & $65 \%$ \\
\hline marketing & 51 & $61 \%$ \\
\hline $\begin{array}{l}\text { defined processes, systems } \\
\text { and procedures to carry out } \\
\text { contract training programs }\end{array}$ & 40 & $48 \%$ \\
\hline $\begin{array}{l}\text { previous relationship with } \\
\text { business community }\end{array}$ & 39 & $47 \%$ \\
\hline $\begin{array}{l}\text { evaluation and follow-up } \\
\text { procedures }\end{array}$ & 36 & $43 \%$ \\
\hline $\begin{array}{l}\text { internal commitment of } \\
\text { financial resources, } \\
\text { including personnel, } \\
\text { equipment, and facilities }\end{array}$ & 31 & $37 \%$ \\
\hline $\begin{array}{l}\text { involvement of senior level } \\
\text { management in program }\end{array}$ & 27 & $33 \%$ \\
\hline federal and state grants & 9 & $11 \%$ \\
\hline other & 5 & $6 \%$ \\
\hline
\end{tabular}


Based on the findings in Table 19, the characteristics ranked highest in facilitating successful partnerships included talented personnel (81\%), curriculum development (69\%), delivery $(65 \%)$, and marketing $(61 \%)$. Several other characteristics received significant notice, including defined processes (48\%), previous business relationship (47\%), evaluation and follow up procedures (43\%), followed by internal commitment (37\%) and involvement of senior level management (33\%). Federal and state agencies were mentioned as an influence on success by only 11 percent of respondents.

The "other" responses included custom tailored training programs, entrepreneurial leadership, cost-effective training, quality programming, faculty commitment, and seen as a core business activity and resources allocated as such.

\section{Summary of Findings to the Research Questions}

Continuing education units conducted contract training with business and industry to fulfill part of its mission, produce needed revenue, and meet demand from the business community. The funding to offer contract training comes primarily through the revenue generated from the training contracts, with institutional support coming in the form of physical and capital resources or some combination of capital, physical, and financial resources.

Most institutions dedicated three or fewer full-time staff to manage 11 or more contracts. Over one-fifth of the programs, however, supported more than four staff and 51 or more contracts a year. Nearly 60 percent of the contract training programs produced annual revenue of less than $\$ 249,999$. A quarter of the programs produced $\$ 1$ million or more.

The programs had enrollments ranging from fewer than 99 to over 5,000 students per year. Over 50 percent provided training to 500 or fewer participants each year. 
Thirty-three percent served over 1,000 students. A large majority of contract training programs served businesses within a 100-mile radius of campus.

Three-quarters of institutions experienced some increase in their contract training programs in the last five years. Ninety-three percent of the respondents expected an even greater increase in the next five years.

Continuing education units were most satisfied with the academic quality of their contract training programs. Institutions were least satisfied with the financial return from their contract training programs.

Continuing education provided a broad range of training programs to business and industry. Manufacturing, health services, information technology, and finance sectors were most likely to seek university continuing education units' contract training services. Manufacturing and information technology sectors entered the greatest number of contracts and provided the largest revenue producing contracts. Seventy-one percent of the companies served by continuing education contract services had employee bases of 100 or more.

The most prevalent training programs offered were management/supervision, computer programming, communications, and professional/technical. The same set of courses was the most requested training by business and industry. Middle managers and professional/technical workers received over 80 percent of the training provided by continuing education units.

Continuing education units derived many benefits from their contract training programs. The most highly ranked benefits were improved relationship with the business community, revenue for the institution, positive public relations, and fulfillment of 
mission. The barriers chosen most frequently by respondents focused on internal resource issues such as time to develop programs, lack of qualified instructors, inability to market programs, time constraints of other programs, and lack of internal support.

Correspondingly, the most highly ranked characteristics of successful programs also were focused internally. This list included talented personnel, curriculum development, delivery, and marketing.

\section{Profile Comparisons}

The following section will summarize and analyze comparison profiles based on institutional type, size, classification, and location. Each comparison begins with an analysis of the demographic data. The demographics provide the framework for further analysis of continuing education contract training programs. This analysis of the type, organizational style, enrollment, and location helps define the culture, programs, resources, and organizational structure of institutions. The differences in institutional demographics influence the continuing education units' opportunity to offer contract training programs to the business community. For example, urban institutions face greater competition from other vendors, but are also likely to have a larger and more diverse business community in which to offer contract training services. Conversely, a small city setting gives continuing education an opportunity to acquire a large share of the training market for certain types of training, especially training based on information and knowledge.

Profile comparisons of public and private universities, institutions with enrollments of 10,000-19,999 and 20,000 or more, research and doctoral-granting universities, and small city and urban institutions were conducted to provide a more 
comprehensive examination of the data. The program comparisons were conducted on research questions related to: reasons for supporting contract training, how programs are funded, institutional support, revenue produced, average number of contracts, satisfaction level, types of programs offered, business sectors seeking services, training programs demanded by business and industry, sectors with most contracts, the sector producing the most revenue, expectations of future growth, benefits, barriers and characteristics of successful programs.

The comparisons focus on both the similarities and differences among the groups. Each comparison provides a narrative of the findings, followed by a table with the supporting data. The table provides the research question in the first column, followed by a comparison of the most highly ranked responses to each question and the percentage of total responses. Each comparison section closes with a summary of the significant findings.

A Comparison of Public and Private Contract Training Programs

Table 20 and Table 21 present the demographic and survey data comparison between public and private universities.

Table 20

Demographic Comparison Public and Private University Contract Training Programs

\begin{tabular}{|l|l|l|}
\hline Institutional Demographics & Public (N=73) & Private (N=38) \\
\hline Carnegie Type & & \\
Research I or II & $63 \%$ & $55 \%$ \\
Doctoral I or II & $34 \%$ & $45 \%$ \\
& & \\
\hline
\end{tabular}


Table 20 (continued)

\begin{tabular}{|l|l|l|}
\hline Organizational type & $37 \%$ \\
$\begin{array}{l}\text { academically decentralized/ } \\
\text { administratively } \\
\text { decentralized }\end{array}$ & $18 \%$ & $16 \%$ \\
$\begin{array}{l}\text { academically centralized/ } \\
\text { administratively centralized }\end{array}$ & $46 \%$ & \\
\hline Enrollment & $48 \%$ & $8 \%$ \\
20,000 or more & $38 \%$ & $46 \%$ \\
$10,000-19,999$ & & \\
\hline Location & $41 \%$ & $84 \%$ \\
Small City & $45 \%$ & \\
Urban & \multicolumn{2}{|l}{} \\
\hline
\end{tabular}

Public universities were slightly more likely than private universities to be Carnegie classified Research I or II institutions (63\% to 55\%). Private institutions were more likely to be academically decentralized and administratively decentralized (37\%), than public institutions (18\%), which were much more inclined to be academically centralized and administratively centralized than private institutions ( $46 \%$ to $16 \%)$. Public institutions were much more likely to have enrollments of 20,000 or more ( $48 \%$ to $8 \%)$. Private institutions were much more likely to be located in an urban setting ( $84 \%$ to 45\%). Public institutions, on the other hand, were three times more likely to be located in a small city $(41 \%$ to $11 \%)$.

Table 21 presents the survey comparison between public and private university contract training programs. 
Table 21

Comparison Public and Private University Contract Training Programs

\begin{tabular}{|c|c|c|}
\hline Survey Responses & Public & Private \\
\hline Respondents & 73 & 38 \\
\hline with programs & 58 & 25 \\
\hline without programs & 15 & 13 \\
\hline Percent with programs & $80 \%$ & $66 \%$ \\
\hline $\begin{array}{l}\text { Top reasons CE involved in } \\
\text { Contract training }\end{array}$ & $\begin{array}{l}\text { (85\%)Component of CE } \\
\text { mission } \\
\text { (71\%)Part of institution } \\
\text { service mission } \\
(71 \%) \text { Business demand }\end{array}$ & $\begin{array}{l}(84 \%) \text { Component of CE } \\
\text { mission } \\
(80 \%) \text { Revenue for } \\
\text { institution } \\
(56 \%) \text { Business demand } \\
(40 \%) \text { Institutional mission }\end{array}$ \\
\hline How training is funded & $\begin{array}{l}(90 \%) \text { Training contracts } \\
\text { only }\end{array}$ & $\begin{array}{l}\text { (44\%) Training contracts } \\
\text { only } \\
(44 \%) \text { Combination of } \\
\text { institutional budget and } \\
\text { contracts }\end{array}$ \\
\hline $\begin{array}{l}\text { University support for } \\
\text { program }\end{array}$ & $\begin{array}{l}\text { (41\%) Physical and capital } \\
\text { resources } \\
(34 \%) \text { Combination }\end{array}$ & $\begin{array}{l}(48 \%) \text { Combination } \\
(24 \%) \text { Physical and capital } \\
\text { resources }\end{array}$ \\
\hline $\begin{array}{l}\text { Revenue produced from } \\
\text { contracts }\end{array}$ & $\begin{array}{l}(57 \%) \$ 0-249,999 \\
(19 \%) \text { \$1million - } 2.49\end{array}$ & $\begin{array}{l}(60 \%) \$ 0-249,999 \\
(20 \%) \$ 250,000-499,000\end{array}$ \\
\hline Average number of contracts & $\begin{array}{l}\text { (29\%) } 11-25 \text { contracts } \\
(22 \%) 1-10 \text { contracts }\end{array}$ & $\begin{array}{l}(76 \%) 1-10 \text { contracts } \\
(8 \%) 11-25 \text { contracts }\end{array}$ \\
\hline $\begin{array}{l}\text { Satisfaction level } \\
\text { Financial } \\
\text { Public relations } \\
\text { Academic quality } \\
\text { Program development staff }\end{array}$ & $\begin{array}{l}3.3 \\
3.4 \\
4.0 \\
3.5\end{array}$ & $\begin{array}{l}3.4 \\
3.5 \\
4.3 \\
3.4\end{array}$ \\
\hline Types of programs offered & $\begin{array}{l}\text { (90\%) Mgement/supervision } \\
(69 \%) \text { Computer } \\
\text { (67\%) Prof/tech }\end{array}$ & $\begin{array}{l}\text { (64\%) Mgement/supervision } \\
(60 \%) \text { Computer } \\
(48 \%) \text { Communications }\end{array}$ \\
\hline
\end{tabular}


Table 21 (continued)

\begin{tabular}{|c|c|c|}
\hline Programs demanded & $\begin{array}{l}\text { (67\%) Mgement/supervision } \\
(53 \%) \text { Computers }\end{array}$ & $\begin{array}{l}\text { (64\%) Computers } \\
\text { (44\%) Mgement/supervision }\end{array}$ \\
\hline Sectors seeking contracts & $\begin{array}{l}\text { (60\%) Manufacturing } \\
(53 \%) \text { Health } \\
(43 \%) \text { Finance }\end{array}$ & $\begin{array}{l}\text { (52\%) Info. Tech } \\
(40 \%) \text { Manufacturing }\end{array}$ \\
\hline Sector with most contracts & (38\%) Manufacturing & (28\%) Info. Tech \\
\hline $\begin{array}{l}\text { Sector producing most } \\
\text { revenue }\end{array}$ & (31\%) Manufacturing & (20\%) Info. Tech \\
\hline $\begin{array}{l}\text { Program experiencing } \\
\text { increasing or decreasing } \\
\text { demand }\end{array}$ & $\begin{array}{l}\text { (41\%) increasing some } \\
(48 \%) \text { increasing } \\
\text { significantly }\end{array}$ & $\begin{array}{l}(68 \%) \text { increasing some } \\
(28 \%) \text { increasing } \\
\text { significantly }\end{array}$ \\
\hline Benefits & $\begin{array}{l}(91 \%) \text { Improved business } \\
\text { relationships } \\
(72 \%) \text { Revenue for program } \\
(72 \%) \text { Public relations for } \\
\text { CE program } \\
(70 \%) \text { Supports mission }\end{array}$ & $\begin{array}{l}(92 \%) \text { Revenue for program } \\
(80 \%) \text { Improved business } \\
\text { relationships } \\
(56 \%) \text { Public relations for } \\
\text { CE program }\end{array}$ \\
\hline Barriers & $\begin{array}{l}\text { (41\%) Program } \\
\text { development } \\
(36 \%) \text { Marketing } \\
(34 \%) \text { Internal support }\end{array}$ & $\begin{array}{l}\text { (52\%) Demands of other } \\
\text { programs } \\
\text { (44\%) Lack of qualified } \\
\text { instructors }\end{array}$ \\
\hline $\begin{array}{l}\text { Characteristics of successful } \\
\text { programs }\end{array}$ & $\begin{array}{l}\text { (77\%) Talent } \\
(66 \%) \text { Curriculum } \\
\text { development } \\
(64 \%) \text { Marketing }\end{array}$ & $\begin{array}{l}(84 \%) \text { Talent } \\
(68 \%) \text { Curriculum } \\
\text { development } \\
(68 \%) \text { Delivery }\end{array}$ \\
\hline
\end{tabular}

Public and private university contract training programs resembled each other in a number of respects including their reasons for offering contract training, types of programs offered, and characteristics of successful programs. Both types of institutions chose "a component of continuing education mission" as the top ranked reason for offering contract training. However, seventy-one percent of public institutions reported that contract training was part of their institutional service mission, while only 40 percent 
of privates responded this way. Management and computer training were ranked as the most prevalent types of programs offered. Public and private institutions also chose talent and curriculum development as primary characteristics of successful contract training programs.

Public and private institutions differed on a number of research questions, including percent of institutions with a contract training programs, how training programs are funded, revenue and number of contracts, sectors seeking contracts, sectors with most contracts, sectors that produce the most revenue, top ranked benefit, and barriers. In general, public institutions conducted larger, more autonomous contract training programs than private institutions. Eighty percent of public institutions reported supporting contract training programs, as compared to 66 percent of private institutions. Public universities relied almost entirely on training contracts (90\%), while private institutions reported receiving institutional budget support in nearly half the cases (44\%).

Although public and private institutions were similar in the percentages of programs producing revenue of $\$ 0-249,000,57$ percent and 60 percent respectively, public institutions' next highest ranked category of revenue was $\$ 1$-million to 2.49 million (19\%). The next ranked revenue category for private universities was $\$ 250,000$ to $499,999(20 \%)$. The research question regarding average number of contracts reflected a similar finding. A majority of private institutions managed 1-10 contracts annually (76\%). This compares to public universities, which managed $1-10$ contracts $(22 \%), 11-25$ contracts (29\%), 51-100 contracts (17\%), and 26-50 contracts (16\%), Despite the size differential, private institutions reported a slightly higher financial satisfaction rating (3.4) than public institutions (3.3). 
Programming and business sector interests were different for public and private institutions. Management/supervision ranked at the top of both lists for programs offered, yet public universities offered management/supervision in 90 percent of the cases, compared to 64 percent at private institutions. Computer training followed for both types, however, public institutions then ranked professional/technical training third (67\%), while private institutions ranked communications third (48\%). Computer training was the most frequently demanded program by businesses from private institutions; management/supervision was the most frequently demanded program from public institutions.

The manufacturing sector sought the most contracts and produced the most revenue from public universities. The health and finance sectors followed closely behind. The information technology sector produced the most revenue and largest number of contracts for private institutions. The manufacturing sector ranked second.

Almost 90 percent of public and private institutions expected their programs to continue to grow over the next five years. Private university respondents overall were more optimistic (96\%) than public institutions (89\%) about the future growth of their contact training programs. Sixty-eight percent of private institutions reported an expectation of "some increase" and 28 percent expected "significant increases" in their programs. Forty-eight percent of the public institutions reported that "significant increases" were ahead and 41 percent responded that "some increases" were expected. Public and private institutions reported that public relations for the continuing education program, improved business relationships, and revenue for the program were important benefits. However, private universities ranked revenue for the program (92\%) 
significantly higher than public institution programs (72\%). Public universities ranked improved business relationships as most important (91\%), compared to private institutions (80\%).

Public and private institutions ranked internal environmental barriers as most problematic to running a successful contract training program. Public universities found program development, marketing, and internal support as the greatest barriers, while private institutions reported demands of other programs and lack of qualified instructors as most problematic to their success.

In summary, public and private continuing education units' contract training programs differed in a number of ways. Public institutions were more likely to have contract training programs that managed a greater number of training contracts and produced more revenue annually than private institutions. Private institutions were more likely to serve the information technology sector, while public universities served the manufacturing sector. Private institutions were more revenue driven than their public counterparts, which ranked serving their institutional mission more highly. Private institutions found barriers in demands from other programs and finding qualified instructors, but were more optimistic about the future growth of their contract training programs than public institutions. Public institutions found improved business relationships to be the greatest benefit, and program development, marketing and internal support to be the greatest barriers to success.

Public and private institutions were similar on purpose for providing contract training services, type of training offered and characteristics of success. Both reported that the continuing education mission was the primary reason for offering contract 
training services to business and industry. Management/supervision and computer training were the programs most offered and demanded. Public and private universities also reported that talent and curriculum development were most important to their contract training programs success.

A Comparison of Contract Training Programs based on Institutional Enrollments

This section compares institutions with enrollments of 10,000-19,999 and 20,000 or more. Table 22 and Table 23 present the comparative data of these two categories.

Table 22 provides the demographic analysis and Table 23 the survey question analysis.

Table 22

Demographic Comparison of Contract Training Programs based on Enrollment Size

\begin{tabular}{|c|c|c|}
\hline Institutional Demographics & $10,000-19,999(\mathrm{~N}=47)$ & 20,000 or more $(\mathrm{N}=39)$ \\
\hline Respondents & 47 & 39 \\
\hline with programs & 36 & 30 \\
\hline without programs & 11 & 9 \\
\hline Percent with programs & $77 \%$ & $77 \%$ \\
\hline Carnegie Type & & \\
\hline $\begin{array}{l}\text { Research I or II } \\
\text { Doctoral I or II }\end{array}$ & $\begin{array}{l}74 \% \\
26 \%\end{array}$ & $\begin{array}{l}77 \% \\
23 \% \\
\end{array}$ \\
\hline Organizational type & & \\
\hline $\begin{array}{l}\text { academically decentralized/ } \\
\text { administratively decentralized }\end{array}$ & $28 \%$ & $21 \%$ \\
\hline $\begin{array}{l}\text { academically centralized/ } \\
\text { administratively centralized }\end{array}$ & $15 \%$ & $33 \%$ \\
\hline $\begin{array}{l}\text { academically decentralized/ } \\
\text { administratively centralized }\end{array}$ & $49 \%$ & $36 \%$ \\
\hline
\end{tabular}


Table 22 (continued)

\begin{tabular}{|l|l|l|}
\hline Institutional Type & $61 \%$ & $90 \%$ \\
Public & $39 \%$ & $10 \%$ \\
Private & & \\
\hline Location & $30 \%$ & $38 \%$ \\
Small City & $60 \%$ & $49 \%$ \\
Urban & & \\
\hline
\end{tabular}

Institutions with enrollments of $10,000-19,999$ and 20,000 or more supported contract training programs at the same level (77\%). The demographics for these two types of institutions reported similar Carnegie classifications. Seventy-four percent of institutions enrolling 10,000-19,999 and 77 percent of 20,000 or more were Research I or II. Institutions with enrollments of 10,000-19,999 and 20,000 or more institutions also resembled each other in location.

Institutions with enrollments of 10,000-19,999 were slightly more likely to be located in urban settings than institutions with enrollments of 20,000 or more $(60 \%$ to $49 \%$ ). Conversely, institutions with enrollments of 20,000 were more likely found in small cities ( $38 \%$ to $30 \%)$.

Institutions with enrollments of 20,000 or more were more likely to be academically centralized and administratively centralized (33\% to $15 \%)$ than universities with enrollment of $10,000-19,999$, which were more inclined to be academically decentralized and administratively centralized (49\% to $36 \%)$. Institutions with enrollments of 20,000 or more were much more likely to be public institutions $(90 \%$ to $61 \%)$ 
Table 23 presents the comparison of contract training programs based on

enrollment size.

Table 23

Comparison of Contract Training Programs based on Enrollment

$\underline{\text { Size }}$

\begin{tabular}{|c|c|c|}
\hline Survey Responses & $10,000-19,999$ & 20,000 or more \\
\hline $\begin{array}{l}\text { Top reasons CE involved in } \\
\text { Contract training }\end{array}$ & $\begin{array}{l}\text { (86\%) Component of CE } \\
\text { mission } \\
(80 \%) \text { Revenue for } \\
\text { institution } \\
(67 \%) \text { Business demand } \\
(55 \%) \text { Institutional } \\
\text { mission }\end{array}$ & $\begin{array}{l}(90 \%) \text { Component of } \mathrm{CE} \\
\text { mission } \\
(77 \%) \text { Institutional mission } \\
(73 \%) \text { Revenue for } \\
\text { institution }\end{array}$ \\
\hline How training is funded & $\begin{array}{l}\text { (54\%) Training contracts } \\
\text { only } \\
(28 \%) \text { Combination of } \\
\text { institutional budget and } \\
\text { contracts }\end{array}$ & $\begin{array}{l}\text { (75\%) Training contracts } \\
\text { only } \\
(13 \%) \text { Combination of } \\
\text { institutional budget and } \\
\text { contracts }\end{array}$ \\
\hline $\begin{array}{l}\text { University support for } \\
\text { program }\end{array}$ & $\begin{array}{l}\text { (42\%) Combination } \\
(36 \%) \text { Physical and } \\
\text { capital resources }\end{array}$ & $\begin{array}{l}\text { (43\%) Physical and capital } \\
\text { resources } \\
(37 \%) \text { Combination }\end{array}$ \\
\hline Average number of contracts & (44\%) $1-10$ contracts & ( $37 \%) 11-25$ contracts \\
\hline Average annual revenue & $\begin{array}{l}(55 \%) \$ 0-249,000 \\
(19 \%) \$ 250,000-499,999 \\
(17 \%) \$ 1-2.49 \text { million }\end{array}$ & $\begin{array}{l}(60 \%) \$ 0-249,000 \\
(20 \%) \$ 1-2.49 \text { million }\end{array}$ \\
\hline $\begin{array}{l}\text { Satisfaction level } \\
\text { Financial } \\
\text { Public relations } \\
\text { Academic quality } \\
\text { Program development staff }\end{array}$ & $\begin{array}{l}3.6 \\
3.8 \\
4.3 \\
3.6 \\
\end{array}$ & $\begin{array}{l}2.9 \\
3.2 \\
3.9 \\
3.4 \\
\end{array}$ \\
\hline Types of programs offered & $\begin{array}{l}\text { (75\%)Mgemt/supervision } \\
(64 \%) \text { Computer } \\
(56 \%) \text { Communications }\end{array}$ & $\begin{array}{l}\text { (93\%) Mgemt/supervision } \\
\text { (73\%) Prof/tech } \\
\text { (73\%) Computer }\end{array}$ \\
\hline
\end{tabular}


Table 23 (continued)

\begin{tabular}{|c|c|c|}
\hline Programs demanded & $\begin{array}{l}\text { (64\%) Communications } \\
(53 \%) \mathrm{Mgemt} / \text { supervision }\end{array}$ & $\begin{array}{l}(73 \%) \mathrm{Mgemt} / \text { supervision } \\
(57 \%) \text { Computers }\end{array}$ \\
\hline Sectors seeking contracts & $\begin{array}{l}\text { (58\%) Manufacturing } \\
(39 \%) \text { Info. Tech } \\
(36 \%) \text { Finance/Insurance }\end{array}$ & $\begin{array}{l}\text { (53\%) Manufacturing } \\
(47 \%) \text { Health } \\
(43 \%) \text { Info. Tech }\end{array}$ \\
\hline Sector with most contracts & (31\%) Manufacturing & (30\%) Manufacturing \\
\hline $\begin{array}{l}\text { Sector producing most } \\
\text { revenue }\end{array}$ & (31\%) Manufacturing & $\begin{array}{l}\text { (23\%) Manufacturing } \\
(20 \%) \text { Info. Tech }\end{array}$ \\
\hline $\begin{array}{l}\text { Program experiencing } \\
\text { increasing or decreasing } \\
\text { demand }\end{array}$ & $\begin{array}{l}\text { (56\%) Increasing some } \\
(42 \%) \text { Increasing } \\
\text { significantly }\end{array}$ & $\begin{array}{l}(30 \%) \text { Increasing some } \\
(50 \%) \text { Increasing } \\
\text { significantly }\end{array}$ \\
\hline Benefits & $\begin{array}{l}\text { (86\%) Improved business } \\
\text { relationships } \\
(83 \%) \text { Revenue for } \\
\text { program } \\
(69 \%) \text { Public relations for } \\
\text { CE program }\end{array}$ & $\begin{array}{l}\text { (87\%) Improved business } \\
\text { relationships } \\
\text { (66\%) Supports institutional } \\
\text { mission } \\
(63 \%) \text { Public relations for } \\
\text { CE } \\
(63 \%) \text { Revenue for program }\end{array}$ \\
\hline Barriers & $\begin{array}{l}\text { (42\%) Lack of qualified } \\
\text { instructors } \\
(42 \%) \text { Program } \\
\text { development }\end{array}$ & $\begin{array}{l}(40 \%) \text { Lack of internal } \\
\text { support } \\
(37 \%) \text { Market programs }\end{array}$ \\
\hline $\begin{array}{l}\text { Characteristics of successful } \\
\text { programs }\end{array}$ & $\begin{array}{l}(86 \%) \text { Talent } \\
(67 \%) \text { Curriculum } \\
\text { development } \\
(67 \%) \text { Delivery }\end{array}$ & $\begin{array}{l}\text { (73\%) Talent } \\
(73 \%) \text { Marketing } \\
(70 \%) \text { Curriculum } \\
\text { development }\end{array}$ \\
\hline
\end{tabular}

Universities with enrollments of 10,000-19,999 and 20,000 or more had contract training programs that were similar on many of the research questions including their 
reasons for offering contract training, how training is funded, types of programs offered, sectors seeking contracts, sectors with the most contracts, sectors producing the most revenue, benefits, and characteristics of successful programs. Both enrollment categories chose "component of continuing education mission" to be the top ranked reason for offering contract training. However, institutions with enrollments of 20,000 or more ranked institutional mission second (77\%). Institutions with enrollments of 10,000 19,999 reported revenue second $(80 \%)$ and institutional mission fourth (55\%), behind business demand (67\%). The relatively large percentage of private institutions in the $10,000$ enrolled category ( $38 \%)$ was one reason for this differential in purpose.

Institutions with larger enrollments relied more heavily on external resources to support their contract training programs. Institutions with enrollments of 20,000 or more supported their programs on "contracts only" 75 percent of the time, compared to 54 percent of the time for 10,000 enrolled institutions.

The revenue produced from contract training appeared to be similar. 10,00019,999 enrolled institutions reported revenue of $\$ 0-249,000(55 \%)$, compared to (60\%) for 20,000 or more enrolled institutions. Nineteen percent of institutions with enrollments of $10,000-19,999$ reported revenue of $\$ 250,000-499,999$, compared to none for 20,000 or more enrolled institutions. Both categories had six programs that produced \$1-million dollars or more in revenue.

Institutions with enrollments of 10,000-19,999 and 20,000 or more reported similar responses to sectors seeking services, sector that produced the most contracts, benefits and characteristics of success. Management and computer training ranked in the top three programs offered. The manufacturing sector produced the most contracts, most 
revenue, and sought out more contracts from continuing education units. Further, they both chose improved business relationships as the top benefit to conducting contract training and talent as the highest ranked characteristic of success.

Institutions with enrollment of 10,000-19,999 and 20,000 or more differed on only a few research questions. These included how training is funded, expected increases or decreases in revenue, barriers, and satisfaction levels with their contract training programs. Institutions with enrollments of 20,000 or more highest ranked category for contracts managed was $11-25$ contracts annually (37\%), compared to 10,000 enrolled institutions which ranked 1-10 contracts highest (44\%). This finding, combined with the revenue data, indicated that 20,000 or more enrolled institutions were producing less revenue per contract than institutions with enrollments of 10,000-19,999.

A very high percentage of institutions with enrollments of 10,000-19,999 and 20,000 or more expected to see increases in their contract training programs over the next five years. 20,000 or more enrolled institutions expected more "significant increases" (50\%) in revenue than 10,000-19,999 enrolled institutions (42\%). However, fewer 20,000 or more enrolled institutions were optimistic about growth (80\%), than institutions with enrollments of 10,000-19,999 (98\%).

The barriers mentioned most by institutions with enrollments of 10,000-19,999 included lack of qualified instructors (42\%) and program development (42\%). Institutions with enrollments of 20,000 or more identified lack of internal support (40\%) and market programs $(37 \%)$ as their top ranked barriers.

In all categories, institutions with enrollments of 10,000-19,999 enrolled institutions were more satisfied with their contract training programs than 20,000 enrolled 
institutions: financial (3.6 to 2.9 ), public relations ( 3.8 to 3.2 ), academic quality (4.3 to 3.9), and program development staff (3.6 to 3.4). The strong satisfaction rating from the financial indicator for institutions with enrollments of 10,000-19,999 may stem from the fact that they managed fewer contracts and produced similar financial returns as their larger counterparts. 20,000 or more enrolled institutions, however, were more mission driven than private institutions. The survey did not measure that particular satisfaction characteristic.

In summary, institutions with enrollments of 10,000-19,999 and 20,000 or more were more similar than different. The significant differences included institutions with enrollments of 20,000 or more relied more on "contracts only" to support their programs and managed more contracts for less revenue, than institutions with enrollments of $10,000-19,999$. Institutions with enrollments of 10,000-19,999 reported a greater overall level of satisfaction with their contract training program than institutions with enrollments of 20,000 or more.

Carnegie Classified Research and Doctoral-Granting Institutions: A Comparison of Contract Training Programs

The demographic and survey data for the comparison of research and doctoralgranting institutions are presented in Tables 24 and 25. Table 24 provides the demographic comparison of research and doctoral-granting institutions. 
Table 24

Demographic Comparison Contract Training Programs by Carnegie classification

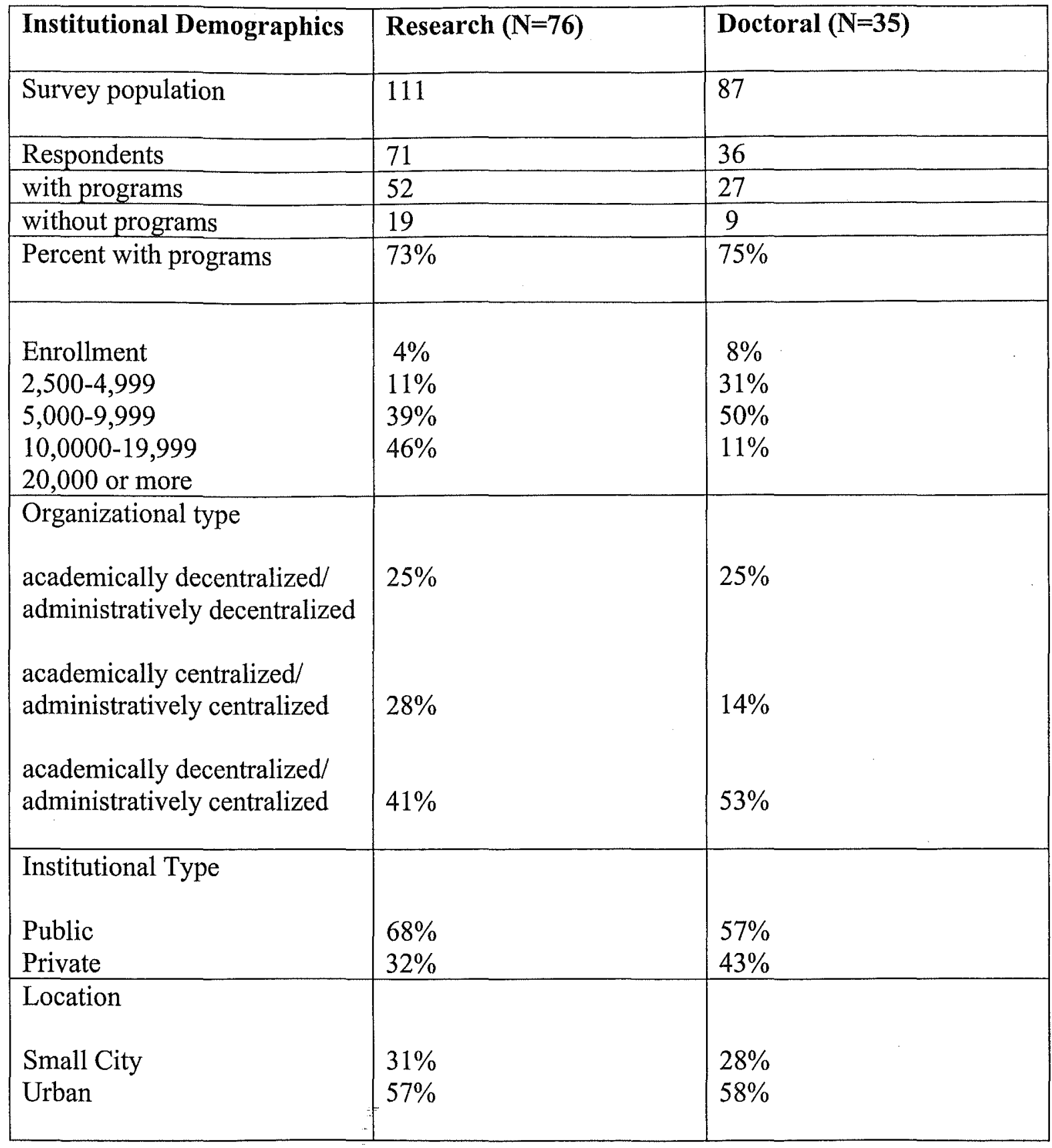

Research and doctoral institutions were similar on most demographics, except enrollment size. Research universities have larger enrollments, especially in the category of 20,000 or more $(46 \%$ to $11 \%)$. 
Although research and doctoral institutions supported contract training programs at a very similar rate $(73 \%$ to $75 \%)$, the overall response rate for each of these populations was significantly different. Doctoral universities responded to the survey at a 41 percent rate, compared to a 64 percent response rate by research institutions.

Table 25

Comparison of Contract Training Programs based on Carnegie classification

\begin{tabular}{|c|c|c|}
\hline Survey Responses & Research & Doctoral \\
\hline $\begin{array}{l}\text { Top reasons CE involved in } \\
\text { Contract training }\end{array}$ & $\begin{array}{l}(90 \%) \text { Component of CE } \\
\text { mission } \\
(85 \%) \text { Revenue for } \\
\text { institution } \\
(75 \%) \text { Business demand } \\
(65 \%) \text { Institutional mission }\end{array}$ & $\begin{array}{l}\text { (85\%) Component of CE } \\
\text { mission } \\
(63 \%) \text { Institutional mission } \\
(63 \%) \text { Revenue for } \\
\text { institution } \\
(59 \%) \text { Business demand }\end{array}$ \\
\hline How training is funded & $\begin{array}{l}(75 \%) \text { Training contracts } \\
\text { only }\end{array}$ & $\begin{array}{l}(48 \%) \text { Training contracts } \\
\text { only } \\
(26 \%) \text { Combination of } \\
\text { institutional budget and } \\
\text { contracts }\end{array}$ \\
\hline $\begin{array}{l}\text { University support for } \\
\text { program }\end{array}$ & $\begin{array}{l}\text { (40\%) Physical and capital } \\
\text { resources } \\
(37 \%) \text { Combination }\end{array}$ & $\begin{array}{l}\text { (48\%) Combination } \\
(33 \%) \text { Physical and capital } \\
\text { resources }\end{array}$ \\
\hline Average annual revenue & $\begin{array}{l}(54 \%) \$ 0-249,999 \\
(23 \%) \$ 1 \text { million- } 2.499 \\
\text { million }\end{array}$ & $\begin{array}{l}(70 \%) \$ 0-249,999 \\
(11 \%) \$ 250,000-499,999\end{array}$ \\
\hline Average number of contracts & $\begin{array}{l}\text { (33\%) } 1-10 \text { contracts } \\
(31 \%) 11-25 \text { contracts }\end{array}$ & (56\%) $1-10$ contracts \\
\hline Satisfaction level & & \\
\hline $\begin{array}{l}\text { Financial } \\
\text { Public relations } \\
\text { Academic quality } \\
\text { Program development staff }\end{array}$ & $\begin{array}{l}3.7 \\
3.8 \\
4.5 \\
3.8\end{array}$ & $\begin{array}{l}3.1 \\
3.4 \\
4.2 \\
3.4\end{array}$ \\
\hline
\end{tabular}


Table 25 (continued)

\begin{tabular}{|c|c|c|}
\hline Types of programs offered & $\begin{array}{l}\text { (94\%) Mgemt/supervision } \\
(71 \%) \text { Prof./tech } \\
(69 \%) \text { Computer }\end{array}$ & $\begin{array}{l}\text { (70\%) Mgemt/supervision } \\
(70 \%) \text { Computer } \\
(52 \%) \text { Communications }\end{array}$ \\
\hline Programs demanded & $\begin{array}{l}\text { (69\%) Mgemt/supervision } \\
(60 \%) \text { Communications }\end{array}$ & $\begin{array}{l}(56 \%) \text { Computer } \\
(52 \%) \mathrm{Mgemt} / \text { supervision }\end{array}$ \\
\hline Sectors seeking contracts & $\begin{array}{l}\text { (63\%) Manufacturing } \\
(44 \%) \text { Info. Tech } \\
(42 \%) \text { Finance }\end{array}$ & $\begin{array}{l}\text { (56\%) Health } \\
(44 \%) \text { Manufacturing }\end{array}$ \\
\hline Sector with most contracts & $\begin{array}{l}\text { (31\%) Info. Tech } \\
(29 \%) \text { Manufacturing }\end{array}$ & (41\%) Manufacturing \\
\hline $\begin{array}{l}\text { Sector producing most } \\
\text { revenue }\end{array}$ & $\begin{array}{l}(27 \%) \text { Info. Tech } \\
(21 \%) \text { Manufacturing }\end{array}$ & (33\%) Manufacturing \\
\hline $\begin{array}{l}\text { Program experiencing } \\
\text { increasing or decreasing } \\
\text { demand }\end{array}$ & $\begin{array}{l}(51 \%) \text { increasing some } \\
(41 \%) \text { increasing } \\
\text { significantly }\end{array}$ & $\begin{array}{l}\text { (44\%) increasing some } \\
(44 \%) \text { increasing } \\
\text { significantly }\end{array}$ \\
\hline Benefits & $\begin{array}{l}(90 \%) \text { Improved business } \\
\text { relationships } \\
(79 \%) \text { Revenue for } \\
\text { program } \\
(68 \%) \text { Fulfill CE mission }\end{array}$ & $\begin{array}{l}\text { (96\%) Improved business } \\
\text { relationships } \\
(78 \%) \text { Public Relations for } \\
\text { CE } \\
(78 \%) \text { Revenue for program }\end{array}$ \\
\hline Barriers & $\begin{array}{l}\text { (38\%) Program } \\
\text { development } \\
\text { (37\%) Marketing } \\
\text { (37\%) Time on other } \\
\text { programs }\end{array}$ & $\begin{array}{l}\text { (44\%) Lack of qualified } \\
\text { instructors } \\
(41 \%) \text { Program } \\
\text { development }\end{array}$ \\
\hline $\begin{array}{l}\text { Characteristics of successful } \\
\text { programs }\end{array}$ & $\begin{array}{l}(77 \%) \text { Talent } \\
(71 \%) \text { Curriculum } \\
\text { development } \\
(64 \%) \text { Delivery }\end{array}$ & $\begin{array}{l}\text { (85\%) Talent } \\
(70 \%) \text { Marketing } \\
\text { (63\%) Delivery }\end{array}$ \\
\hline
\end{tabular}

Research and doctoral university contract training programs resembled each other in a number of ways including reasons for offering contract training, university support of 
program, types of programs offered, expectations for future growth, benefits, and characteristics of successful programs. Both types of institutions chose "component of continuing education mission" to be the top ranked reason for offering contract training. However, doctoral institutions ranked institutional mission second, while research institutions ranked mission fourth behind revenue for institution and business demand. Management and computer training were ranked in the top three most prevalent types of programs offered. Both categories of institutions also had similarly optimistic views on the future of their contract training programs. Over 88 percent of the institutions expected their programs to grow in the next five years. Talent and delivery were considered two of the three most important characteristics of successful contract training programs.

Research and doctoral institutions differed on a number of research questions, including how training programs are funded, revenue and number of contracts, satisfaction ratings, sectors seeking contacts, sectors with most contracts, sectors that produce the most revenue, and barriers. Research institutions relied more heavily on training contracts "only" for funding than doctoral universities ( $75 \%$ to $48 \%)$.

Research institutions conducted larger contract training programs than doctoral institutions. Seventy percent of doctoral institutions produced revenue of less than $\$ 249,999$, compared to 54 percent of research institutions. Thirty-one percent of research institutions' contract training programs produced $\$ 1$-million or more in revenue. Only seven percent of doctoral programs produced $\$ 1$-million or more in revenue. The average number of contracts managed reflected a similar finding. A majority of doctoral institutions managed 1-10 contracts annually (56\%). This compared to public universities, which managed $1-10$ contracts (33\%), 11-25 contracts (31\%), and $26-50$ 
contracts (17\%). Research institutions also reported a higher level of satisfaction on all four measures: financial (3.7 to 3.1), public relations (3.8 to 3.4), academic program (4.5 to 4.2), and program development staff (3.8 to 3.4 ).

Programming and business sector interests were different for research and doctoral institutions. Management/supervision ranked at the top of both lists for programs offered, yet 94 percent of research universities offered management/supervision, compared to 70 percent at doctoral institutions. Research institutions then ranked professional/technical training second (71\%), while doctoral institutions ranked computers second (70\%) and communications third (52\%). Computer training was the program demanded most by businesses from doctoral institutions, and management/supervision was demanded most from research institutions.

The manufacturing sector sought the most contracts from research continuing education programs and the health sector sought the most from doctoral institutions. The information technology sector produced the most revenue and number of contracts for research institutions. The manufacturing sector produced the most contracts and most revenue for doctoral institutions.

Research and doctoral institutions reported that improved business relationships, revenue for the program, public relations for continuing education, and fulfillment of continuing education were important benefits. The only distinction lay in the small percentage differences.

Research and doctoral institutions ranked internal environmental barriers as most problematic to running a successful contract training program. Research universities identified program development, marketing, and time on other programs as the greatest 
barriers, while doctoral institutions reported lack of qualified instructors and program development as most problematic to their success.

In summary, research and doctoral continuing education units' contract training programs differed in a number of ways. Research institutions were more likely to have contract training programs that managed a greater number of contracts and produced more revenue annually than doctoral institutions. Research institutions were more likely to serve the information technology sector, while doctoral universities served the manufacturing sector. Research institutions found barriers in program development. Doctoral institutions reported lack of qualified instructors as the most problematic barrier.

Despite these differences, both types of institutions reported agreement on purpose for offering contract training, type of training program offered most, level of optimism toward future growth, benefits, and characteristics of success. The continuing education mission was the primary reason for offering contract training services to business and industry. Management/supervision and computer training were the programs most frequently offered. Research and doctoral institutions were very optimistic about the future growth. Improved business relationships was the greatest benefit, and talent and course delivery were most important to the success of contract training programs.

\section{A Comparison of Urban and Small City Contract Training Programs}

Urban and small city institution demographic and survey comparisons are presented in Table 26 and 27. 
Table 26

Demographic Comparison of Contract Training Programs by Location

\begin{tabular}{|l|l|l|}
\hline Institutional Demographics & Urban (N=66) & Small City (N=34) \\
\hline Respondents & 65 & 33 \\
\hline with programs & 51 & 22 \\
\hline without programs & 14 & 11 \\
\hline Percent with programs & $78 \%$ & $67 \%$ \\
\hline Enrollment & & \\
$2,500-4,999$ & $6 \%$ & $3 \%$ \\
$5,000-9,999$ & $22 \%$ & $12 \%$ \\
$10,0000-19,999$ & $43 \%$ & $42 \%$ \\
20,000 or more & $29 \%$ & $45 \%$ \\
\hline Organizational type & & \\
academically decentralized/ & $32 \%$ & $18 \%$ \\
administratively decentralized & & \\
academically centralized/ & & \\
administratively centralized & $28 \%$ & $18 \%$ \\
academically decentralized/ & & \\
administratively centralized & $34 \%$ & $58 \%$ \\
\hline Institutional Type & & \\
Public & $51 \%$ & \\
Private & $32 \%$ & \\
\hline Carnegie Classification & & \\
Research I and II & & \\
Doctoral I and II & & \\
\hline
\end{tabular}

Urban institutions were more likely to offer contract training services to the business community ( $78 \%$ to $67 \%$ ). The small city percentage participation rate was the lowest among all comparison groups. Urban and small city universities differed on a few 
demographics. Small city institutions were much more likely to be public universities ( $87 \%$ to $51 \%$ ), academically decentralized and administratively centralized (55\% to $34 \%$ ), and have enrollments of 20,000 or more ( $45 \%$ to $29 \%)$.

Table 27

Comparison of Contract Training Programs by Location

\begin{tabular}{|c|c|c|}
\hline Survey Responses & Urban & Small City \\
\hline $\begin{array}{l}\text { Top reasons CE involved in } \\
\text { Contract training }\end{array}$ & $\begin{array}{l}(82 \%) \text { Component of CE } \\
\text { mission } \\
(78 \%) \text { Revenue for } \\
\text { institution } \\
(63 \%) \text { Business demand }\end{array}$ & $\begin{array}{l}(86 \%) \text { Component of } \mathrm{CE} \\
\text { mission } \\
(82 \%) \text { Business demand } \\
(73 \%) \text { Institutional mission } \\
(59 \%) \text { Revenue for } \\
\text { institution }\end{array}$ \\
\hline How training is funded & $\begin{array}{l}(65 \%) \text { Training contracts } \\
\text { only }\end{array}$ & $\begin{array}{l}\text { (64\%) Training contracts } \\
\text { only } \\
(32 \%) \text { Combination of } \\
\text { institutional budget and } \\
\text { contracts }\end{array}$ \\
\hline $\begin{array}{l}\text { University support for } \\
\text { program }\end{array}$ & $\begin{array}{l}\text { (39\%) Physical and capital } \\
\text { resources } \\
(33 \%) \text { Combination }\end{array}$ & $\begin{array}{l}(45 \%) \text { Combination } \\
(32 \%) \text { Physical and capital } \\
\text { resources }\end{array}$ \\
\hline Average annual revenue & $\begin{array}{l}(47 \%) \$ 0-249,999 \\
(20 \%) \$ 1 \text { million-2.49 } \\
\text { million } \\
(10 \%) \$ 2.5-4.99 \text { million }\end{array}$ & $\begin{array}{l}(73 \%) \$ 0-249,999 \\
(18 \%) \$ 1-2.49 \text { million }\end{array}$ \\
\hline Average number of contracts & $\begin{array}{l}(41 \%) 1-10 \text { contracts } \\
(16 \%) 11-25 \text { contracts } \\
(18 \%) 51-100 \text { contracts }\end{array}$ & $\begin{array}{l}(27 \%) 1-10 \text { contracts } \\
(41 \%) 11-25 \text { contracts }\end{array}$ \\
\hline \multicolumn{3}{|l|}{ Satisfaction level } \\
\hline $\begin{array}{l}\text { Financial } \\
\text { Public relations } \\
\text { Academic quality } \\
\text { Program development staff }\end{array}$ & $\begin{array}{l}3.3 \\
3.4 \\
4.2 \\
3.5\end{array}$ & $\begin{array}{l}3.4 \\
3.5 \\
3.9 \\
3.5\end{array}$ \\
\hline Types of programs offered & $\begin{array}{l}(75 \%) \text { Mgemt/supervision } \\
(68 \%) \text { Computer } \\
(57 \%) \text { Communications }\end{array}$ & $\begin{array}{l}\text { (91\%) Mgemt/supervision } \\
(59 \%) \text { Prof/tech } \\
(55 \%) \text { Computer }\end{array}$ \\
\hline
\end{tabular}


Table 27 (continued)

\begin{tabular}{|c|c|c|}
\hline Programs demanded & $\begin{array}{l}(59 \%) \text { Computer } \\
(51 \%) \text { Mgemt/supervision }\end{array}$ & $(82 \%) \mathrm{Mgemt} /$ supervision \\
\hline Sectors seeking contracts & $\begin{array}{l}\text { (49\%) Manufacturing } \\
(47 \%) \text { Info. Tech } \\
(39 \%) \text { Health }\end{array}$ & $\begin{array}{l}\text { (73\%) Manufacturing } \\
(50 \%) \text { Health } \\
(41 \%) \text { Finance }\end{array}$ \\
\hline Sector with most contracts & $\begin{array}{l}\text { (31\%) Manufacturing } \\
(29 \%) \text { Info. Tech }\end{array}$ & (36\%) Manufacturing \\
\hline $\begin{array}{l}\text { Sector producing most } \\
\text { revenue }\end{array}$ & $\begin{array}{l}(27 \%) \text { Info. Tech } \\
(25 \%) \text { Manufacturing }\end{array}$ & (27\%) Manufacturing \\
\hline $\begin{array}{l}\text { Program experiencing } \\
\text { increasing or decreasing } \\
\text { demand }\end{array}$ & $\begin{array}{l}(49 \%) \text { increasing some } \\
(45 \%) \text { increasing } \\
\text { significantly }\end{array}$ & $\begin{array}{l}(41 \%) \text { increasing some } \\
(50 \%) \text { increasing } \\
\text { significantly }\end{array}$ \\
\hline Benefits & $\begin{array}{l}\text { (82\%) Improved business } \\
\text { relationships } \\
(78 \%) \text { Revenue for } \\
\text { program } \\
(59 \%) \text { Public relations for } \\
\text { CE program }\end{array}$ & $\begin{array}{l}\text { (91\%) Improved business } \\
\text { relationships } \\
(82 \%) \text { Public Relations for } \\
\text { CE } \\
(68 \%) \text { Revenue for program }\end{array}$ \\
\hline Barriers & $\begin{array}{l}\text { (41\%) Program } \\
\text { development } \\
(37 \%) \text { Lack of qualified } \\
\text { instructors }\end{array}$ & $\begin{array}{l}\text { (36\%) Lack of internal } \\
\text { support } \\
(36 \%) \text { Program } \\
\text { development }\end{array}$ \\
\hline $\begin{array}{l}\text { Characteristics of successful } \\
\text { programs }\end{array}$ & $\begin{array}{l}(80 \%) \text { Talent } \\
(67 \%) \text { Curriculum } \\
\text { development } \\
(67 \%) \text { Delivery }\end{array}$ & $\begin{array}{l}(86 \%) \text { Talent } \\
(73 \%) \text { Marketing } \\
(68 \%) \text { Curriculum } \\
\text { development }\end{array}$ \\
\hline
\end{tabular}

Urban and small city university contract training programs resembled each other in a number of ways, including reasons for offering contract training, how training is funded, university support of program, types of programs offered, sectors seeking 
contracts, sectors with the most contracts, satisfaction ratings, expectations for future growth, benefits, barriers, and characteristics of successful programs. Urban and small city institutions chose "component of continuing education mission" and "business demand" as one of their top three reasons for supporting contract training. Urban universities ranked revenue second (78\%) and fulfillment of institutional mission fourth (55\%). Conversely, small city universities ranked revenue fourth (59\%) and fulfillment of institutional mission third (73\%). Management and computer training were ranked as the top three most prevalent types of programs offered. Small city institutions offered professional/technical training more often than urban institutions (59\% to 51\%), while urban institutions offered communications training more often than small city institutions $(57 \%$ to $50 \%)$. The manufacturing sector sought the most contracts and had the most contracts with both small city and urban institutions. Over 90 percent of the universities expected their programs to grow in the next five years.

Institutions located in small city and urban areas reported similar satisfaction ratings. Rankings of financial (3.3 to 3.4), public relations (3.4 to 3.5), and program development staff (3.5 to 3.5) were almost identical. Urban institutions were slightly more satisfied with the academic quality of their programs than small city (4.2 to 3.9) institutions.

Urban and small city universities also concurred that improved business relationship, revenue for continuing education program, and public relations for continuing education program were the top benefits of conducting contract training programs. Program development ranked as the top barrier, and talent and curriculum 
development were rated as two of the three most important characteristics of successful contract training programs.

Urban and small city institutions differed on a few research questions. The areas of contrasting results included the percentage of survey respondents supporting average dollar size of programs, average number of contracts, and sectors producing the most revenue. Urban universities reported a higher revenue stream from their contract training programs. Thirty percent of these programs reported revenue exceeding \$1-million, while only 18 percent of small city programs had that level of revenue. The $\$ 0-249,999$ revenue category received over 73 percent of the small city responses, compared to 47 percent for urban programs. Seventy-three percent of small city programs managed 11-25 contracts or more annually. This compared to urban programs that managed 11-25 contracts 59 percent of the time. Urban institutions managed 1-10 contracts at almost twice the rate of small city universities ( $41 \%$ to $27 \%$ ). However, 29 percent of urban university continuing education programs were managing 51 or more contracts annually.

Urban institutions received the most revenue from the information technology sector. Small city universities were most likely to have their largest revenue contract from the manufacturing sector.

In summary, urban and small city continuing education units' contract training programs were more similar than different. Management and supervisory training offered to the manufacturing and information technology sectors were common for both types of institutions. They were optimistic about the future and had similar results on satisfaction ratings, benefits, barriers, and characteristics of successful programs. 
Urban institutions, however, managed more contracts and produced more revenue than small city contract training programs.

\section{Summary of Findings}

This chapter summarized and analyzed the data collected for the study using narrative and tables to describe the findings. The research questions and profile comparisons provided two different perspectives of the data. The significant findings from the analysis of the research questions and profiles were summarized in this section.

Universities of all sizes, types, and classifications conducted contract training with business and industry in 1998. Seventy-five percent of the respondents reported providing contract training services to business and industry.

Continuing education units conducted contract training with business and industry primarily to fulfill its mission, produce needed revenue, and meet demand from the business community. Contract training was funded mostly by revenue generated from training contracts. Most institutions dedicated three or fewer full-time staff to their contract training programs. These staff members managed as few as 1-10 contracts and as many as 100 , but most averaged $11-25$ contracts annually.

Revenue from contract training programs ranged from \$0-249,999 to \$5-million. Nearly 60 percent of the contract training programs produced annual revenue of less than $\$ 249,999$. Contract training annual enrollments ranged from fewer than 99 to 5,000 students per year. Over 50 percent of the programs provided training to 500 or fewer participants each year. A large majority of contract training programs also served businesses within a 100-mile radius of campus. 
Seventy-five percent of institutions experienced some increase in their contract training programs in the last five-year period (1993-1998). Ninety-three percent of the respondents expected their contract training programs to grow over the next five years.

Overall, continuing education units reported ratings of satisfied or better with their contract training programs. Continuing education units were most satisfied with the academic quality, public relations, program staff, and least satisfied with their financial return.

The manufacturing, health services, information technology, and finance sectors were most likely to seek university continuing education units' contract training services. Manufacturing and information technology sectors entered the greatest number of contracts and provided the largest revenue producing contracts to continuing education units. Seventy-one percent of the companies served by continuing education contract services had employee bases of 100 or more.

The most prevalent training programs offered were management/supervision, computer programming, communications, and professional/technical. The same set of courses was the most demanded training by business and industry, although to a lesser percentage than offered. Middle managers and professional/technical workers received over 80 percent of the training provided by continuing education.

Continuing education units derived many benefits from their contract training programs. The most highly ranked benefits were improved relationship with the business community, revenue for the institution, positive public relations, and fulfillment of mission. The barriers chosen most frequently were time to develop programs, lack of qualified instructors, inability to market programs, time constraints of other programs, 
and lack of internal support. The most highly ranked characteristics of successful programs included talented personnel, curriculum development, delivery, and marketing. Profile comparisons of public and private institutions, institutions with enrollments of 10,000-19,999 and 20,000 or more, research and doctoral-granting institutions, and small city and urban institutions were conducted to provide a more comprehensive examination of the data. These profile comparisons examined a number of research questions in an attempt to identify trends and activity levels of these various groups.

Despite their demographic and organizational differences, these eight separate populations of respondents were similar to the aggregated data in a number of ways. They supported contract training at similar levels, ranging from 67 percent to 77 percent. Their top reason for providing contract training was to support their continuing education mission. Management and supervision was the program most offered. The manufacturing and information technology sectors were the primary clients for contracts. Most expected their programs to experience increased revenue in the years ahead. Improving business relationships was the greatest benefit, and talent was the most important characteristic to success.

The comparison groups of institutions with enrollments of 10,000-19,999 and 20,000 or more and urban and small city institutions had the most similarities. The distinguishing characteristics for the enrollment groups were institutions with enrollments of 20,000 or more relied on "contracts only" to support their programs and managed more contracts for less revenue, than institutions with enrollments of 10,000-19,999. 
Institutions with enrollments of 10,000-19,999 reported a greater satisfaction level with their contract training program.

Urban and small city continuing education units' contract training programs were also more similar than different. The questions where urban and small city institutions differed most were in revenue production and percent of institutions supporting contract training. Urban institutions supported contract training programs 11 percent more often than small city institutions. Urban institutions were also more likely to produce revenue of over \$1-million annually.

The populations demonstrating the greatest differences were the groupings of public and private institutions and research and doctoral institutions. Public institutions managed a greater number of contracts and produced more revenue annually than private institutions. Private institutions were more revenue driven than their public counterparts, which ranked serving their institutional mission more highly. Private institutions found barriers in demands from other programs and finding qualified instructors, but were more optimistic about the future growth of their contract training programs than public institutions. Public institutions found improved business relationships to be the greatest benefit, and program development, marketing and internal support to be the greatest barriers to success. Private institutions found revenue the greatest benefit and demands of other programs and lack of qualified instructors as the most significant barriers.

Research and doctoral continuing education units' contract training programs also differed in a number of ways. Research institutions were more likely to conduct contract training programs that managed a greater number of contracts and produced more revenue annually than doctoral institutions. Research institutions were more likely to 
serve the information technology sector, while doctoral universities served the manufacturing sector. Research institutions reported a higher level of satisfaction than doctoral-granting institutions. Research institutions found barriers in program development. Doctoral institutions reported lack of qualified instructors as the most problematic barrier.

Based on the findings, public, research institutions located in urban settings with enrollments of 20,000 or more were most likely to rely on "contracts only" for program support, have contract training programs that generated the greatest number of contracts and produced the highest level of revenue. Private, doctoral institutions located in small cities with enrollments of 10,000-19,999 were more likely to manage fewer contracts and produce less revenue from their contract training programs. 


\section{CHAPTER 5}

\section{DISCUSSION AND RECOMMENDATIONS}

\section{Introduction}

This chapter includes a discussion of the findings and recommendations for future research. Research findings found in Chapter IV will be synthesized with the literature to present the conclusions regarding the role of university continuing education units in contract training for business and industry. The last section of the chapter provides recommendations for future research on higher education's role in training and development for business and industry.

The primary focus of this study was to explore the role of university continuing education units in training and development for business and industry. Seventeen research questions were examined in the study related to what kind, to whom, and how often universities were providing corporate training services. The perceived benefits and barriers of offering contract training programs to business and industry were also examined.

The data were collected through the use of a survey instrument developed by the researcher and sent to 195 doctoral-granting institutions across the country. One hundred and eleven usable surveys were returned, yielding a return rate of 56 percent. Forty-two states were represented in the study. 


\section{Discussion}

The findings from the seventeen research questions are discussed in this section. Research conclusions based on the analysis and results presented in Chapter IV for the seventeen research questions will also be presented. This research project presented several additional research possibilities for exploring the role of universities in contract training for business and industry. The chapter will conclude with a discussion of these opportunities.

Research Question 1: Are corporate workforce development activities an accepted part of the continuing education units' mission?

The reported 75 percent participation rate indicated that most university continuing education units view corporate contract training as part of their mission to serve the community and marketplace (Shoemaker, 1998). This finding closely mirrors the participation rate of community colleges (Carnevale, et al., 1990).

The finding that public institutions participated more frequently than private institutions ( $80 \%$ to $66 \%)$ in contract training was not unexpected. The receipt of public funds and a commitment to service in their missions suggested that public universities would participate at a higher level.

An urban location of an institution also increased the likelihood of sponsoring contract training, compared to a small city institutional location (78\% to $67 \%)$. The economic opportunity, access to an educated labor force, and breadth and size of the business community appear to make an urban location a better market place for training and development services than a small city. 
Although enrollment size influenced several other characteristics of an institution's contract training program, such as number of contracts, revenue, and staffing, institutional enrollment size did not affect participation rates. Institutions with enrollments of 10,000-19,999 participated at the same rate as institutions with enrollments of 20,000 or more (77\%). Doctoral and research institutions also participated in contract training at a similar rate $(73 \%$ to $75 \%)$.

Interestingly, private institutions, which were located primarily in urban settings (84\%), had the lowest overall participation rate $(66 \%)$. This finding suggested that institutional type was a more influential characteristic than location, Carnegie classification, and enrollment size, in whether an institution participates in contract training for business and industry.

The reported reasons university continuing education units participate in contract training were: It is a component of the continuing education mission, a revenue producer, demanded by the business community, and part of the institutional mission. These were similar to findings by Powers, et al. (1988). The high ranking of "produces revenue" and "demand from business community" provided evidence that the higher education community receives internal and external pressure to provide contract training services.

Based on the literature, certain outcomes would be expected from the study, including the findings that private universities were more revenue focused than institutional mission focused ( $80 \%$ to $40 \%$ ); that public institutions received more pressure from the business community to offer training services ( $71 \%$ to $56 \%)$; and that small city institutions would feel more pressure from the business community to provide 
training services ( $82 \%$ to $63 \%$ ). All three suppositions were supported by the data collected in this study.

Research Question 2: What financial support does the university provide for corporate workforce development programs (i.e., are corporate workforce development programs expected to be self-sufficient)?

Most continuing education units reported supporting their corporate training programs with "revenue only." An additional 20 percent reported receiving some combination of physical space, equipment, and access to administrative services from their universities. Public research universities with enrollments of 20,000 or more were more likely to be funded through corporate training contracts "only" than other types and sizes of institutions.

Continuing education units that function mostly as an auxiliary enterprise at their institution receive only modest budgetary support. Continuing education programming, therefore, must be self-sufficient (i.e., produce revenue equal to or greater than the program cost). Most corporate contract training programs were meeting this benchmark and producing additional revenue for the institution.

Research Question 3: How many staff members are dedicated to corporate contract training activities?

The demands of administering contract training programs were significant enough to warrant full time dedicated staff. In over 50 percent of the cases, two or more staff positions were devoted exclusively to corporate contract training programs. The level of staff resources committed to contract training indicated how important and valued this type of programming was to continuing education unit. 
Research Questions 4, 5, and 6: How many total corporate contract training programs are offered each year by continuing education units: What was the 1998 enrollment in continuing education sponsored contact training: And, are continuing education units' corporate training programs serving local, regional, national, and international interests?

The findings provided evidence that many universities have made a commitment to providing training and development services. Continuing education units' contract training programs were serving an average of 11-25 companies and training between 100499 employees annually. Public universities with enrollments of 20,000 or more were more likely to serve a higher number of contracts and more employees. Small city and research institutions also were more likely to manage a greater number of contracts than others types of universities.

The data from this study indicated that 81 percent of contracts were developed and conducted within a 100-mile radius of campus. This finding was consistent with Charner and Rolzinski (1987) study, which reported that geographic proximity gives both parties a better understanding of each other's purpose and mission and was the most common reason for establishing partnerships.

Research Question 7: How much revenue is produced by corporate contract training programs?

Clearly, public research universities with enrollments of 20,000 or more were generating more overall revenue than the other types and sizes of institution. An urban setting was also more likely to produce higher overall revenue.

Capturing the total revenue produced by contract training programs was difficult from the data provided. The most commonly chosen response was $\$ 0-249,999$. This presents some challenges because there is no base line dollar figure. Since revenue could be between $\$ 0$ and $\$ 249,999$, trying to determine aggregate revenue production by 
continuing education units was difficult. One method of projecting aggregate revenue from the data collected in this study was by using the median for each category of revenue produced. The exception was the $\$ 5$-million category, which was coded as $\$ 5$ million in the formula. By multiplying that number by the number of respondents, an aggregate revenue figure for each category was reached. The categories were then added together, giving an estimated revenue figure for continuing education's contract training programs.

For this sample, the mid-point of $\$ 125,000$ was used for the $\$ 0-249,999$ category; this was multiplied by the 49 respondents. This produced a total estimated revenue value of $\$ 6.125$ million. The remaining categories produced estimated revenue of $\$ 3.2$ million, $\$ 4.5$ million, $\$ 24.5$ million, $\$ 20$ million and $\$ 5$ million, respectively. The total estimated revenue for the population of respondents was $\$ 63.3$ million.

In an industry that reported spending $\$ 16$ billion annually on formal training (Frazis, et, al., 1998), university continuing education units appear not to be significant overall providers of contract training. However, based on the data collected in this study, it does appear that university continuing education units' contributions were important to their local and regional business communities. Continuing education units' contributions combined with the contributions of other possible institutional providers of training, such as schools or departments of business, engineering, health science, computer science, environmental science, and public administration, suggest that higher education can be a valuable and active provider of training and development services to business and industry.

Research Question 8: Are continuing education units increasing or decreasing their involvement in contract training? 
Ninety-three percent expected revenue to increase in the next five years. Seventyfive percent of continuing education units reported producing significantly more revenue from 1993 to 1998. This finding supported the study's premise that technology, globalization, demographic shifts, and workplace changes were increasing demand for training and development. The data also supported Shoemaker's (1998) prediction that continuing education would provide increasingly more training services to business and industry.

Some differences in future expectations existed between types and size of universities, however. Small city and urban institutions were equally optimistic, but private institution respondents located in urban settings were less optimistic. Perhaps, this was because they were more inclined to serve information technology clients and less likely to have a knowledge advantage over other types of training vendors on this subject matter. In addition, the fact that urban institutions with enrollments of 10,000-19,999 found a barrier in finding instructors may have also moderated expectations. Overall, a majority of continuing education units view contract training as an expanding and productive enterprise for their operations.

Research Question 9: Are continuing education units satisfied with their corporate contract training programs?

The overall positive satisfaction measures of quality, staff, public relations, and financial, combined with the high level of optimism regarding future growth of these programs, indicated that continuing education units and the business community have embraced corporate contract training as an attractive forum for partnerships. Gerlach's 
(1992) finding that partnerships were beneficial to both parties appears to be supported by this study.

Providing quality educational services undergirds the mission of higher education, so one would have expected to find academic quality and staff as highly ranked satisfaction measures. The positive rating of public relations provided evidence that continuing education units were receiving positive external and internal feed back regarding their involvement in contract training. The lowest rated satisfaction measure, financial, suggested some discomfort with the business approach of producing on-time, real-time training at a reasonable cost. The lower ranking of financial appeared not to indicate any overall displeasure with contract training programs, but this may be a satisfaction measure that is never rated extremely high.

Fairweather (1988) suggested that higher education's organizational structure may limit entrepreneurial approaches required for developing successful business partnerships. The indication from this study, however, was that most continuing education units were more than "satisfied" on all measures.

Research Questions 10 and 11: What types of corporate training programs (management, professional/technical, basic, etc.) do continuing education units offer: And, what type of training program is most commonly requested by business and industry?

Similar to the U.S. Department of Labor, Bureau of Labor Statistics findings (1996), the most commonly delivered training programs were management/supervision, computer programming, professional/technical, and communications. The comparisons based on institutional type, size, location, and Carnegie classification produced no significant differences in type of program delivered. 
The most requested training programs by business and industry were the same as those delivered, except communications was demanded more often than professional/technical training. The percentage difference between most delivered by continuing education units and most requested by business, however, were significant. For example, management/supervision was delivered by 83 percent of continuing education units, while the respondents reported that business demanded management/supervision training only 60 percent of the time. A 20- to 25-percentage differential existed for top ranked programs between programs delivered and programs demanded. This differential may reflect the continuity of program offered by continuing education units and the breadth of demands for training by business and industry. It might also suggest a possible disconnect between what the market was demanding and what continuing education units were capable of providing.

The finding that 33 percent of continuing education units provided basic training to business and industry appeared inconsistent on two accounts. First, the Bureau of Labor Statistics study (BLS, 1996 July 10) found that most training dollars were spent on educated, professional, male Caucasians. Second, continuing education units provided no particular knowledge or price advantage over other vendors when it comes to delivering basic skills training. One explanation for this inconsistency might be found in the fact that the manufacturing sector was the highest ranked sector served by continuing education units. In an industry that has historically relied more on brawn then brains, more basic skill training may be necessary than for other sectors. By providing a baseline of basic skills, continuing education units were positioned to offer more advanced computer and technology based training programs. 
Research Question 12: What level of employee do continuing education units' contract training programs most often serve?

As previous studies have shown (BLS, 1996 July 10), most training goes to collegeeducated professionals. This study found that 82 percent of respondents reported training primarily middle managers and professional/technical workers. The data were similar for all types, sizes, classifications, and location of institutions. The findings from other research questions related to types of training delivered and demanded also supported this result.

Research Question 13: What size companies are seeking corporate training services?

Over 90 percent of the businesses served by continuing education units were over 100 employees; better than 50 percent of continuing education clients were firms with over 500 employees. These findings were consistent with the BLS study survey that found companies with 100 or more employees received most of the formal training (BLS, 1996 July 10). Continuing education units' programs were concentrated on the training market that demands and offers the most training and development services to their employees. Interestingly, companies of less than 100 employees, which were reportedly the fastest growing segment of all companies (Zemsky and Oedel, 1994) and which will need training services, was a market mostly ignored by continuing education units. Just 15 percent reported serving this size company.

Research Question 14: What sectors of businesses (i.e., insurance, finance, and technology) are seeking training services from continuing education?

The findings indicated that university continuing education units were serving a broad and diverse set of business sectors. The most common sectors served by continuing education units were manufacturing, health services, information technology, 
and finance. These sectors, except manufacturing, would appear to support the characteristics (i.e., proportionately high numbers of educated, professional staff) of sectors likely to offer formal training opportunities. The three sectors were also service oriented and important contributors to the new information economy.

The manufacturing and information technology sectors produced the largest number of contracts and the most revenue for continuing education units. Despite a second ranking among sectors served, health services ranked fourth in number of contracts and revenue produced. Continuing education units may not be able to serve all the needs of an industry with such a diverse and specialized workforce. The health services sector might also be receiving training services from other campus academic units such as from academic medical centers.

The economic transformation from an industrial to an information economy would appear to suggest that manufacturing's interest in supporting training and development would be low, and higher education's involvement unlikely. One explanation for the actual finding is global competition. As the manufacturing sectors works to become more efficient and productive, the demand for more advanced technology and new management practices grows exponentially. This is a phenomenon similar to the one experienced by the farming sector at the turn of the last century, when it consolidated, increased its use of technology, and adopted new management practices.

The manufacturing sector sought out proportionately more contracts from institutions located in small city settings. University continuing education units in this setting give firms access to innovative knowledge and training that they were unlikely to find with other types of training providers. 
Tumultuous change and the move toward managed care have required the health care sector also to focus on new technology and new management practices. Continuing education units, especially in small cities, provided the health care sector with access to expertise in academic medical centers, nursing programs, and public administration programs.

This study's findings, however, do not match the EQW survey, which found that utilities, finance, insurance, and communication companies were most likely to offer formal training (Lynch and Black, 1996). Utilities and insurance companies were ranked in the top eight sectors served by continuing education units, while the communications sector was near the bottom. The limited scope of this study makes it difficult to hypothesize why this inconsistency exists; nonetheless, the findings could provide continuing education units with a better understanding of the sectors that welcome and use their services. Interestingly, in this new information economy, the service sector ranked in the middle of sectors served. Two characteristics of this sector, high turnover and low skill requirements, might explain why the service sector was ranked less highly in sectors served (Lynch and Black, 1996).

Research Question 15: What university benefits are derived from offering training programs to business and industry?

University continuing education units reported improved business relationships and increased revenue, beneficial public relations, fulfillment of their mission, increased enrollment in other programs, and opportunity to provide real world contact to faculty. These benefits resembled those received by community colleges (Powers, et al.1988). The only dissimilar benefit was increased enrollment to other continuing education programs. The breadth of programs offered by a university continuing education program 
as compared to a community college program may explain why contract training programs were more likely to experience increased enrollments for other continuing education programs.

Research Question 16: What problems and barriers limit universities from providing corporate training programs?

Continuing education units found a number of barriers to delivering corporate training, including lack of time to develop training programs, lack of qualified instructors, inability to properly market programs, time constraints of their other programs, lack of internal support, and the fact that continuing education was not seen as a provider of contract training. Five out of six of the barriers were time and labor issues rather than external environmental factors, such as attitude of corporate executives and university leadership.

The data suggested that continuing education units view most of the barriers to offering contract training as mostly internally focused. With more time, staff, and marketing talent, most of the significant barriers could be managed. The perceived pressure on time and staff suggested, too, that the demand for corporate training was greater than the services university continuing education units can currently provide. The reported finding that businesses do not see continuing education units as a training provider indicated that this kind of study, combined with better marketing and public relations, are necessary to dispel this notion.

Aslanian (1988) found differences in attitude, administrative philosophies, and contrasting professional work styles limited business/higher education partnerships. The data from this study showed that few senior executives or academic leaders were barriers, and even fewer reported that state or local agencies were barriers to forming training 
partnerships. This finding suggested that both higher education and the business community were finding ways to overcome these obstacles.

Institutional size and institutional organizational structure influenced the ranking of barriers. Smaller institutional size ranked "lack of qualified instructors" as the most significant barrier, while institutions with enrollments of 20,000 or more ranked "lack of internal support" highest. One explanation is that one third of 20,000 or more institutions reported being centralized academically and administratively. This is a type of organizational structure that increases the likelihood that bureaucratic academic procedures and resource allocation processes will make adapting to external market forces difficult. Paradoxically, these institutions were among the most active participants in contract training.

Research Question 17: What characteristics facilitate effective corporate contract training programs between business and higher education?

This study supported Ballantyne's (1985) findings that talented personnel, curriculum development, delivery, and marketing were the most important characteristics of a successful program. These findings were also consistent with the findings in the previous research question that many of the barriers were linked to personnel.

Several other characteristics of success received significant notice, including defined processes, systems and procedures, previous business relationships with business community, and evaluation and follow-up procedures. These characteristics complemented the more highly ranked items, and together provided most of the elements for a successful program. Having talented personnel who develop and deliver training programs that businesses want in a format that works, while also having the infrastructure 
to support and process people through the program, is likely to produce good results for both the provider and the business receiving the services.

Despite identifying time constraints and lack of internal support as significant barriers, only 37 percent of respondents identified internal commitment of financial resources as a necessary characteristic of success. This barrier was ranked ninth out of twelve potential responses. According to the pilot study participants, contract training programs were added to the continuing education unit programming base with the understanding that these programs would be self-sufficient. An institutional investment of resources was probably never part of the internal agreement, so few expect additional resources from their university.

Continuing education units, however, appear to have attracted more corporate interest in their training contracts than they can support. Their responses regarding barriers to success suggest a need for an infusion of staff and resources to meet the growing demand. Unlike a for-profit enterprise that examines opportunity based on the bottom line and market potential, higher education leadership will likely view any additional investment in terms of overall mission and whether expanding the program has institutional value. This demonstrates the differences in the two cultures, and suggests the balancing act continuing education units must perform to serve both interests.

The reported findings that senior management and government officials have little influence on the success of contract training programs suggested that continuing education units and business leaders were functioning autonomously in the development and implementation of these programs. One would have expected federal, state, and local governments to be monitoring the involvement of higher education in economic 
development and workforce training, but there was little indication that that was occurring.

\section{Conclusions}

Based on the review of the literature and an analysis of the data collected from the research surveys several conclusions were reached.

1. All sizes and types of colleges and universities were participating in contract training. Institutional enrollment (size) and location affect participation rates, however. Public, research institutions, with enrollments of 20,000 or more, located in urban centers, were most likely to offer contract training to business and industry. Private institutions, with enrollments of 10,000 or less, located in small cities, were least likely to participate in contract training.

2. In the current political and economic environment, where higher education is being criticized for not participating on a higher level in real world issues such as economic development, the high level of participation by university continuing education units in contract training should help improve this perception. This should be especially beneficial to public institutions, as they face increasing pressure from state governments to increase their involvement in economic development. Despite some question by those in higher education regarding the value of being involved in economic development activities such as corporate contract training, the findings indicated that many continuing education leaders and institutions have embraced training as a vital part of their mission. Continuing education must manage expectations from both sides, however. These programs need to fulfill institutional 
expectations to serve the local and regional economy, while also providing individualized training programs to the business community.

3. Continuing education units view their participation as part of their continuing education mission of serving the community and market place. The opportunity to produce revenue was also seen as an important reason for providing contract training, especially for private universities. Most programs reported being self-sufficient, receiving little funding from their institution.

4. Most continuing education units dedicated two or more full time staff to their contract training programs. On average, these staff members managed between 11-25 contracts and served 100-500 employees annually. Revenue produced from these programs was mostly in the $\$ 0-249,000$ category; however, more than a quarter of participants reported revenue of 1-million dollars or more.

5. Nearly all continuing education units expected their programs to grow over the next five years. Programs were satisfied with the academic quality, their staffing, the public relations received, and the financial rewards of offering contract training.

6. The manufacturing sector was university continuing education's best customer, followed by the health care, information technology, and finance sectors, respectively. The transformation required of manufacturing to compete in the global economy and higher education's information and knowledge advantage were two reasons why manufacturing may have chosen university continuing education as one of their training providers.

7. Continuing education units were serving companies of 100 or more employees. Only 15 percent of continuing education units reported serving companies with less than 
100 employees. Nearly all contract training programs were offered within a 100-mile radius of campus.

8. Similar to the findings in previous studies, management/supervision, computer programming, professional/technical, and communication were the most common programs delivered by continuing education units. They were also the courses most desired by business and industry. Middle managers and professional/technical workers received most of this training.

9. The benefits received from offering contract training closely mirrored those found in earlier studies. The exception to this was increased enrollment for other programs. The expansive program offerings of continuing education, compared to community college programs, might explain the high ranking of this new benefit. Improved business relations, increased revenue, and better public relations for continuing education were clearly seen as positive incentives for conducting contract training programs.

10. Most of the barriers were internal ones, related to the need for more talented staff to instruct classes, design courses, and market programs. The concerns expressed in the literature concerning the different work styles, administrative philosophies, and attitudes between business and higher education were not strongly expressed by the respondents. There was some indication that continuing education was straddling the two cultures of academia and business to successfully manage their contract training programs. The characteristics of successful contract training programs were perceived to start with having talented personnel to develop curricula, deliver courses, and market programs. 
11. Contract training programs produce revenue, increase enrollment in other programs, enhance internal and external visibility, and improve relationships with the business community. This type of programming has brought important visibility, credibility, and resources to university continuing education units as well as to their universities.

\section{Recommendations for Future Research}

This study presented a number of possibilities for future research. Suggestions include to: replicate this study over the full range of continuing education offerings across an entire campus; conduct a comparative study of large and small programs; survey the business sectors' views of continuing education's contract training programs; and conduct this study over a period of time. It would also be useful to conduct a study of similar sized and type of continuing education contract training program that are also serving similar business sectors, and to examine the views from both the business and higher education perspective.

This research should be replicated to include all sectors of a university that provide training and development to the business community. This might include the schools or departments of business, engineering, health sciences, computer science, and public administration. Gaining a university wide perspective of training activity would further the understanding of higher education's commitment to training and workforce development. A study of this kind would also provide a better measure of higher education's contributions to the development of the local business community.

If interviews were conducted with a sample of small and large contract training programs, a much more detailed understanding could be achieved regarding the effects of size. A clearer sense of some of the attitudes toward contract training programs could 
also be achieved. Understanding the differences may help university continuing education programs take steps to improve their programs and avoid potential barriers.

It would also be important to revise the survey to collect data from businesses currently using continuing education units as training providers. That would provide insight into how continuing education is perceived as a provider, who is the competition for training, what are the barriers, what are the needs, and what are their views of business/higher education partnerships.

This research should become a longitudinal study. Following trends and changes in activity of continuing education's involvement would be a valuable tool for both the business and continuing education communities. A study of this kind would also help inform those organizations interested in establishing collaborative ventures.

Another possibility would be to identify five university continuing education units of similar size and type that are serving similar business sectors. Then, depth interviews could be conducted with both the businesses being served and the continuing education units providing the training, and their perceptions could be compared. This approach would provide a better understanding of how business/higher education relationships evolve and develop. A case study of this type would provide the most holistic view of these types of relationships. Both the business and higher education community would benefit from such an understanding. 


\section{REFERENCES}

Alsanian, C. B. (1988). Partnerships for training: Putting principles into action. In D. R. Powers, M. Powers, F. Betz, \& C. B. Alsanian (Eds.), Higher education in partnership with industry (pp. 243-258). San Francisco: Jossey-Bass.

Anderson, C. M. (1995). Organizational culture and effectiveness in community college and business partnerships. Unpublished doctoral dissertation, University of San Francisco, San Francisco.

Ash, A. M. (1989). Interorganizational relations and effectiveness in school/business partnerships. Unpublished doctoral dissertation, University of Miami, Miami.

Babbie, E. (1990). Survey research methods $\left(2^{\text {nd }}\right.$ ed. $)$. Belmont, CA: Wadsworth.

Ball, J. L. (1994). The role of contract training by academic institutions in corporate education and training programs. Unpublished doctoral dissertation, University of North Texas, Denton.

Ballantyne, C. E. (1985). A model for community colleges to develop business/industry linkages. Unpublished doctoral dissertation, University of Iowa, Iowa City.

Bassi, L., \& McMurrer, D. P. (1998). Training investment can mean financial performance. Training and Development, $\underline{52}$ (5), 37-40.

Bassi, L., \& Van Buren, M. E. (1998). The 1998 ASTD state of the industry report. Training and Development, $\underline{52}(1), 23-43$. 
Beder, H. (1984). Principles of successful collaboration. In H. Beder (Ed.), Realizing the potential of interorganizational cooperation: New directions for continuing education, (no. 23). San Francisco: Jossey-Bass.

Boyer, E. L. \& Hechinger, F. M. (1981). Higher learning in the nation's service. Washington, DC: Carnegie Foundation for the Advancement of Teaching.

Brown, N. J. (Ed.) (1990). Lifelong learning trends: A profile of continuing higher education. Washington, DC: National Continuing Education Association.

Brown, N. J. (Ed.) (1995). The knowledge connection: The role of colleges and universities in workforce development. Washington, DC: National Continuing Education Association.

Burton, L. E. (1992). Developing resourceful humans: Adult education within the economic context. New York: Routledge.

Carnegie Foundation for the Advancement of Teaching (1994). A classification of institutions of higher education. Princeton; author.

Carnevale, A. P., Gainer, L. J., \& Villet, J. (1990). Training partnerships: Linking employers and providers. (Report from the American Society of Training and Development and the U. S. Department of Labor, Employment and Training Administration). Alexandria, VA: American Society of Training and Development. Carnevale, A. P., \& Johnston, J. W. (1989). Training America: Strategies for the nation. (Report from the American Society for Training and Development and the National Center on Education and the Economy). Alexandria, VA: American Society of Training and Development. 
Cervero, R. M., \& Scanlan, C. L. (Eds.) (1985). Problems and prospects in continuing professional education. San Francisco: Jossey-Bass.

Charner, I., \& Rolzinski, C. A. (Eds.) (1987). Responding to the educational needs of today's workplace. San Francisco: Jossey-Bass.

Chmura, T. (1986). The higher education-economic development connection. Emerging roles for public colleges and universities in a changing economy. (Report from the American Association of State Colleges and Universities and the Stanford Research Institute). Washington, DC: American Association of State Colleges and Universities.

Cohen, A. M., \& Brawer, F. B. (1989). The American community college $\left(3^{\text {rd }}\right.$ ed.). San Francisco: Jossey-Bass.

Collier, E. J. (1996). A national study of employment training, education, and development services of community colleges and activities that facilitate and hinder college and industry collaboration. Unpublished doctoral dissertation, George Washington University, District of Columbia.

Cross, P. K. \& McCartan, A. (1984). Adult learning: State policies and institutional practices. (ASHE-ERIC Higher Education Research Report, No. 1). Washington, DC: American Society of Higher Education.

Davis, S., \& Botkin, J. (1994). The monster under the bed. New York: Simon and Schuster.

Digest of Educational Statistics (1997). (Report No. 98-015). Washington, DC: National Center for Educational Statistics.

Drucker, P. F. (1978). The age of discontinuity. New York: Harper and Row. 
Drucker, P. F. (1994). The age of social transformation. The Atlantic Monthly, $\underline{277}(11), 53-80$.

Eurich, N. P. (1989). Corporate classrooms: The learning business.

Lawrenceville, NJ: Princeton University Press.

Fairweather, J. S. (1988). Entrepreneurship and higher education: Lessons for colleges, universities, and industry. (ASHE-ERIC Higher Education Report, No. 6.). Washington: American Society of Higher Education.

Fairweather, J. S. (1989). Academic research and instruction. The Journal of Higher Education, 60 (4), 388-407.

Fenwick, D. C., Giorgio, P. A., Kopecky, R. J., Lloyd, L. G., \& Myers, J. R. (1986). Guide to campus-business linkage programs. New York: Macmillan.

Fowler, F. J. (1988). Survey research methods. Newbury Park, CA: Sage.

Frazis, Harley, Gittleman, Maury, \& Joyce, Mary (1998). Determinants of training: An analysis using both employer and employee characteristics. Report for the U.S. Department of Commerce, Bureau of Labor Statistics. Unpublished, February.

Gehres III, E. D. (Ed.) (1998). Lifelong learning trends: A profile of continuing education $\left(5^{\text {th }} \mathrm{ed}\right)$. Washington, DC: University Continuing Education Association.

Gerlach, J. M. (1992). An analysis of business partnerships in higher education. Unpublished doctoral dissertation, University of North Texas, Denton.

Gexler, S. (1994). A study to determine what makes an effective partnership between community colleges and business. Unpublished doctoral dissertation, San Francisco University, San Francisco. 
Gladden, K. C. (1988). Continuing education in colleges and universities:

Current role and scope and trends. Unpublished doctoral dissertation, Arkansas

University, Fayetteville.

Goldstein, I.L. \& Gillian, P. (1990). Training system issues in the year 2000. American Psychologist, $\underline{45}$ (2), 134-143.

Gordon, E. E., Morgan, R. R., \& Ponticell, J. A. (1994). Future work: The revolution reshaping American business. Westport, CT: Praeger Publisher.

Gore Summit (1999). Summit on $21^{\text {st }}$ century for $21^{\text {st }}$ century jobs. [Online]. Available: http://vpsummit.org. (February 9, 1999).

Green, M. (Ed.) (1997). Transforming higher education: Views from leaders around the world. Phoenix, AZ: Ornyx Press.

Henderson, J. K. (1986). Differences in perception of benefits and liabilities in collaborative relationships between business-industry and higher education. Unpublished doctoral dissertation, University of Houston, Houston.

Iowa State Department of Education (1996). The role of community college adult and continuing education in Iowa's workforce development centers. (Position paper prepared by the Iowa Association of Adult and Education Deans and Directors). Creston, IA: Adult and Continuing Education, Southwestern Community College.

Jacks, L. P. (1931). The education of the whole man: A plea for a new spirit in education. London: University of London Press.

Kerr, C. (1994). Higher education cannot escape history: Issues for the twentyfirst century. Albany, NY: SUNY Press. 
Lawrence, J. D. (1997). Selection factors and need area differences among industry types in selecting providers of customized training and continuing education. Unpublished doctoral dissertation, Auburn University, Auburn.

Lusk, K. (1987). Variables associated with the success of community college business partnerships. Unpublished doctoral dissertation, Claremont Graduate School, Claremont.

Lynch, L. M., \& Black, S. E. (1996). Beyond the incidence of training: Evidence from a national employer survey. Philadelphia: University of Pennsylvania Center on the Education Quality of the Workforce: Working Paper No. 35.

Lynton, E. A. (1984). The missing connection between business and universities. New York: Collier Macmillan Publishers.

Matthews, J. B., \& Norgaard, Rolf (1984). Managing the partnerships between higher education and industry. Boulder, CO.: National Center for Higher Education Management Systems.

Meister, J. C. (1994). Corporate quality universities: Lessons in building a world-class workforce. Chicago: Irwin Professional Publishing.

New England Board of Higher Education (1987). Education and training for the future of New England: A 1987 survey of human resource managers. Boston: New England Board of Higher Education.

Norris, D. M. (1998). Fusion and the knowledge age. NACUBO Business Officer, $\underline{31}$ (5), 36-42. 
Peterson, M. W., \& Dill, D. D. (1997). Planning and management for a changing environment: A handbook on redesigning postsecondary institutions. San Francisco: Jossey-Bass.

Powers, D. R., Powers, M. F., Betz, F., \& Aslanian, C. B. (1988). Higher education in partnership with industry. San Francisco: Jossey-Bass.

Rodenhouse, M. P., \& Torregrosa, C. H. (Eds.) (1998). The 1999 Higher education directory. Falls Church, VA: Higher Education Publications, Inc.

Schmidt, P. (1998, June 19). Governors want fundamental changes in colleges. Question place of tenure. Chronicle of Higher Education, p. A38.

Shoemaker, C. J. (1998). Leadership in continuing and distance education in higher education. Needham Heights, MA: Allyn and Bacon.

Stevens, D. W. (1992). Advancing adult workforce skills: Opportunities and requirements for state action. Philadelphia: University of Pennsylvania Center on the Education Quality of the Workforce: Working Paper No. 2.

Tyson, L. D. (1987). Quality of and equality for our workforce. Presentation at university of continuing higher education forum. (ERIC Document Reproduction Services No. ED 311744 )

U. S. Department of Commerce, Office of Technology (1997). America's new deficit: The shortage of information technology workers. Washington, DC: Author.

U. S. Department of Labor, Bureau of Labor Statistics (1996, July 10). Survey of employer provided training-Employer results. (News Release: 96-268). Washington, DC: Author. 
U. S. Department of Labor, Bureau of Labor Statistics (1996, December 19).

Survey of employer provided training-Employee results. (News Release: 96-515).

Washington, DC: Author.

U. S. Department of Labor, Bureau of Labor Statistics (1997). Charting the Projections: 1996-2006. Occupational Outlook Quarterly, 41(4).

U. S. Department of Labor, Bureau of Labor Statistics (1998). Worker Displacement, 1995-97. (News Release: 98-347). Washington, DC: Author.

University Continuing Education Membership Directory 1996-97 (1996). Washington, DC: University Continuing Education Association.

Veysey, L. R. (1965). The emergence of the American university. Chicago: The University of Chicago Press.

Virginia First 2000 (1997). The Virginia Business Higher Education Council Report. Richmond, VA: Virginia Business Higher Education Council.

Wakefield, J. A. (1992). Training partnerships between businesses and community and technical colleges in Washington state community colleges. Unpublished doctoral dissertation, Seattle University, Seattle.

Wigginton, K. W. (1996). The role of higher education in economic development: An assessment of the economic development activities of higher education institutions in the Commonwealth of Virginia. Unpublished doctoral dissertation, University of Virginia, Charlottesville.

Wilder, N. E. (1988). Effective continuing education relationships between universities and business. Unpublished doctoral dissertation, University of Oregon, Eugene. 
Wolin-DeLuca, C. A. (1991). Contract training in the Virginia community

college system. Unpublished doctoral dissertation, University of Virginia, Charlottesville.

Workforce Investment Act of 1998, H.R. 1385, $105^{\text {th }}$ Cong., $2^{\text {nd }}$ Sess. (1998).

Zemsky, R., \& Oedel, P. (1994). Higher education and the changing nature of the American workforce -responses, challenges, and opportunities. Philadelphia: University of Pennsylvania Center on the Education Quality of the Workforce: Working Paper No. 21. 


\section{APPENDIX A}

\section{CORPORATE CONTRACT TRAINING SURVEY}

For this survey, Corporate Contract Training is defined as contracted credit and non-credit courses, degree programs, workshops, seminars, and training for enhancing the workforce of business and industry that are conducted by your continuing education unit..

For the following questions, please check the appropriate box or boxes as indicated.

\section{University Corporate Contract Training Programs}

1. Does your Continuing Education Unit offer Corporate Contract Training programs?

[] YES
[] NO

If $Y E S$, please complete the entire survey and return it in the self-addressed stamped envelope.

If $N O$, please complete the Organizational Information and Institutional Demographics section on page 5 and return the survey in the self-addressed stamped envelope.

2. Why is your CE unit involved in corporate training?

[] $\mathrm{YES}$

[] NO

3. How are your corporate training programs funded (check one)?

[ ] university budget for continuing education [ ] revenue from corporate contracts only

[] revenue from other programs [] a combination of university and contract resources

[] Other (please describe):

4. In what ways does the university support your corporate training programs (check one)?

[ ] provides financial resources for operations

[] provides physical/capital resources (i.e., space/ equipment)

[] has policies that encourage faculty to participate

[] senior officers participate in initiating and negotiating contracts

[] some combination of the above

[] Other (please describe):

5. What was your corporate contract training revenue in 1998, before subtracting out general university overhead charges?
[ ] $\$ 0-249,999$
[ ] $\$ 250,000-499,999$
[ ] $\$ 500,000-999,999$
[ ] \$1million- 2.49 million
[] \$2.5 million- 4.99 million
[] $\$ 5$ million +

6. Compared to five years ago (1993), your division's revenue from corporate contract training has:
[.] increased significantly
[] decreased some
[ ] increased some
[] decreased significantly
[ ] stayed the same
[] not known 
7. How many corporate contract training programs did you provide to business and industry in 1998?
[ ] $1-10$
[] $11-25$
[ ] 26-50
[ ] $51-100$
[ ] $101+$
[] not known

8. How many staff members (full time equivalent- FTE) are dedicated to the corporate education activity?
[] 0-1 FTE
[] 2-3 FTE
[] 4-5 FTE
[] 6-7 FTE
[] $7+$ FTE

9. What was the estimated number of students enrolled in your department's contract training programs in 1998 ?
[]$<99$
[ ] 100-499
[] 500-999
[ ] 1000-2499
[ ] 2500-4999
[ ] $5000+$

10. In 1998, how far from your main campus were most of your corporate contracttraining clients located?
[ ] 0-49 miles
[ ] 50-99 miles
[] 100-249 miles [] 250 or more miles

11. From the calls and inquiries you receive for corporate contract training programs, what is your estimate of the demand your unit is currently meeting?
[ ] $25 \%$ or less
[] $50 \%$
[ ] $75 \%$
[] $100 \%$
[ ] not known

12. Please describe your level of satisfaction with your corporate training programs, using a $1-5$ scale (1 is LEAST satisfied, 3 is NEUTRAL, and 5 is MOST satisfied) on the following items :
a) financial
b) public relations
c) academic quality
d) program dev. staff

$\begin{array}{lllll}1 & 2 & 3 & 4 & 5 \\ 1 & 2 & 3 & 4 & 5 \\ 1 & 2 & 3 & 4 & 5 \\ 1 & 2 & 3 & 4 & 5\end{array}$

13. Over the next 5 years, do you expect the number of corporate contract training programs to:

[ ] decrease significantly [ ] decrease some [ ] stay the same [ ] increase some [ ] increase significantly 


\section{Corporate Training Characteristics}

14. What types of corporate contract training did you deliver to business and industry in 1998 (see Glossary on p. 6 for definitions and please check all that apply)?

[ ] awareness (i.e., sexual harassment, cultural diversity)

[] basic skills

[] clerical and administrative support

[ ] communications, employee development, and quality

[] computer programming/software

[] health and wellness

[] management/supervision
[] production and construction (i.e., operating machinery)

[] professional/technical

[] occupational safety

[] orientation

[] sales and customer service

[] service-related

[ ] other (please describe):

15. Based on the number of participants, what types of programs were in most demand in 1998 (please check all that apply)?

[ ] awareness (i.e., sexual harassment, cultural diversity)

[] basic skills

[] clerical and administrative support

[] communications, employee development, and quality training

[] computer programming/software

[ ] health and wellness

[ ] management/supervision
[ ] production and construction (i.e., operating machinery)

[ ] professional/technical

[] occupational safety

[ ] orientation

[] sales and customer service

[] service-related

[ ] other ( please describe):

16. From your assessment, what level of employee are you serving most often through your corporate contract training programs (please check one)?
[] administrative/secretarial
[] professional/technical
[ ] executive (VP and above)
[ ] $1^{\text {st }}$ level manager
[] middle manager

[] not known

[] executive( (VP and above)

17. What sector of companies were served by your corporate training services in 1998 (please check all that apply)?
[ ] chemical and petroleum
[] communications
[ ] construction
[] finance
[] health services
[] information technology
[ ] insurance
[] pharmaceutical
[] manufacturing
[ ] utilities
[] publishing
[] mining
[] retail
[ ] transportation
[ ] service (restaurant/hotel/entertainment)
[ ] other

18. Within what sector did you have the highest number of corporate contract training programs in 1998 ?

[] chemical and petroleum[ ] communications [] construction
[] finance
[] health services [] information technology
[] insurance
[] pharmaceutical
[] manufacturing
[] publishing
[] mining
[] utilities
[] conglomerate
[] retail
[] service (restaurant/hotel/entertainment)
[] transportation
[] other 
19. What sector of business yielded the single largest revenue producing corporate training contract in 1998 ?

$\begin{array}{lll}\text { [] chemical and petroleum } & \text { [] communications } & \text { [] construction } \\ \text { [] finance } & \text { [] health services } & \text { [] information technology } \\ \text { [] insurance } & {[] \text { manufacturing }} & \text { [] mining } \\ \text { [] pharmaceutical } & \text { [] publishing } & \text { [] retail } \\ \text { [] utilities } & \text { [] conglomerate } & \text { [] transportation } \\ \text { [] service (restaurant/hotel/entertainment) } & \text { [] other }\end{array}$

20. Based on the number of employees, what size company had the highest number of corporate training contracts with you in 1998 ?
[ ] $0-20$
[ ] 21-49
[ ] 500-999
[ ] $1000-2499$
[] $50-99$
[] $100-499$
[ ] 2500 and above
[] not known

\section{Benefits and Barriers to University Provided Corporate Contract Training}

21. What benefits has the university received from delivering corporate contract training programs (please check all that apply)?

[ ] improved relationship with the business community

[ ] increased revenue for the university

[ ] increased research funding

[] equipment and gifts in-kind from business and industry

[] increased corporate giving to the institution

[] fulfillment of mission

[] increased enrollment in other continuing

education programs
[] increased and enhanced visibility leading to greater internal support from the institution

[ ] opportunity to provide "real world" contact to faculty

[] beneficial public relations for continuing education

[ ] internship opportunities for students

[] student placement

[ ] other (please describe):

22. What barriers limit the institution from delivering corporate contract training to business and industry (please check all that apply)?
[] attitude of top university leadership
[ ] lack of qualified instructors
[] inadequate facilities
[ ] lack of internal support
[ ] lack of time to develop training programs
[] inability to properly market programs

[] attitude of corporate executives

[] time constraints of other programs

[ ] CE not seen as a provider of contract training

[ ] difficulty scheduling courses

[ ] poor coordination by state and federal agencies

[] Other (please describe):

23. Based on your professional observations, what do you see as the most important characteristics that facilitate successful corporate contract training programs between business and university continuing education divisions (please check all that apply)?

\footnotetext{
[ ] talented personnel

[] curriculum development

[] marketing

[] delivery

[] evaluation and follow-up procedures

[ ] previous relationship with business community

[] federal and state grants
}

[ ] internal commitment of financial resources including personnel, equipment and facilities [] involvement of senior level management in program

[] defined processes, systems, and procedures to carry out contract training programs

[ ] Other (please describe): 


\section{Organizational Information and Institutional Demographics}

24. How is your continuing education operation organized?

[ ] academically centralized and administratively centralized

[ ] academically decentralized and administratively centralized

[ ] academically centralized and administratively decentralized

[ ] academically decentralized and administratively decentralized

25. What is the title of your units CEO?
[] Associate Vice Chancellor
[] Vice Provost
[ ] Director
[ ] Associate Vice President
[] Dean
[] Other

26. To whom does the CEO of the CE unit report?
[ ] President
[ ] Provost
[ ] Academic Vice President
[] Vice Provost [] Other

27. In what state is your institution located?

28. What is the undergraduate and graduate enrollment (full time equivalent) at your institution?
[ ] 2500-4999
[ ] 5000-9999
[ ] 10,000-19,999
[ ] 20,000+

29. How is your university described (please check all that apply)?

[] public [] land grant []private [] other

30. How would you describe your institution's location?

[ ] urban [ ] small city (pop. of 100,000 or less) [ ] suburban [ ] rural

31. Based on Carnegie classifications of higher education, how is your institution categorized?

[ ] Research I: 50 or more doctoral degrees each year/ receive 40 million or more in federal support

[] Research II: 50 or more doctoral degrees each year/ 15.5 to 40 million in federal support

[ ] Doctoral I: 40 or more doctoral degrees in five or more disciplines

[ ] Doctoral II: 10 or more doctoral degrees in three or more disciplines or 20 doctorates in one discipline

32. Would you like a copy of the aggregated results? [ ] YES [ ] NO

\section{THANK YOU!}

Please mail your response by December 15, 1999 in the enclosed envelope to: Donald A. Hasseltine, 25 Wellington Circle, Lebanon NH 03766. 


\section{Training Type Glossary ${ }^{1}$}

- $\quad$ Awareness training provides information on policies and practices that effect employee relations (i.e., sexual harassment policies, cultural diversity)

- Basic skills training is training in elementary reading, writing, arithmetic, and English skills.

- Clerical and administrative support skills training is training in areas such as typing, filing, business correspondence, and administrative record keeping and budgeting.

- Communications, employee development, and quality training is training, such as public speaking, office organization, and time management.

- Computer procedures, programming, and software training includes training in computer literacy, security, programming, use of standard and commercial and other software, and methods for developing software applications.

- Employee health and wellness training provides information and guidance on personal health matters.

- Management training is training in supervising and in implementing employment practices. Examples include training in conducting employee appraisals, managing employees, resolving conflicts, and following selection/hiring practices.

- Production and construction related training is training in areas such as operating machinery and equipment; manufacturing, assembling, distributing, installing, or inspecting goods.

- Professional and technical skills training is training in professional areas such as engineering, nursing, accounting, science, law, and medicine.

- Occupational safety training provides information on safety hazards, procedures, and regulations.

- Orientation training introduces new employees to personnel and workplace practices.

- $\quad$ Sales and customer services training is training in areas ranging from how to maintain and improve customer relations to specific selling techniques.

- $\quad$ Service-related training includes training in the traditional service occupations-food, cleaning, and personal services. Examples include training in waiting tables, preparing food, using cleaning equipment, and providing care for children.

\footnotetext{
${ }^{1}$ Bureau of Labor Statistics (1996, July 10). Report on the amount of employer-provided formal training. [On-line]. Available ftp://146.142.4.23/pub/news.release/sept1.txt (September, 1998).
} 


\section{APPENDIX B}

\section{Operational Table}

Research Questions:

Survey Items:

1. Are corporate workforce development activities an accepted part of the continuing education unit's mission? 1,2

2. What financial support does the university provide for corporate workforce development programs (i.e., are corporate workforce development programs expected to be selfsufficient?)

3. How many staff members are dedicated to corporate contract training activities?

4. How much revenue is produced by corporate contract training programs?

5. Are continuing education units' corporate training programs serving local, regional, national, and international interests?

6. Are continuing education units satisfied with their corporate contract training programs?

7. What types of corporate training programs (management, technical, remedial, developmental, etc.) do continuing education units offer?

8. What type of training program is most commonly requested by business and industry? 
9. What level of employee is most often served by continuing education units' training programs?

10. How many total corporate contract programs are offered each year by continuing education units?

11. What size companies are seeking corporate training services?

12. What types of businesses (i.e., insurance, finance, and technology) are seeking workforce development services?

13. Are continuing education units' involvement in corporate contract training programs increasing or decreasing?

14. What was the 1998 enrollment in continuing education units' sponsored corporate contract training?

15. What benefits does the university derive from offering workforce training programs to business and industry?

16. What problems and barriers limit universities from providing workforce development programs?

17. What characteristics facilitate effective corporate contract training programs between business and higher education? 


\title{
APPENDIX C
}

\section{Cover letter to Participate in the Survey}

\author{
Dr. Andy DiPaola \\ Executive Dir. Professional Development \\ Stanford University \\ Stanford, CA 94305-2051
}

Dear Dr. DiPaola:

November 1,1999

The attached survey seeks information pertaining to how your unit is participating as a provider of corporate training and development. This research project represents the first time that the role of university continuing education in corporate training is being examined and is being conducted as part of my Ph.D. work in higher education administration at the University of Virginia.

The purpose of this study is to gather information that may lead to a better understanding of higher education's unique role as a provider of corporate training. It is also intended to help you gain a better understanding of what sectors of business are interested in your services, the kinds of training being sought, and the level of staff employee being trained. The survey also explores what facilitates and limits institutions from building business training and development partnerships.

Carnegie classified doctoral-granting institutions $(\mathrm{N}=236)$ serve as the research sample for this project. The small sample size makes each participant vitally important to the quality and success of this project. The thirty-one, closed-ended question survey took my pilot-study group about 20 minutes to complete. Your time commitment may differ depending on the availability of corporate training data.

Your responses will be kept completely confidential and the results will be reported only as an aggregated population sample. The survey has been coded to assist with the mailing-response process only. The number (in the upper right-hand corner of the survey) will be used to track the return of the surveys and help to avoid unnecessary follow-up contact with you.

As a participant in this study, you are entitled to receive a copy of the information gathered from this research. Please indicate your desire to receive a copy of the results by checking "YES" on question 32 . If you have any questions, please contact me at (603) 526-3442.

Sincerely,

Donald A. Hasseltine

Doctoral Candidate

PS. This project has received the encouragement and endorsement of Ted Settle, Director of Continuing Education at Virginia Polytechnic Institute and State University and Chair of Region III and UCEA's Commissioner, Futures \& Markets; Doreen Maxcy, Assistant Dean of Continuing Education at Louisiana State University and UCEA's Co-Commissioner, Research; and Wendell Smith, Vice President of External Affairs, University of Missouri, St. Louis and the incoming president of UCEA. 


\section{APPENDIX D}

\section{Follow up Letter and Email}

Dear Dr. Kelly:

I am writing in reference to a survey entitled CORPORATE CONTRACT TRAINING, which I am hoping you received from me earlier this month. I am a doctoral student at the University of Virginia, and am using the survey to collect data for my dissertation.

I am very excited to be one of the first to examine university continuing education's involvement in corporate contract training and development, and have been heartened that many of your colleagues have responded so positively to the project. The study becomes increasingly more valuable and robust with every returned survey. The small sample size of 200 also makes each participant's response very important and valuable to the research project. I hope you will join with your other colleagues and complete the survey. I have targeted a response rate of $50 \%$, and though the return rate has been encouraging, it has still fallen short of this initial goal. Your completion of the survey is crucial to my research, and I am eager to find out how your continuing education unit handles this function.

The survey takes approximately 20 minutes to complete. I have attached another copy for your use if you did not get the initial mailing. A response by December 15,1999 would be greatly appreciated. My goal is have all the data collected and analyzed by the New Year, and the study completed by this spring. I thank you for your time, interest, and support.

Sincerely,

Donald A. Hasseltine

PS. My apologies if this email and your completed survey have crossed in the "mail" - I look forward to receiving it. 


\section{APPENDIX E}

\section{Participating Institutions}

1. Adelphi University

2. American University

3. Andrews University

4. Arizona State University

5. Auburn University

6. Ball State University

7. Baylor University

8. Boston College

9. Boston University

10. Bowling Green State University

11. Brandeis University

12. Brigham Young University

13. Brown University

14. Case Western Reserve University

15. Catholic University of America

16. Clark Atlanta University

17. Clark University

18. Clarkson University

19. Clemson University

20. Cleveland State University

21. Colorado School of Mines

22. Colorado State University

23. Columbia University

24. Cornell University

25. DePaul University

26. Drexel University

27. Duke University

28. Duquesne University

29. Florida Atlantic University

30. Florida International Univ.

31. Florida State University

32. George Mason University

33. George Washington University

34. Georgetown University

35. Georgia State University

36. Harvard University

37. Howard University

38. Idaho State University

39. IN Univ.-Purdue Univ. Indianapolis

40. Indiana State Univ.

41. Indiana University Bloomington 
42. Indiana University of Pennsylvania

43. Iowa State University

44. Johns Hopkins University

45. Kansas State Univ.

46. Kent State University

47. Lehigh University

48. Louisiana State Univ. \& A\&M Coll.

49. Louisiana Tech University

50. Loyola University of Chicago

51. Marquette University

52. Massachusetts Institute of Technology

53. Miami University

54. Michigan State University

55. Middle Tennessee State University

56. Mississippi State University

57. Montana State University-Bozeman

58. New Mexico State University

59. New School University

60. New York University

61. North Carolina State University

62. North Dakota State University

63. Northeastern University

64. Northern Arizona University

65. Northern Illinois University

66. Northwestern University

67. Ohio State University

68. Ohio University

69. Oklahoma State University

70. Old Dominion University

71. Oregon State University

72. Pennsylvania State University

73. Pace University

74. Portland State University

75. Purdue University

76. Rutgers State University--New Brunswick

77. San Diego State University

78. Seton Hall University

79. Southern Illinois University Carbondale

80. Southern Methodist University

81. St. John's University

82. St. Louis University

83. Stanford University

84. SUNY at Albany

85. SUNY at Binghamton

86. SUNY at Buffalo 
87. SUNY at Stony Brook

88. Syracuse University

89. Temple University

90. Tennessee State University

91. Texas A\&M Univ.-Commerce

92. Texas A\&M University

93. Texas Christian University

94. Texas Southern University

95. Texas Tech University

96. Texas Woman's University

97. Tufts University

98. Tulane University

99. University of Akron

100. University of Alabama

101. University of Alabama at Birmingham

102. University of Alabama in Huntsville

103. University of Alaska Fairbanks

104. University of Arizona

105. University of Arkansas at Fayetteville

106. University of California, Berkeley

107. University of California, Davis

108. University of California, Irvine

109. University of California, Los Angeles

110. University of California, Riverside

111. University of California, San Diego

112. University of California, Santa Barbara

113. University of California, Santa Cruz

114. University of Central Florida

115. University of Chicago

116. University of Cincinnati

117. University. of Colorado at Boulder

118. University of Colorado at Denver

119. University of Connecticut

120. University. of Delaware

121. University of Denver

122. University of Florida

123. University of Georgia

124. University of Hawaii at Manoa

125. University of Houston

126. University of Idaho

127. University of Illinois at Chicago

128. University of Illinois Urbana-Champaign

129. University of Iowa

130. University of Kansas

131. University of Kentucky--Lexington Camp. 
132. University of Maine

133. University of Maryland Baltimore County

134. University of Maryland College Park

135. University of Massachusetts at Amherst

136. University of Massachusetts Lowell

137. University of Memphis

138. University of Miami

139. University of Michigan

140. University of Minnesota--Twin Cities

141. University of Mississippi

142. University of Missouri--Columbia

143. University of Missouri--Kansas City

144. University of Missouri--Rolla

145. University of Missouri--St. Louis

146. University of Montana--Missoula

147. University of Nebraska--Lincoln

148. University of Nevada--Reno

149. University of New Hampshire

150. University of New Mexico

151. University of New Orleans

152. University of North Carolina Chapel Hill

153. University of North Carolina Greensboro

154. University of North Dakota

155. University of North Texas

156. University of Northern Colorado

157. University of Notre Dame

158. University of Oklahoma

159. University of Oregon

160. University of Pennsylvania

161. University of Pittsburgh

162. University of Rhode Island

163. University of San Diego

164. University of San Francisco

165. University of South Carolina--Columbia

166. University of South Dakota

167. University of South Florida

168. University of Southern Mississippi

169. University of Southwestern Louisiana

170. University of Tennessee, Knoxville

171. University of Texas at Arlington

172. University of Texas at Austin

173. University of the Pacific

174. University of Toledo

175. University of Tulsa

176. University of Utah 
177. University of Vermont

178. University of Virginia

179. University of Washington

180. University of Wisconsin--Madison

181. University of Wisconsin--Milwaukee

182. University of Wyoming

183. Utah State University

184. Virginia Commonwealth University

185. Virginia Polytechnic Institute \& State University

186. Wake Forest University

187. Washington State University

188. Washington University

189. Wayne State University

190. West Virginia University

191. Western Michigan University

192. Wichita State University

193. William Marsh Rice University

194. Worcester Polytechnic Institute

195. Wright State University

\section{Non-Participating Institutions}

1. Allegheny University, Health Sciences

2. Biola University

3. California Institute of Technology

4. Carnegie Mellon University

5. Claremont Graduate University

6. College of William \& Mary

7. Dartmouth College

8. Emory University

9. Florida Institute of Technology

10. Fordham University

11. Georgia Institute of Technology

12. Graduate School \& University Center

13. Hofstra University

14. Illinois Institute of Technology

15. Illinois State University

16. Loma Linda University

17. Michigan Technological University

18. New Jersey Institute of Technology

19. Pepperdine University

20. Polytechnic University

21. Princeton University

22. Rennsalear Polytechnic Institute

23. Rutgers State University-Newark 
24. Stevens Institute of Technology

25. SUNY College of Environmental Science

26. Teachers College of Columbia University

27. U.S. International University

28. Union Institution

29. University of California, San Francisco

30. University of Detroit, Mercy

31. University of La Verne

32. University of Louisville

33. University of Rochester

34. University of Southern California

35. University of Texas at Dallas

36. Vanderbilt University

37. Yale University

38. Yeshiva University 


\section{APPENDIX F}

Dear Dr. Settle,

\section{Letter Inviting Pilot Study Participants}

Phillip Robinson from UCEA suggested that I write to ask for your assistance. I am currently conducting my dissertation research on the role of university continuing education in providing workforce development and training to business and industry. To ensure the quality and validity of my survey instrument, I need to conduct a pilot study with experts in the field. I am asking you and four other continuing education professionals to participate in a review of the attached survey instrument. The review includes completing the survey and providing feedback on how long it took to complete, the ease or difficulty in filling it out, were the questions clear and the language appropriate to the field, can the questions be answered, and overall, whether the survey addresses the research question.

This process is very important to a quality project and hope you will agree to participate. If you agree to be involved, I am attending the January 14-15 workforce development conference in Washington D.C. and would like to discuss your assessment sometime during those two days. I will follow-up with you later this week. Thank you for your consideration.

Sincerely, 


\section{APPENDIX G}

\section{Workforce Development Survey Comments}

Please use the questions below as a guide in your assessment of the survey. NAME OF PILOT STUDY PARTICIPANT:

1. Time to complete:

2. Do you think the length of the survey will prohibit participants from filling it out?

3. What recommendations do you have about the organization of the survey? Did the sections make sense and progress logically?

4. Which questions did you struggle to answer? Please explain.

5. What recommendations would you make about the survey's style, tone, and language?

6. If sent to your office, who would most likely fill-out the survey?

7. Are there any key questions that are missing or questions that could be eliminated?

8. Overall, do you think the data collected from the survey will allow me to assess the current role of university continuing education in providing workforce development to business and industry? 